Instituto de Biociências

Universidade de São Paulo

\title{
Anatomia comparada do gênero Doris (Mollusca, Nudibranchia, Dorididae) do litoral brasileiro
}

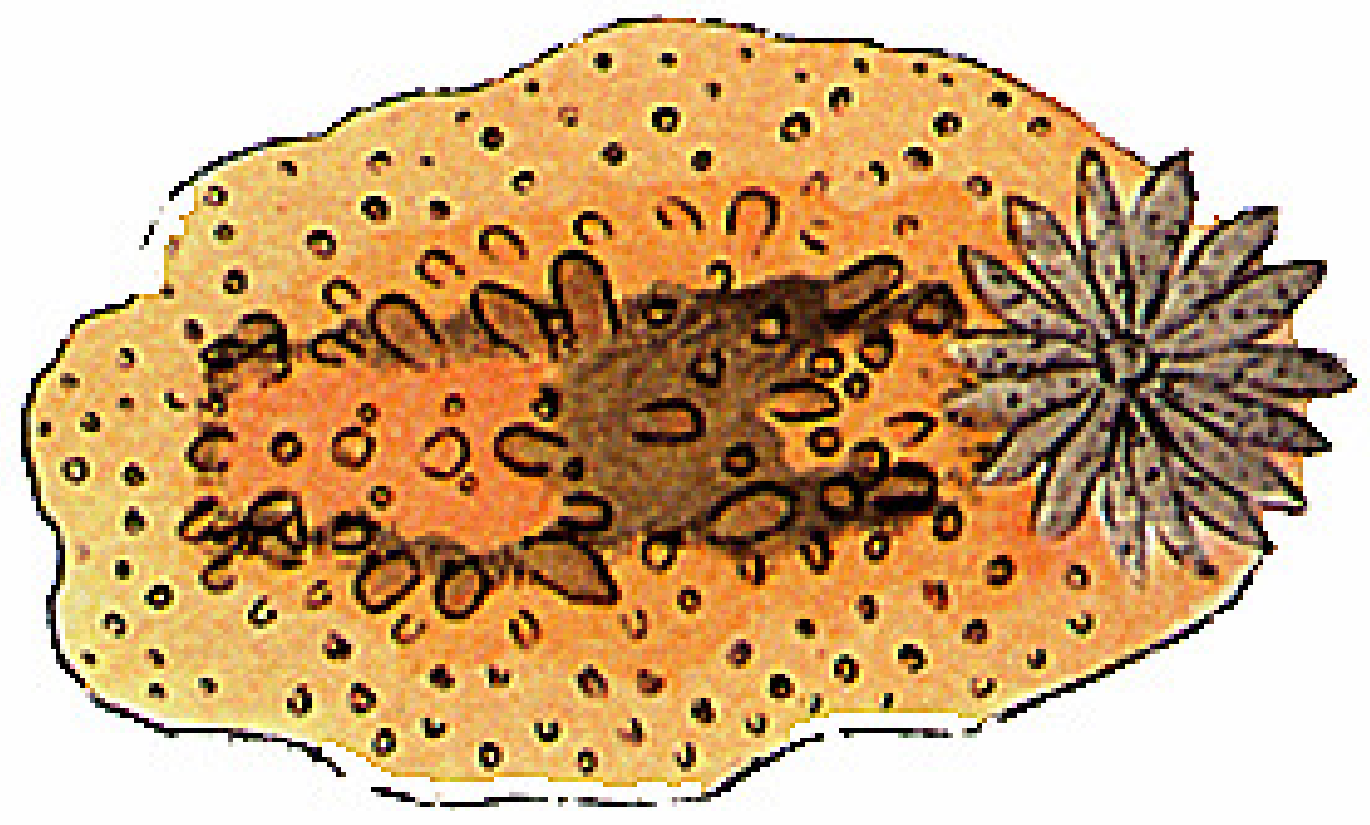

Aluno: Patrícia Oristanio V. Lima

Orientador: Luiz Ricardo L. Simone

Agosto de 2012

São Paulo 


\section{Anatomia comparada do gênero Doris (Mollusca, Nudibranchia, Dorididae) do litoral brasileiro}

\section{Comparative anatomy of genus Doris (Mollusca, Nudibranchia, Dorididae) of Brazilian coast}

Dissertação apresentada ao Instituto de Biociências da Universidade de São Paulo, para a obtenção de Título de Mestre em Zoologia, na Área de Malacologia.

Orientador: Dr. Luiz Ricardo L. Simone.

São Paulo

2012 
Lima, Patricia Oristanio Vaz de

Anatomia comparada do gênero Doris (Mollusca, Nudibranchia, Dorididae) do litoral brasileiro.

Dissertação (Mestrado) - Instituto de Biociências da Universidade de São Paulo. Departamento de Zoologia.

1. Doris 2. Anatomia comparada 3. Dorididae 4. Litoral brasileiro. I. Universidade de São Paulo a. Instituto de Biociências. Departamento de Zoologia.

Comissão Julgadora:

Prof. Dr.

Prof. Dr.

Prof. Dr. Luiz Ricardo L. Simone

Orientador 
Aos meus avós, Giuseppe e Rosa, por todo apoio que sempre me deram desde que me entendo por gente. 
Asfalto e Sal

$\mathrm{O}$ asfalto que te conta história,

A toalha de sal que segura mais uma gota do mar

Depois de um mergulho para refrescar.

Trago junto o que de bom conservo

No peito um amor, na mão a rosa.

Que mais, que posso querer?

Se tenho as memórias para abastecer.

E vou, eu vou lhe conservar no sal, no sal do meu mar.

Céu 
Agradecimento

Ao Prof. Dr. Luiz Ricardo Lopes de Simone, por me aceitar como sua aluna, e encarar esse desafio junto comigo. Por sua confiança em mim, por seus ensinamentos que vieram bem antes desse mestrado, quando eu era sua estagiária. Obrigada por essa oportunidade que me tornou uma profissional de verdade.

A agência de fomento, CNPq e ao Departamento da Pós-Graduação de Zoologia, do Instituto de Biociências/USP, por financiarem essa pesquisa e ao Museu de Zoologia da USP, instituição que me propiciou um espaço físico para desenvolver meu trabalho.

Aos meus familiares, minha mãe, Regina, que mesmo longe fisicamente, sempre me apoiou e se preocupou em saber como estava o meu trabalho. Meu pai Jair, que também não tão próximo fisicamente, sempre quis saber como eu estava com a minha pós-graduação. Aos meus irmãos, Rodrigo e Bárbara, que sempre se orgulharam da irmã mais velha estudar tanto. Principalmente aos meus avós, Giuseppe e Rosa (madame), que estiveram, física e emocionalmente, ao meu lado, me apoiando em todas as decisões que eu tomei para seguir na carreira de bióloga.

Ao meu amigo, companheiro, namorado, Daniel Abbate, que passou junto comigo por todas as etapas dessa pós-graduação, desde as provas da Zoologia e inglês, até a entrega da dissertação na secretaria da pós. Obrigada pela paciência nos meus momentos de tensão...que não foram poucos...Te amo muito!!!

Ao meu amigo, colega de trabalho e um excelente profissional, Dr. Carlo Magenta, que acreditou na minha capacidade, esteve sempre à disposição para me ajudar, com seu conhecimento sobre o grupo, com a troca de artigos científicos muito utilizados neste. 
Ao amigo e especialista em nudibrânquios, Vinícius Padula, pelo incentivo em trabalhar com essas espécies, que nunca ninguém se atreveu, e por contribuir com o depósito, na coleção malacológica (MZSP), de diversos lotes que foram utilizados nesse trabalho.

Ao Prof. Dr. Lucas Cervera (Universidad de Cádiz), pelo envio de um material fundamental para essa dissertação.

Ao Dr. Colin Redfern (Florida Museum of Natural History) pelo envio de material para o estudo.

Ao Prof. Dr. Franklin Noel (Guriri), pelas viagens em busca de material para a minha dissertação: Espírito Santo, Cabo Frio, Búzios, Arraial do Cabo, Ilha Bela.

Ao Prof. Dr. Alexandre Pimenta, pelo empréstimo de material da Coleção Malacológica do Museu Nacional do Rio de Janeiro.

Aos profissionais dos laboratórios de Microscopia Eletrônica de Varredura, Lara (MZSP) e Philipi (IB/USP), pela realização das fotos de estruturas fundamentais para a comparação entre as espécies estudadas.

As minhas amigas e colegas de trabalho, Anita, Vavá e novamente meu namorado, Daniel, que se dispuseram algumas vezes a encarar a incansável busca pelas Doris. Obrigada pela paciência de encarar coletas diurnas e noturnas!!

Aos colegas de laboratório, Eric, Potter, Portuga, Salvador, Bárbara, Jaime, Fontenelle, Vivinha, Ciba, Cuca, onde cada um, à sua maneira, me apoiou muito no decorrer desses dois anos. 


\section{Sumário}

1. INTRODUÇÃ

1.1. Histórico do gênero Doris .......................................................................... 14

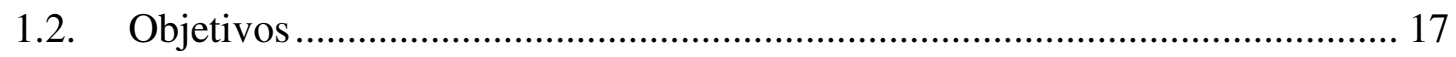

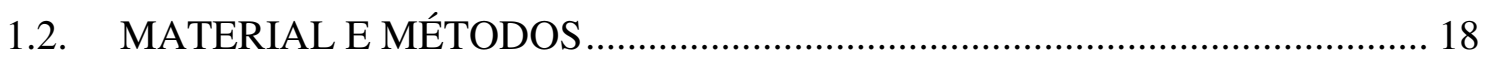

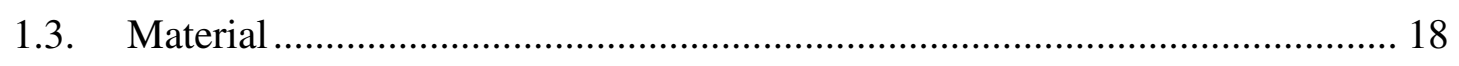

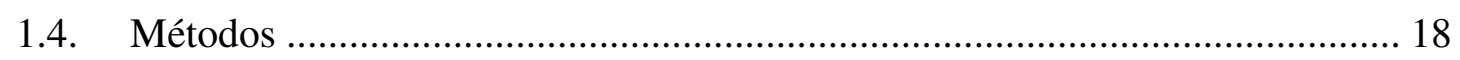

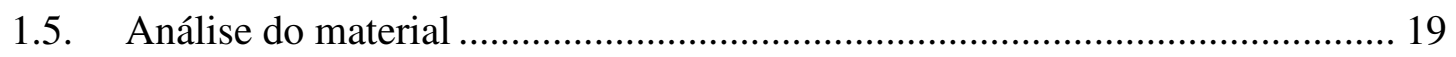

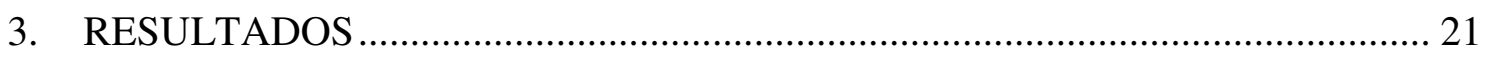

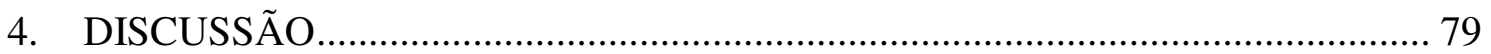

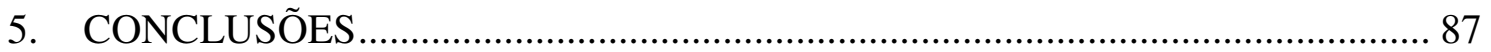

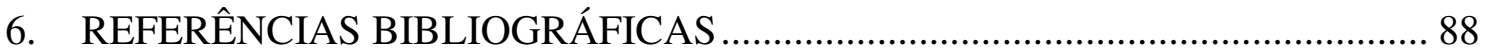




\section{RESUMO}

O gênero Doris está representado no Brasil por quatro espécies: Doris verrucosa, Doris bovena, Doris ilo e Doris kyolis, a maioria delas com um histórico taxonômico confuso. Através da revisão taxonômica do gênero Doris, do estudo da anatomia comparada entre as espécies e com dados da literatura foi possível separar D. verrucosa em duas espécies, mantendo D. verrucosa como a espécie com distribuição para a Europa e Mar Mediterrâneo e Doris januarii, um sinônimo revalidado, com distribuição para a costa Atlântica brasileira. Também foi possível confirmar e completar as informações sobre a anatomia de D. bovena, D. ilo e D. kyolis. As principais características anatômicas que corroboram a distinção entre as espécies estudadas foram encontradas no odontóforo, rádula, sistema reprodutor e sistema nervoso.

Palavras chave: Doris, anatomia comparada, costa Atlântica brasileira. 


\begin{abstract}
The genus Doris in Brazilian shelf is represented by four species: Doris verrucosa, Doris bovena, Doris ilo e Doris kyolis. This species have a misunderstood taxonomy. In this study was carried out a taxonomy revision, utilizing comparative anatomy and previous literature data. As a result, was possible to separate $D$. verrucosa in two species, maintaining D. verrucosa with distribution to Europe and Mediterranean Sea, whereas Doris januarii, a revalidated synonym, is restricted in Brazilian Atlantic coast. In addition, anatomical data complementary validates the species status of $D$. bovena, D. ilo e D. kyolis. The distinctive anatomical characteristics that justify the separation among these species are found in the following structures: odontophore, radula, reproductive system and nervous system.
\end{abstract}

Key-words: Doris, comparative anatomy, Brazilian Atlantic coast. 


\section{INTRODUÇÃO}

Nudibranchia é a maior e a mais diversa ordem de Heterobranchia e constitui um grupo com mais de 3000 espécies conhecidas, a maioria variando entre 10 e $30 \mathrm{~mm}$ de comprimento e com maior representação nos mares tropicais (Willan \& Coleman, 1984; Wägele \& Willan, 2000; Wägele, 2004).

Os nudibrânquios são caracterizados pela perda da concha e opérculo e expansão simultânea do noto sobre a superfície dorsal do corpo durante a fase larval, presença de papilas no noto, detorção tão extensa que resulta em uma completa simetria bilateral virtual externa, cabeça distinta do pé, par de tentáculos orais, um par de estruturas químiossensoriais localizado na região anterior dorsal (rinóforos), sistema reprodutor hermafrodita com maturação simultânea de gametas, fertilização cruzada envolvendo cópula (Thompson, 1976). Os órgãos respiratórios estão na superfície dorsal do corpo e consistem em um círculo de brânquias perianal ou apresenta estruturas denominadas ceratas (Willian, 1998b; Rudman, 1998; Schrödl et. al., 2010).

O corpo mole é protegido por elaboradas defesas morfológicas (espículas e nematocíctos capturados de cnidários), químicas (utilização direta das toxinas de suas presas e síntese de toxinas de fluídos repugnatórios) e comportamentais (autotomia e comportamento críptico). São animais predadores, as dietas consistem de diferentes grupos de animais como Porifera, Cnidaria, Bryozoa, Crustacea, Mollusca, Ascidiacea, com alguns grupos se mostrando bem específicos quanto à preferência pela alimentação (Wägele \& Willan, 2000).

Nudibranchia está dividida nos seguintes clados: Antobranchia, compreendendo Doridoidea, com indivíduos que apresentam um círculo de brânquias ao redor do ânus, na região posterior e Cladobranchia, abrangendo os representantes que apresentam o 
ânus na lateral direita do corpo e papilas dorsais usadas como brânquias secundárias (Wägele \& Willan, 2000; Wägele et. al., 2008).

Entre todas as superfamílias de Nudibranchia, Doridoidea é a que apresenta a maior abundância de representantes, cerca de 2000 espécies descritas (Valdés, 2004), com grande diversidade morfológica e um histórico taxonômico muito confuso. É um táxon chave para estudos sobre a evolução de defesas químicas, padrões de coloração, especialização alimentar no ambiente marinho e taxonomia (Gosliner \& Behrens, 1990; Avila, 1995; Cimino et al., 1999; Valdés, 2001, 2004; Wägele \& Klussmann-Kolb, 2005; Wägele et al., 2008).

Na filogenia publicada por Wägele \& Willan (2000) foram encontradas quatro sinapomorfias de Doridoidea: esôfago sem nenhum revestimento cuticular; sistema reprodutor "triaulico", com três aberturas: oviduto, vagina e pênis; glândula de sangue situada após o sistema genital ou sobre o complexo cérebro-pleural (sistema nervoso) e presença de glândula branquial.

Os representantes da superfamília Doridoidea são divididos em dois táxons, Cryptobranchia, incluindo a família Dorididae, e Phanerobranchia. A principal distinção entre ambas é a presença de uma cavidade para retrair a brânquia, presente nos criptobrânquios e ausente nos fanerobrânquios (Odhner, 1934; Valdés \& Gosliner, 1999; Valdés, 2002; Pola et. al., 2007; Pola \& Gosliner, 2010).

A primeira classificação abrangendo os doridídeos criptobrânquios foi publicada por Bergh (1891) e dividia esse grupo em 10 subfamílias. No decorrer da história taxonômica deste grupo diversos autores propuseram classificações discordantes onde, aproximadamente 15 ou 16 famílias são aceitas, mas muitas contendo um ou poucos gêneros (e.g., Pelsenner, 1906; Iredale \& O’Donoghue, 1923, Odhner, 1934, 1939; 
Thompson, 1976; Schmekel \& Portmann, 1982; Schmekel, 1985; Rudman, 1998; Wägele \& Willan, 2000; Valdés, 2002).

Segundo Valdés (2002) o monofiletismo de Cryptobranchia está baseado em cinco sinapomorfias: presença de um lábio; brânquias dorsais e retráteis (quando presentes); cavidade ao redor do ânus; redução do número de músculos do tubo oral e do odontóforo; e prostata diferenciada. Além de dividir os doridídeos criptobrânquios nos grupos Labiostomata e Porostomata, ambos monofiléticos.

Labiostomata agrupa as famílias: Dorididae, Actynocyclidae, Chromodorididae e Discodorididae, e é sustentado pelas seguintes sinapomorfias: presença de rádula e armadura labial, área da boca bem desenvolvida, pequenos tentáculos orais e glândula de sangue situada em frente ao sistema nervoso central (Valdés, 2002). Porostomata agrupa o restante dos doridídeos criptobrânquios pertencente às famílias Phyllidiidae, Dendrodorididae e Mandeliidae e o monofiletismo deste grupo é baseado na ausência de rádula, área da boca reduzida a um poro, abertura da boca movida posteriormente, ausência da cutícula labial, glândula salivar ausente, glândulas orais presentes, ceco ausente, intestino reduzido e comissura pedal curta. Todas essas estruturas são provavelmente ligadas à alimentação especializada dos Porostomata (Valdés \& Goslines, 1999).

A família Dorididae está representada por, aproximadamente, 130 espécies no mundo (Wägele, 2004) que variam em tamanho com espécies de 2 ou $3 \mathrm{~mm}$ até $200 \mathrm{~mm}$ de comprimento (Kay \& Young, 1969). O corpo é oval, achatado, com a borda do notum se extendendo além do pé, parecido com uma saia. Os rinóforos são lamelares, retráteis em uma cavidade que pode, além de ser lisa ou pustulada, apresentar papilas ao redor da sua margem. As brânquias, localizadas na região medio-dorsal posterior, são 
normalmente tripinadas e retráteis em uma cavidade comum, que abriga também a papila anal (Rudman, 1998).

De acordo com Valdés (2002), Dorididae é monofilética baseado na presença de um pequeno e curto prolongamento oral em ambos os lados da área da boca, e cutícula labial lisa.

Para Dorididae, Odhner (1968) considerava duas subfamílias: Doridinae, com os gêneros Doris Linnaeus, 1758, Austrodoris Odhner, 1926 e Siraius Marcus, 1955, e Artachaeinae, com Artachaea Bergh, 1880 e Alloiodoris Bergh, 1904.

\subsection{Histórico do gênero Doris}

Diversos autores aplicaram o nome Doris verrucosa erroneamente, através de uma descrição baseada em outros trabalhos (Linnaeus, 1758), aplicando o nome $D$. verrucosa para espécies distintas desta, como Pennant (1777) que aplicou o nome para Onchidoris bilamellata (Linnaeus, 1767), ou baseados em distribuição geográfica, onde uma espécie européia não deveria ser a mesma que uma indo-pacífica (e.g. Rapp, 1827; Fischer, 1867) e ainda novos gêneros foram descritos baseados também na distribuição. d'Orbigny, 1839 subdividiu o genero Doris em alguns grupos de diferentes espécies, realocando as espécies Doris bertheloti e D. verrucosa no gênero Doridigitata. Gray (1847) considerou, por designação subsequente, Doris verrucosa como a espécie-tipo de Doridigitata.

O genero Staurodoris Bergh, 1878a foi descrito para substituir Doridigitata, uma vez que o autor considerava este um nome impróprio, porém manteve $D$. verrucosa como a espécie-tipo do gênero. Dessa forma estes dois gêneros se tornaram sinônimos (Valdés, 2002). 
De acordo com Bouchet \& Valdés (2000), Doris verrucosa é uma espécie taxonomicamente reconhecida por diversos autores (e.g. Marcus \& Marcus, 1967; Schmekel, 1968; Schmekel \& Portmann, 1982; Thompson \& Brown, 1984; Just \& Edmunds, 1985), com distribuição da costa Atlântica Européia, Mar Mediterrâneo até as Ilhas Canárias e Altlântico Ocidental (e.g. Marcus, 1955; Franz, 1970; Valdés, 2002, 2006; Garcia et. al., 2008).

Para o Brasil, já foram reportadas Doridigitata derelicta Fischer, 1867, para a costa de Santa Catarina e Staurodoris januarii Bergh, 1878, descrita para o Rio de Janeiro. Ambas sinonimizadas como Doris verrucosa (Marcus, 1957).

Marcus (1955) descreveu o gênero Siraius baseado em apenas um exemplar, abribuído a Siraius ilo Marcus, 1955 com localidade-tipo em São Sebastião, São Paulo, Brasil. De acordo com o autor a espécie se diferenciava de outras espécies, como Etidoris ladislavii Ihering, 1886, e outros gêneros como Doris, Actinocylus Ehrenbergh, 1837, Hallaxa Eliot, 1909 e Austrodoris, por apresentar rádula com dente lateral em forma de gancho e o marginal pectinado, tentáculos orais curtos, espessos e sulcados, glândulas salivares curtas e largas, próstata tubular e pênis desarmado, sem espinhos. Além de descrever esse novo gênero. Neste trabalho Marcus também registra um nova espécie para o gênero Doris no Brasil, Doris bovena Marcus, 1955.

Marcus (1958b) e Marcus \& Marcus, 1970, estendem a distribuição de D. ilo para Cabo Frio/RJ e Trinidad e Tobago, respectivamente. Marcus \& Marcus, 1963 ampliaram a distribuição de D. bovena para Aruba e Curaçao, no Caribe.

Marcus \& Marcus, (1967) descreveram uma nova espécie, Doris kyolis, originalmente descrita também para o gênero Siraius, e com localidade-tipo: MacArthur Causeway, Biscayne Bay, Florida, EUA. 
Baba (1998) considera Siraius como um gênero distinto dos outros pela presença do dente lateral externo pectinado.

A última classificação baseada em uma análise morfológica e filogenética, proposta por Valdés (2002), considera para Cryptobranchia, apenas oito famílias, entre elas Dorididae. Para esta família foram considerados seis gêneros válidos: Doris Linnaeus, 1758; Aldisa Bergh, 1878; Aphelodoris Bergh, 1878; Conualevia Collier \& Farmer, 1964; Pharodoris Valdés, 2001; e Goslineris Valdés, 2001. Ainda neste trabalho, o autor propõe uma considerável mudança na classificação, sinonimizando os gêneros Doriopsis Pease, 1860, Archidoris Bergh, 1878, Anoplodoris Fischer, 1883, Ctenodoris Eliot, 1907, Austrodoris Odhner, 1926, Guyonia Risbec, 1928, Neodoris Baba, 1928, Siraius Marcus, 1955 e Doriorbis Kay \& Young, 1969 com o gênero Doris. Baseando-se na pouca diversificação e a falta de monofilia entre os gêneros citados, confirmando assim a necessidade de uma futura análise filogenética em nível de espécies.

Garcia, et. al. (2008) publica o primeiro registro no Brasil de Doris kyolis, para Fernando de Noronha/PE e Búzios/RJ e Doris pickensi Marcus \& Marcus, 1967 para Búzios/RJ.

Em razão da confusão taxonômica supracitada, o presente estudo, foi idealizado para responder, através de detalhada morfologia comparada, as perguntas: o que é Doris? Qual sua definição taxonômica? E quais as espécies pertencentes a esse gênero que ocorrem no Brasil? Como resultados secundários, o presente estudo também serve para a melhor compreensão da biologia e anatomia desse táxon. 


\subsection{Objetivos}

1. Realizar um estudo anatômico comparativo de representantes de espécies do gênero Doris.

2. Realizar uma revisão taxonômica das espécies pertencentes ao gênero Doris que ocorrem no Brasil.

3. Verificar a ocorrência de Doris verrucosa no Brasil. 


\subsection{MATERIAL E MÉTODOS}

\subsection{Material}

A maior parte do material examinado foram aqueles que já estavam previamente depositados na Coleção Malacológica do Museu de Zoologia/USP (MZSP). Adicionalmente, foram obtidos empréstimos de amostras da coleção do Museu Nacional do Rio de Janeiro, Brasil (MNRJ); Florida Museum of Natural History, Flórida, Estados Unidos (FMNH) (Dr. Colin Redfern). Exemplares de Doris verrucosa foram enviados como doação pela Universidade de Cádiz, Espanha (Dr. Lucas Cervera). Não foi possível analisar a espécie Doris pickensi, por falta de exemplares disponíveis em coleções.

Para cada espécie estudada, a lista completa do material examinado está arranjada antes das descrições de cada espécie.

\subsection{Métodos}

Coletas foram realizadas na zona de intermarés, no período de maré baixa, através do método de catação. Os animais coletados foram mensurados, fotografados e examinados in vivo, a fim de registrar informações sobre a morfologia externa e coloração, uma vez que, depois de fixados, esses animais perdem a coloração e algumas estruturas são retraídas. Posteriormente os exemplares foram anestesiados através de resfriamento em freezer por tempo variável, de 03-10 minutos, ou anestesiados com Cloreto de Magnésio adicionado à água do mar, na sequencia, os exemplares foram fixados em álcool 70\%. 


\subsection{Análise do material}

Os exemplares foram comparados anatomicamente entre si e com os dados da literatura.

As dissecções foram realizadas sob uma lupa estereoscópica, modelo Zeiz Stemi SV 06 e SV 11, com objetivas de 0,4, 0,63 e 1,0 para os diferentes tamanhos de exemplares e estruturas. Para as dissecções foram utilizados materiais cirúrgicos oftalmológicos, com o espécime imerso em uma cuba com álcool $70 \%$ e fixado por alfinetes entomológicos. Cada exemplar foi dissecado a partir de um corte longitudinal dorsal no meio do corpo e circundando o círculo branquial, que possibilitou expor toda a massa visceral, mostrando de modo geral a anatomia interna, e como estão dispostos os principais sistemas: circulatório, excretor, digestivo, reprodutor e nervoso, descritos nessa sequência para cada espécie. Cada sistema foi isolado para uma análise individual.

As rádulas foram examinadas no Laboratório de Microscopia Eletrônica de Varredura do MZSP e do Instituto de Biociências da USP. A preparação das rádulas se deu através da retirada dessas do odontóforo, em seguida cada rádula foi colocada em uma solução composta de $3 / 4$ de água filtrada e $1 / 4$ de Hipoclorito de Sódio, com a finalidade de retirar qualquer resíduo tecidual dos dentes radulares. A rádula permaneceu nessa solução por um período variável de 03 a 10 minutos, lembrando que foi necessário acompanhar o processo, verificando se a rádula já estava limpa antes dos 10 minutos, pois é uma solução que pode corroer os dentes radulares se ficar mais tempo do que o necessário. Em seguida, a rádula foi colocada em uma solução de 1/2 de água filtrada e $1 / 2$ de limpador de uso geral, como Veja Multiuso, e levada para o ultrassom por 03 minutos. Para finalizar, foi realizado o enxágue da rádula com água filtrada, até não sobrar mais o limpador multiuso. Após conferir se a rádula já estava 
limpa e sem resíduos, esta foi fixada em um stub, com fita dupla face, e encaminhada para metalização e à microscopia de varredura.

A terminologia das estruturas foi baseada em algumas revisões, como Hancock \& Embleton (1852), Hancock (1864), Marcus (1955), Garciá \& Garcia-Gómez (1990), Valdés (2002), Simone (2004).

Os desenhos dos espécimes dissecados foram realizados com a ajuda de uma câmara clara acoplada à lupa estereoscópica, posteriormente foram passados a limpo em papel vegetal com caneta nanquim e digitalizados.

Abreviatura das instituições: MNHN: Muséum National d'Histoire Naturelle, Paris; ZMUC: Zoologisk Museum, Københavns Universitet, Copenhagen; FMNH: Florida Museum of Natural History; MNRJ: Museu Nacional do Rio de Janeiro; MZSP: Museu de Zoologia da Universidade de São Paulo. 


\title{
3. RESULTADOS
}

\section{Ordem NUDIBRANCHIA}

\section{Superfamília DORIDOIDEA}

\author{
Família DORIDIDAE
}

Gênero Doris Linnaeus, 1758

Espécie-tipo: Doris verrucosa Linnaeus, 1758, por monotipia.

Lista sinonímica, ver Valdés (2002: 540-541).

\section{DIAGNOSE:}

Manto amplo, coberto com grandes e numerosos tubérculos arredondados, às vezes pedunculados; em outros casos os tubérculos são interligados internamente por junção de nervuras, reforçados por espículas tegumentares que não sobressaem na superfície dorsal. Tubérculos menores também estão presentes, protegendo a cavidade branquial e rinoforal. Brânquias simples, pinadas, bipinadas ou tripinadas. Cabeça com dois prolongamentos laterais. Borda anterior do pé sulcada, mas não fendida (como em Discocorididae). Cutícula labial sem pregas. Rádula ampla, sem o dente mediano (raquidiano) composta de dentes simples, dentes ultraperiféricos (externos) podem ser simples ou cuspidados. Sistema reprodutor com uma próstata tubular, granular e simples. Pênis e vagina desprovidos de ganchos. Glândula vestibular ou acessória ausente (Thompson, 1975; Valdés, 2002). 


\section{Doris verrucosa Linnaeus, 1758}

(Figs. 1-31)

Doris verrucosa Linnaeus, 1758: 653; 1767: 1083; Pennant, 1777: 36; Cuvier, 1804: 467 (pl. 1, figs. 4-6); Rapp, 1827: 517; Delle Chiaje, 1828: 129, 133 (pl. 38, figs. 14, 23); Philippi, 1836: 104; d'Orbigny, 1839: 39; Fischer, 1867: 7-8; Bergh, 1878: 597; Ihering, 1886: 230; Eliot, 1910: 94; Pruvout-Fol, 1934: 236-239; Marcus, 1955: $127-$ 131(figs. 102-108); 1957: 420 (fig. 90); Marcus \& Marcus, 1967c: 201-203 (fig. 1); Schmekel, 1968a: 169 (fig. 3); Franz, 1970: 80-85; Marcus, 1972: 312-313; Marcus, 1977: 10; Rios, 1985: 184 (pl. 64, fig. 925); 1994: 212 (pl. 72, fig. 1036); 2009: 426; Bouchet \& Valdés, 2000: 74-80; Valdés, 2002: 543-546 (figs. 2-3); Valdés, et. al. 2006: 168-169; García, et. al. 2008: 131-132; Agudo-Padrón, et. al. 2009: 10; Amaral, et. al. 2010: 235.

Doris derelicta Fischer, 1867: 7-8; Bouchet \& Valdés, 2000: 75 (in syn); Valdés, 2002: 546 (in syn).

Doris biscayensis Fischer, 1872: 6-8; Valdés, 2002: 546 (in syn).

Staurodoris verrucosa var. mollis Eliot, 1906a: 338-339; Valdés, 2002: 546 (in syn).

Staurodoris bobretzkii Gadzikiewicz, 1907: 509-510 Valdés, 2002: 546 (in syn).

Material tipo: neótipo depositado MNHN (Paris), análise feita por imagens cedidas pelo Museu de Paris.

Localidade-tipo: Castropol, Asturias, Costa Atlântica da Espanha (Bouchet \& Valdés, 2000). 
Material examinado: ESPANHA, Andaluzia Ocidental, Sancti Petri, MZSP 99538, 2

ex. (L. Cervera col., 29/vi/2010); ITÁLIA, Nápoles, Golfo de Nápoles, MNRJ 2416, 3

ex.

\section{Redescrição}

Morfologia externa (Figs. 1-7): Tamanho variando de 9-15-20 mm. Coloração uniforme entre o amarelado e cinza. Corpo oval, alongado, com noto coberto por tubérculos de quantidade e tamanho variado, os maiores são mias alongados do que arredondados, localizados na região mediana dorsal do noto e diminuem de tamanho à medida que se aproximam da borda do noto. Rinóforos com 13 lamelas, da mesma cor do corpo, borda da cavidade rinoforal possui uma pequena papila nas bordas anterior e posterior e dois tubérculos alongados nos lados direito e esquerdo. Brânquias unipinadas, com 14/15 filamentos retráteis, dispostos de forma circular. Borda da cavidade branquial possui oito tubérculos alongados, equidistantes entre si, de coloração igual ao corpo. Boca abre-se na região anterior ventral, entre a parte anterior do noto e o pé. Prolongamentos laterais do tegumento (tentáculos) com formato triangular e sulco ventral que segue até metade de cada prolongamento, cerca de $1 / 2$ do tamanho da boca, cada. Borda anterior do pé sulcada. Ânus localizado na região central das brânquias, formando uma papila.

Hemocela (Figs. 8-9): A topografia geral do animal, quando aberto por um corte longitudinal dorsal apresenta sobre a massa visceral uma fina membrana (resquício do manto), encobrindo a superfície interna do noto, o pericárdio, e a metade posterior da massa visceral. Aparato bucal anterior. Sistema nervoso dorsal ao aparato bucal e coberto pela glândula de sangue. Sistema reprodutor do lado direito. Estômago do lado esquerdo e intestino seguindo do lado esquerdo para o direito, passando ventral ao 
pericárdio e dorsal à glândula digestiva. Círculo branquial na região mais posterior e dorsal do noto.

Sistema circulatório e excretor (Figs. 16-20): cavidade pericárdica localizada dorsal e posteriormente à glândula digestiva, ocupando aproximadamente $1 / 2$ da massa visceral, anterior ao círculo branquial. Círculo branquial dividido em dois anéis branquiais, o aferente e o eferente, que se ramificam em cada filamento branquial, em veias branquiais aferentes e eferentes. Músculo retrator da brânquia com origem na base do círculo branquial segue longitudinal até aproximadamente a metade do pé e insere na parte dorsal do pé. Aurícula com formado de "funil" com a parte conectada ao círculo branquial duas vezes mais larga do que a porção conectada ao ventrículo e finas paredes. Ventrículo muscular, de formato losangular, apresenta a válvula auriculoventricular, que tem duas abas salientes projetadas para dentro da cavidade do ventrículo, a partir da aurícula. Três vasos principais anteriores: troco aórtico, localizado anteriormente ao pericárdio, conectado à região anterior do ventrículo; vasos auriculares conectando as cavidades laterais do tegumento com a aurícula; e vaso branquicardíaco localizado na extremidade posterior do pericárdio, conectando o anel branquial eferente com a aurícula. Tronco aórtico ramificado em artéria anterior, irrigando estômago, pâncreas e glândula digestiva, e artéria posterior, irrigando sistema reprodutor, massa bucal, odontóforo e sistema nervoso. Seio medial está conectado com o anel branquial aferente e segue anteriormente irrigando toda a glândula digestiva. Vesícula renal localizada no lado direito dorsal dentro do pericárdio, próximo à base da aurícula, conectada com a superfície interna do pericárdio e com a câmara renal, tem formato elíptico, coloração amarelo claro, com pregas longitudinais, cerca de 1/4 do tamanho do ventrículo. Câmara renal se estende anteriormente e dorsal ao seio medial, tendo o 
pericárdio dorsal, e um ramo posterior que segue para o centro do círculo branquial para abrir-se no nefróstoma, situado na base da papila anal.

Sistema digestivo (Figs. 16; 23-30): aparato bucal ocupando cerca de $10 \%$ da massa visceral. Tubo oral composto pelo lábio externo, todo pregueado longitudinalmente, e o lábio interno com uma prega transversal. Odontóforo oval, conectado com o tubo oral por vários músculos $(\mathbf{m 1 0})$ finos, protratores longitudinais dorsais e ventrolaterais com origem na região anterior do odontóforo e inserção na região posterior do tegumento do tubo oral, passando dorsal e ventral ao esfíncter bucal. Esfíncter bucal robusto circunda uma parte quitinosa que segue ao tubo oral e se conecta com a parte glandular do esôfago que fica sobre a rádula. Músculos: m1) três pares de músculos retratores da massa bucal, com origem no tubo oral e inserção nas laterais do corpo, passam dorsal e ventralmente ao tubo oral e com aproximadamente seis vezes a largura e duas vezes o comprimento do $\mathrm{m} 10 ; \mathbf{m} 2)$ par de músculos retratores fortes, que ocupa cerca de 2/9 do odontóforo, tão largo quanto longos, com formato triangular, origem na região anterior dorsal do odontóforo, passando lateral ao m4 e inseridos ventralmente na parte dorsal do pé; m4) par de fortes e largos músculos tensores dorsais, ocupa 4/9 do odontóforo, 1/3 mais longo do que largo, com formato retangular, originados na lateral da cartilagem do odontóforo, cobrindo $2 / 3$ da cartilagem, inseridos na parte ventral da membrana subradular; m5) par de músculos tensores dorsais auxiliares, ocupa 2/9 do odontóforo, duas vezes mais longo do que largo, origina-se na região mais posterior da cartilagem do odontóforo cobre o $1 / 3$ posterior da cavidade do odontóforo, tem aproximadamente o mesmo tamanho e $1 \frac{1}{2}$ da largura do $\mathrm{m} 4$ e insere-se na parte ventral da membrana subradular circundando o saco radular; m6) músculo horizontal ímpar, com fibras transversais, ocupa 1/9 do comprimento do odontóforo, tem aproximadamente o mesmo tamanho e $1 / 2$ da largura do $m 4$, conecta-se à superfície 
mediana das duas cartilagens do odontóforo, parte posterior aproximadamente duas vezes mais larga do que a anterior, em formato de "funil". O par de cartilagens do odontóforo com formato elíptico ocupa aproximadamente $2 / 9$ do odontóforo. Membrana subradular fina, forte e semitransparente. Saco radular cerca de 1/3 do tamanho total do odontóforo. Dentes radulares (Figs. 5-8): dente raquidiano ausente, com fórmula radular apresentando 32 fileiras com 40.0.40 dentes, em um exemplar com $9 \mathrm{~mm}$ de comprimento. Cada dente lateral apresenta uma base larga e se afunila na ponta com formato de gancho, com uma cúspide terminal simples e sem cúspides secundárias, os dentes mais externos são mais delgados, cerca de metade da base dos dentes mais interno, também com a ponta em formato de gancho, cúspide simples e lisa. Esôfago com pregas longitudinais internas, conectado dorsalmente ao odontóforo, tem o mesmo diâmetro em toda sua extensão, conecta-se diretamente com a região anterior do estômago. Par de glândulas salivares tubulares e longas, inseridas na a região anterior do esôfago por um ducto, afunilamento da glândula, estendem-se até a região anterior da glândula digestiva. Estômago oval, ocupando aproximadamente $30 \%$ da massa visceral, superfície interna toda pregueada, com pregas concentradas no centro do estômago e pregas longitudinais e mais grossas que as centrais na porção posterior que se afunila e segue para o intestino, com uma abertura para o ducto da glândula digestiva e uma abertura comum no ponto em que se conecta com o esôfago e com o pâncreas. Intestino com pregas longitudinais em toda sua extensão, inserido com a parte posterior do estômago, diâmetro aproximadamente $1 / 2$ do que o do esôfago, porém mais uniforme. Ceco (também chamado de divertículo) localizado ventralmente ao estômago, com abertura na porção anterior do estômago e próximo à inserção do esôfago, saco alongado, cerca de 1/2 do tamanho e 1/3 da largura do estômago, normalmente contém uma substância de coloração marrom escura. Glândula digestiva com coloração bege 
escuro, maior órgão da massa visceral, ocupando cerca de $40 \%$ da massa visceral, com formato cônico com a porção anterior duas vezes mais larga do que a posterior, aspecto esponjoso da face interna, vários ductos, mas um ducto principal. Ânus projeta-se através da papila anal, que é aproximadamente 1/6 do tamanho dos filamentos branquiais, no centro do círculo branquial.

Sistema reprodutor (Figs. 31-33): ocupa aproximadamente 10\% da massa visceral entre a massa bucal e a glândula digestiva, localizado do lado direito, visto dorsalmente, com abertura genital no mesmo lado, no $1 / 3$ anterior, próximo à cabeça, entre o noto e o pé. Ducto hermafrodito fino e longo, conectado com a gônada, essa abrigada na glândula digestiva. Ampola situada sobre a glândula feminina, estrutura alongada e tubular. Próstata tubular, glandular, com aspecto enevoado, com aproximadamente o mesmo comprimento da ampola. Ducto deferente com aproximadamente o mesmo comprimento do pênis, se insere próximo a origem do músculo do pênis. Músculo do pênis conectado com a porção ventral do pericárdio, próximo do ventrículo, aproximadamente o mesmo comprimento que o pênis. Pênis cilíndrico, alongado, muscular, cerca de $2 / 3$ do tamanho da próstata. Gônada imersa na glândula digestiva. Glândula feminina bem desenvolvida, arredondada, irregular, ocupa $15 \%$ do sistema reprodutor, está dividida em glândula mucosa que ocupa $2 / 3$ e apresenta uma coloração bege, e glândula de albume ocupando $1 / 3$ da região mais anterior, dilatado com formato irregular e com uma coloração marrom escuro. Oviduto ocupando cerca de $1 / 3$ do tamanho da glândula feminina. Ducto uterino fino e relativamente curto, aproximadamente $1 / 30$ do comprimento do pênis, na base da vagina, insere na glândula feminina próximo do oviduto. Receptáculo seminal piriforme, com o mesmo tamanho da bursa copulatrix e aproximadamente $1 / 3$ do comprimento da vagina, conectado com a vagina, próximo ao ducto uterino, através de 
uma curta haste. Bursa copulatrix com formato arredondado, aproximadamente $1 / 3$ do comprimento da vagina, se conecta com a vagina após o receptáculo seminal, também através de uma curta haste. Vagina cilíndrica, alongada, com aproximadamente o mesmo comprimento e duas vezes a largura do pênis, passando ventral à próstata e segue paralela ao pênis até a abertura genital.

Sistema nervoso (Figs. 34-36): ocupa toda a vista dorsal do odontóforo, cerca de 1/20 da hemocela e está coberto pela glândula de sangue. Com o par de gânglios cerebrais, pleurais fundidos dorsalmente e ventral a eles está o par de gânglios pediosos, que não estão fundidos entre si, mas com os cerebrais e pleurais, um de cada lado. Par de gânglios cerebrais e pleurais parcialmente fundidos, distintos do par de gânglios pediosos. Gânglios pediosos conectados através da comissura pediosa simples, que circunda esôfago e glândulas salivares e tem aproximadamente duas vezes o tamanho dos gânglios cerebrais, pediosos e pleurais juntos. Gânglios bucais conectados por uma curta comissura, localizados na porção ventral do odontóforo, entre o saco radular e a parte anterior do esôfago, estão ligados aos gânglios cerebrais através de um longo e delgado conectivo, e aos gânglios gastro-esofágicos por um conectivo curto. Gastroesofágicos com cerca de $1 / 3$ do tamanho do gânglio bucal, com formato circular. Gânglios rinoforais (olfatórios) com formato de bulbo, conectados com a porção anterior dos gânglios cerebrais. Olhos dorsais, situados nos gânglios cerebrais. Estatocistos localizados interiormente aos gânglios pediosos, pequenos e iridescentes.

Distribuição: Costa Atlântica da Europa e Mar Mediterrâneo. Regiões confirmadas: Espanha e Nápoles, Itália.

Habitat: área de costão rochoso da região infralitoral. 


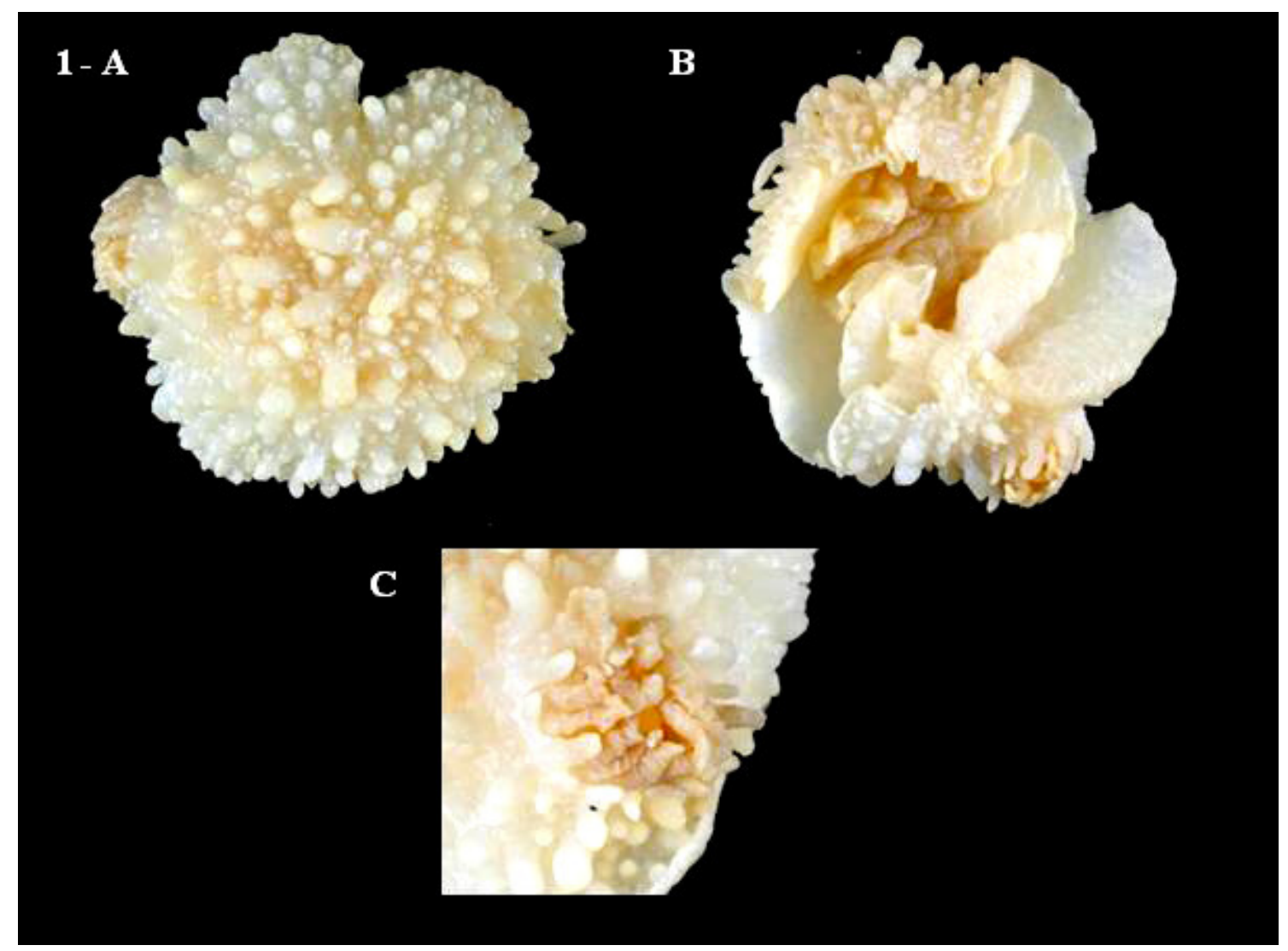

Figuras 1 (A-C): Neótipo de Doris verrucosa (MNHN 24625), animal fixado. 1-A. Vista dorsal. B. Vista ventral. C. Região posterior, detalhe do círculo branquial, vista dorsal. Sem escalas. Fotos cedidas pelo Museu Nacional de História Natural de Paris. 


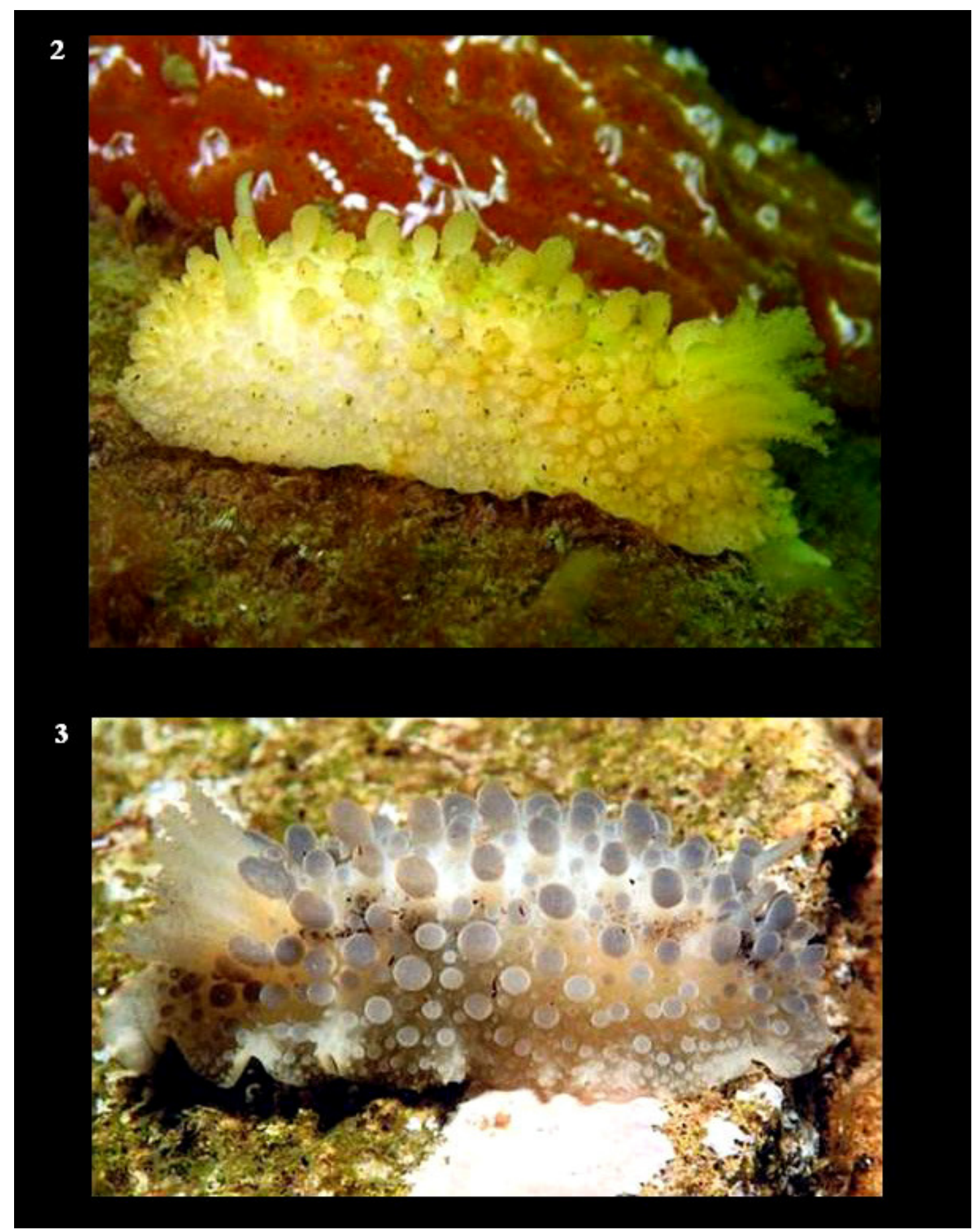

Figuras 2-3. Doris verrucosa in vivo, exemplares do Mediterrâneo. 2. Vista lateral esquerda. Extraído de Bielecki (2002). 3. Vista lateral direita. Extraído de Rudman (2009) 


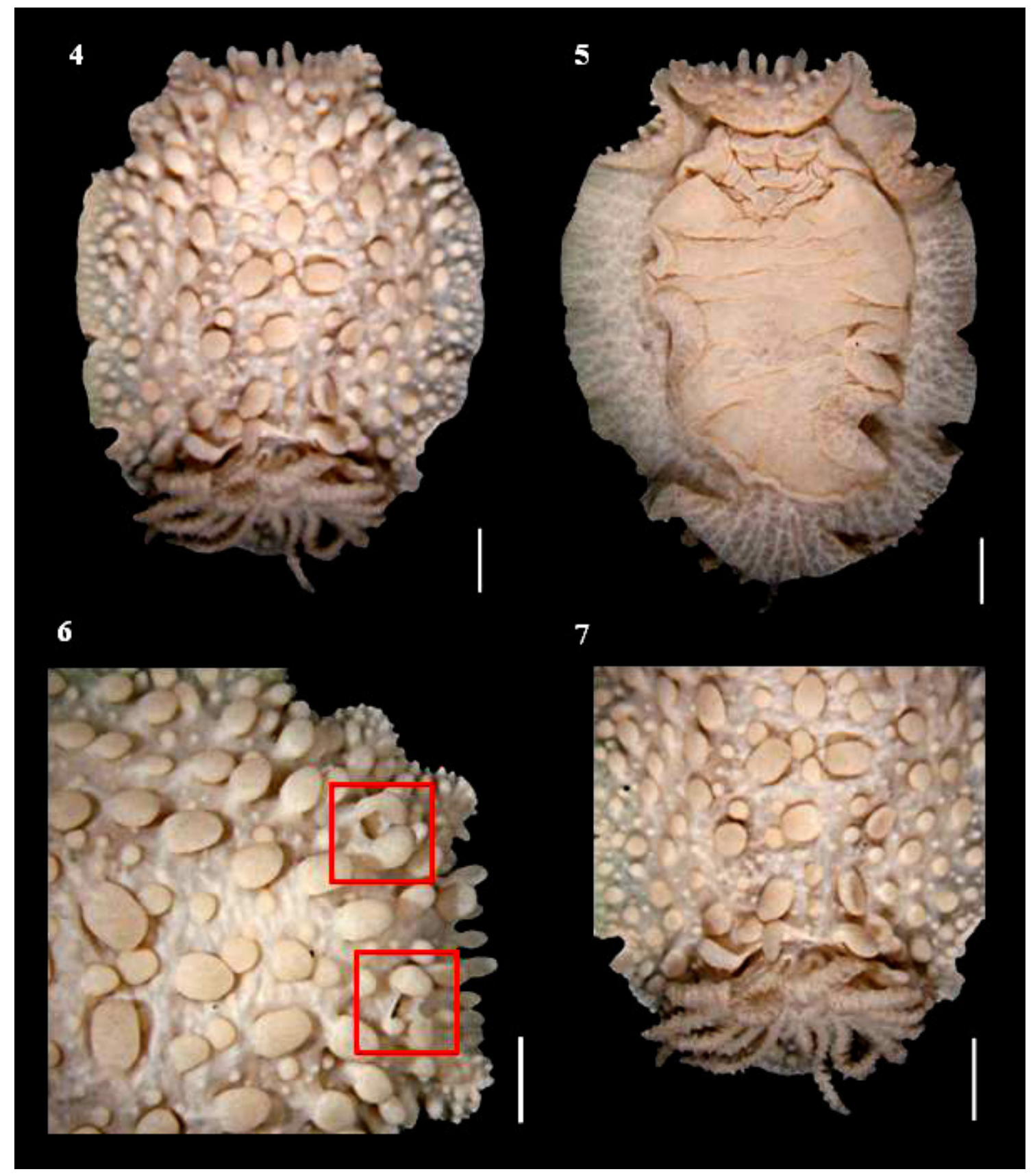

Figuras 4-7: Doris verrucosa (MNRJ 2416), animal fixado. 4. Vista dorsal. 5. Vista ventral. 6. Região anterior com destaque para os tubérculos alongados ao redor da cavidade rinoforal, vista dorsal. 7. Região posterior, detalhe do círculo branquial, vista dorsal. Escalas: $2 \mathrm{~mm}$. 

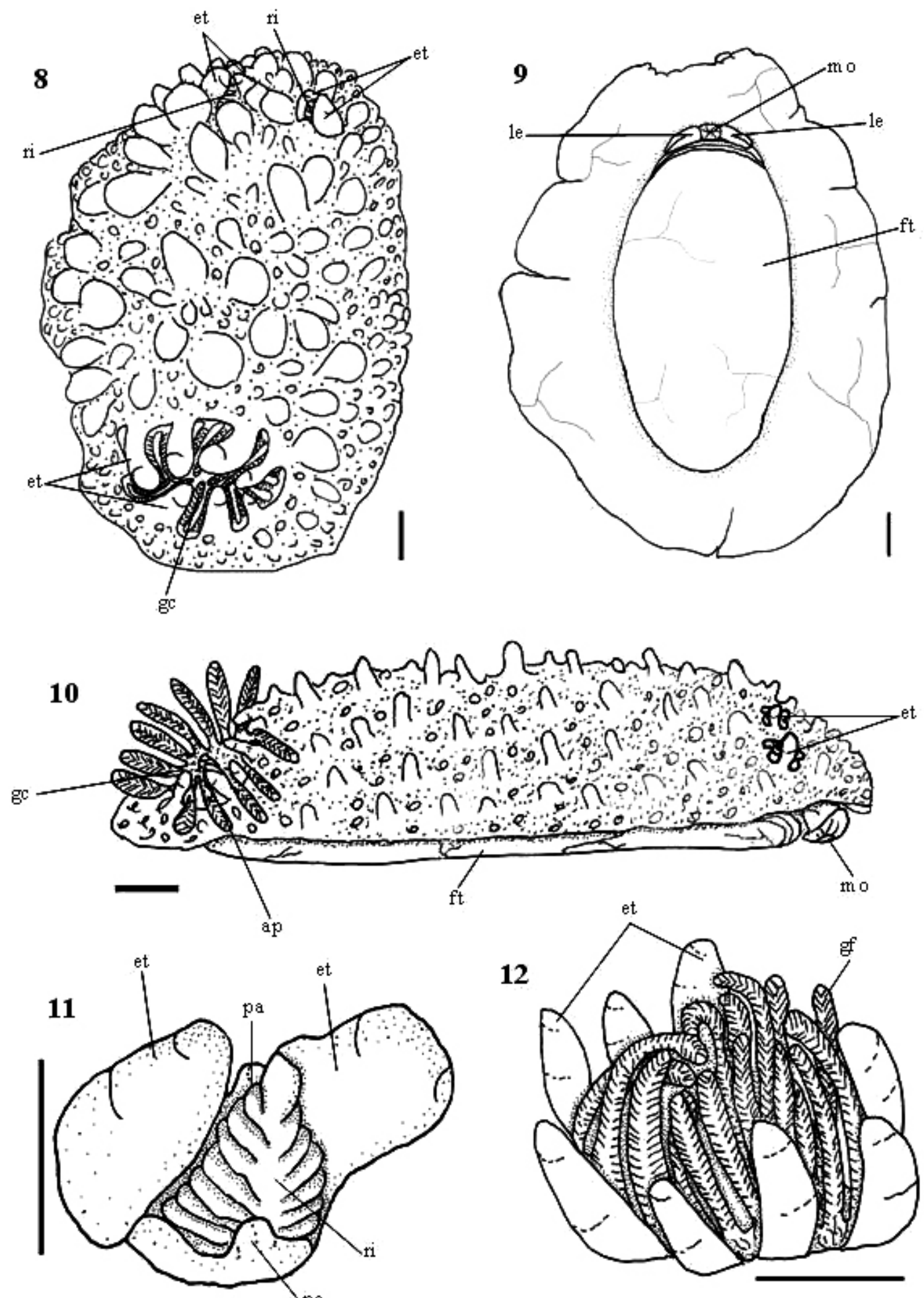

Figuras 8-10. Morfologia externa de Doris verrucosa. 8. Vista dorsal. 9. Vista ventral. 10. Vista lateral direita. Escalas: $1 \mathrm{~mm}$. 11. Detalhe da cavidade do rinóforo, vista dorsal. 12. Círculo branquial, vista dorsal. Escalas: 0,5 mm. Abreviaturas - ap: papila anal; et: tubérculo alongado; ft: pé; gc: círculo branquial; gf: filamento branquial; le: prolongamento lateral; mo: boca; pa: papila; ri: rinóforo. 

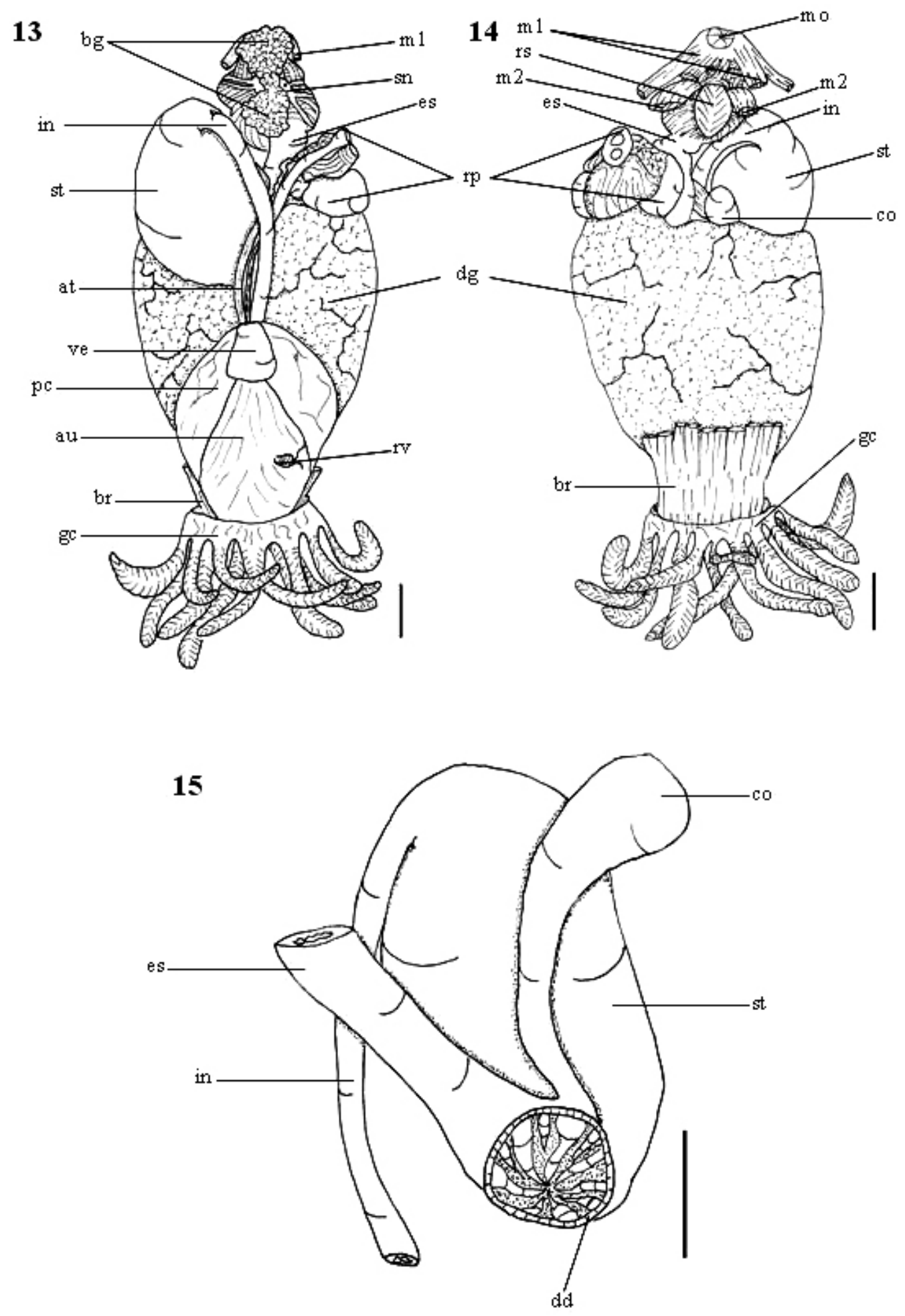

Figuras 13-44. Estrutura da hemocela de Doris verrucosa. 13. Vista dorsal. 14. Vista ventral. 15. Sistema digestivo médio, vista ventral, com abertura para a glândula digestiva. Escalas: $1 \mathrm{~mm}$. Abreviaturas: at: tronco aórtico; bg: glândula de sangue; br: músculo retrator da brânquia; co: ceco; dd: ducto da glândula digestiva; dg: glândula digestiva; es: esôfago; gc: círculo branquial; in: intestino; m1: músculos retratores da massa bucal; m2: músculo do odontóforo; pc: pericárdio; rp: sistema reprodutor; rs: saco radular; rv: vesícula renal; st: estômago; ve: ventrículo. 
16

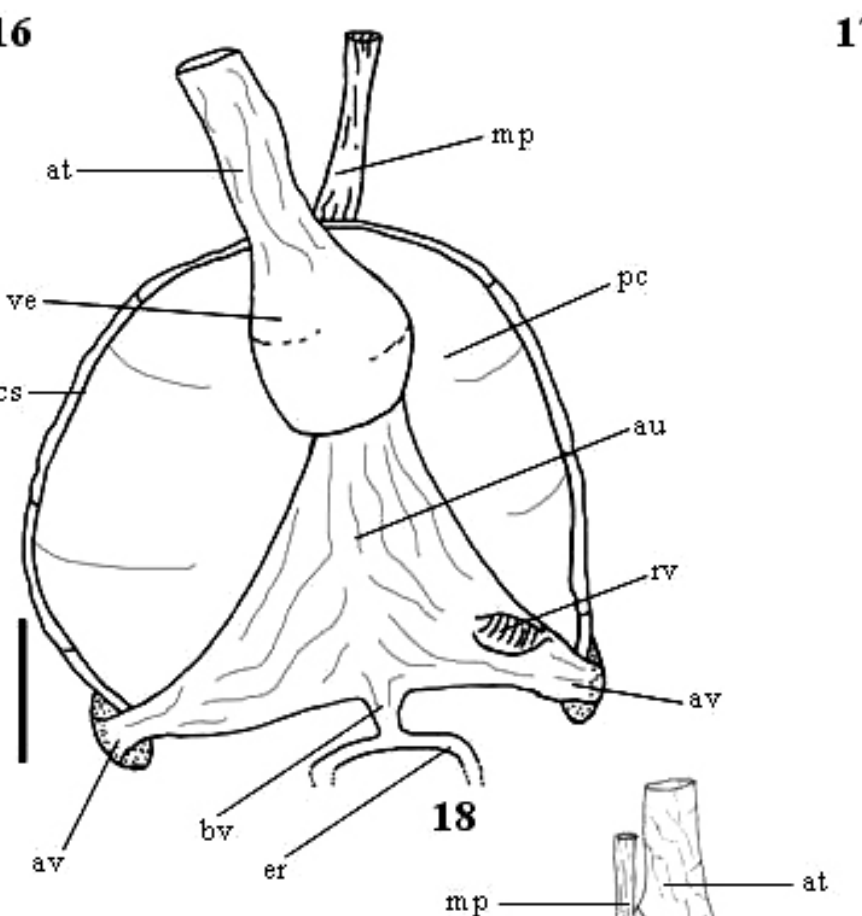

17

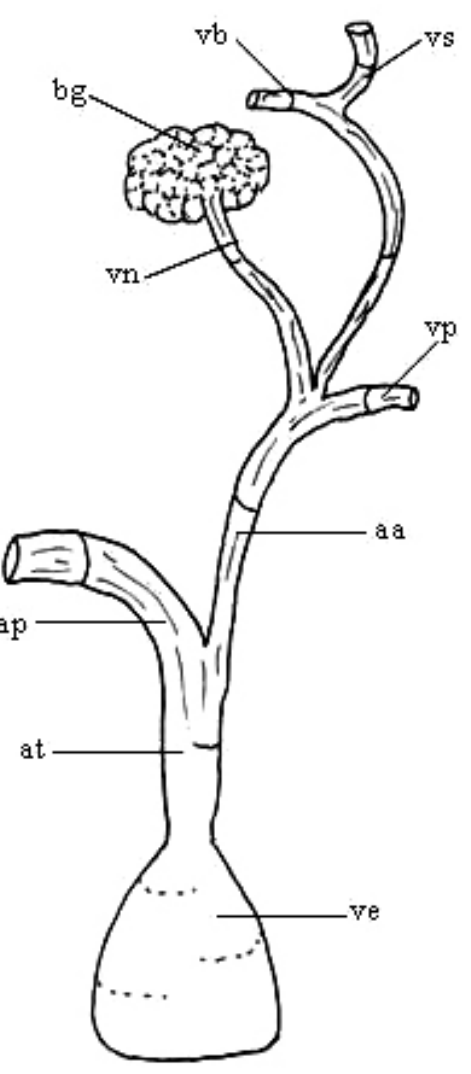

19
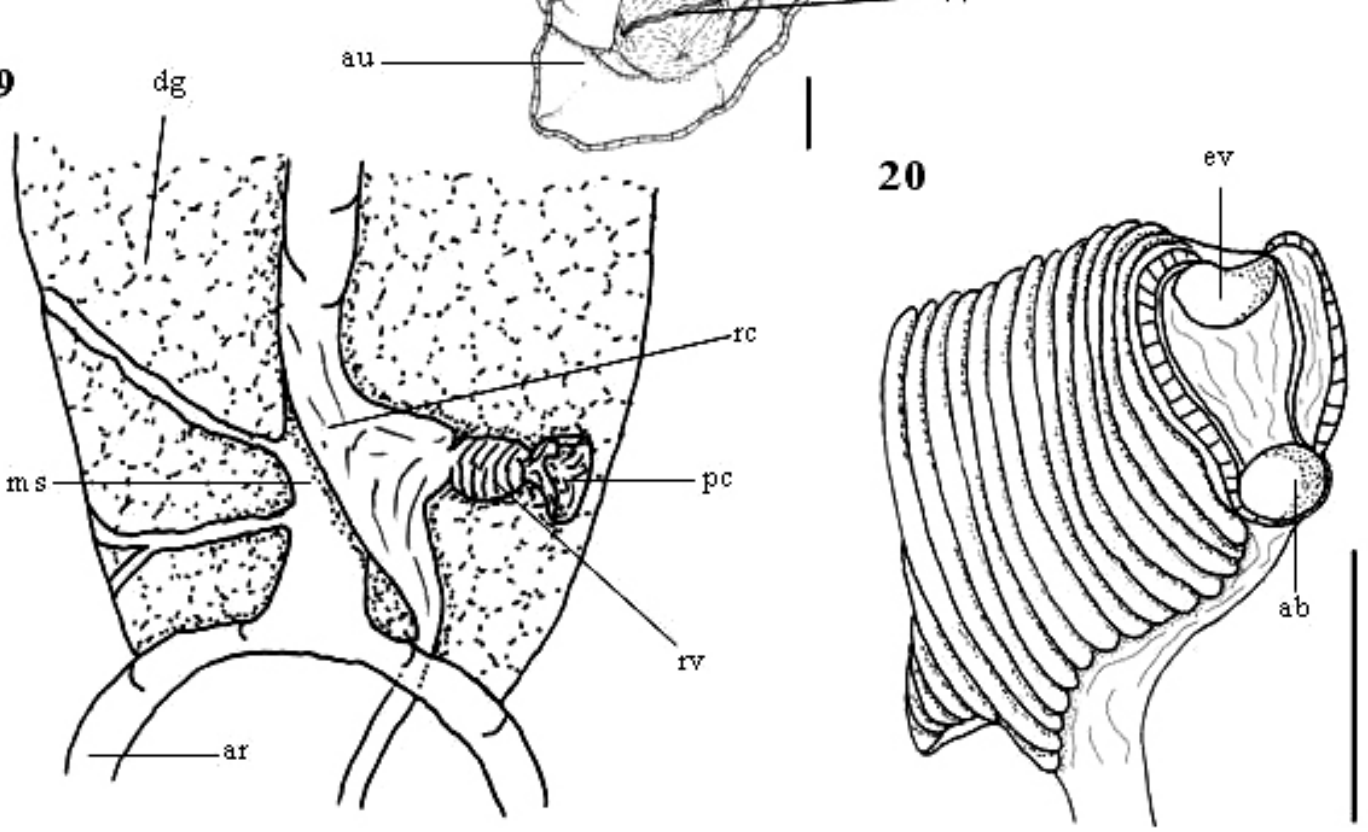

Figuras 16-20. Sistema circulatório e excretor de Doris verrucosa. 16. Órgãos envolvidos pelo pericárdio, vista dorsal. 17. Esquema dos vasos da circulação arterial, vista dorsal, 18. Detalhe da válvula auriculoventricular, vista dorsal posterior. 19. Esquema em vista dorsal dos órgãos do sistema excretor, baseado em Garciá \& Garciá-Gómez, 1990. 20. Filamento branquial em vista lateral com corte apical com destaque para os vasos aferente e eferente. Escalas: $1 \mathrm{~mm}$, Abreviaturas: aa: aorta anterior; ab: veia branquial aferente; ap: aorta posterior; ar: anel branquial aferente; au: aurícula; at: tronco aórtico; av: veia auricular; bm: massa bucal; bv: veia branquiocardíaca; cs: seio circular; dg: glândula digestiva; er: anel branquial eferente; ev: veia branquial eferente; ms: seio medial; pc: pericárdio; rc: câmara renal; vb: veia da massa bucal; vp: veia do sistema reprodutor; vn: veia do sistema nervoso: vs: veia do saco radular; rv: vesícula renal; ve: ventrículo; vv: válvula auricoventricular. 

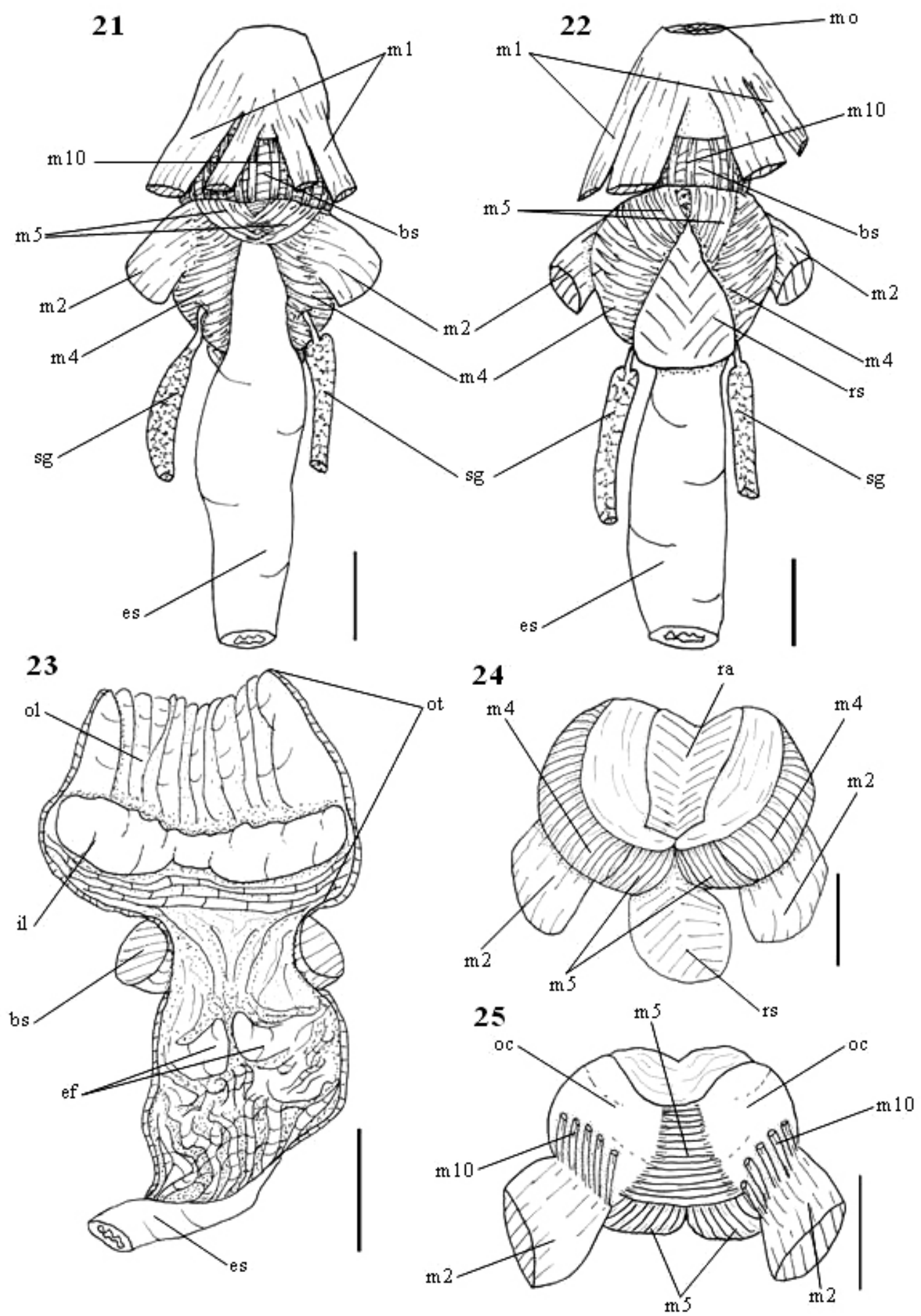

Figuras 21-23. Sistema digestivo anterior de Doris verrucosa. 21. Vista dorsal. 22. Vista ventral. 23. Corte longitudinal, vista ventral e odontóforo removido. 24-25. Odontóforo. 24. Vista ventral. 25. Vista dorsal. Escalas: $1 \mathrm{~mm}$. Abreviaturas: bs: esfíncter bucal; ef: pregas esofágicas; es: esôfago; il: lábio interno; m1: músculos retratores da massa bucal; m2-m10: músculos do odontóforo; mo: boca; ol: lábio externo; ot: tubo oral; ra: rádula; rs: saco radular; sg: glândula salivar. 

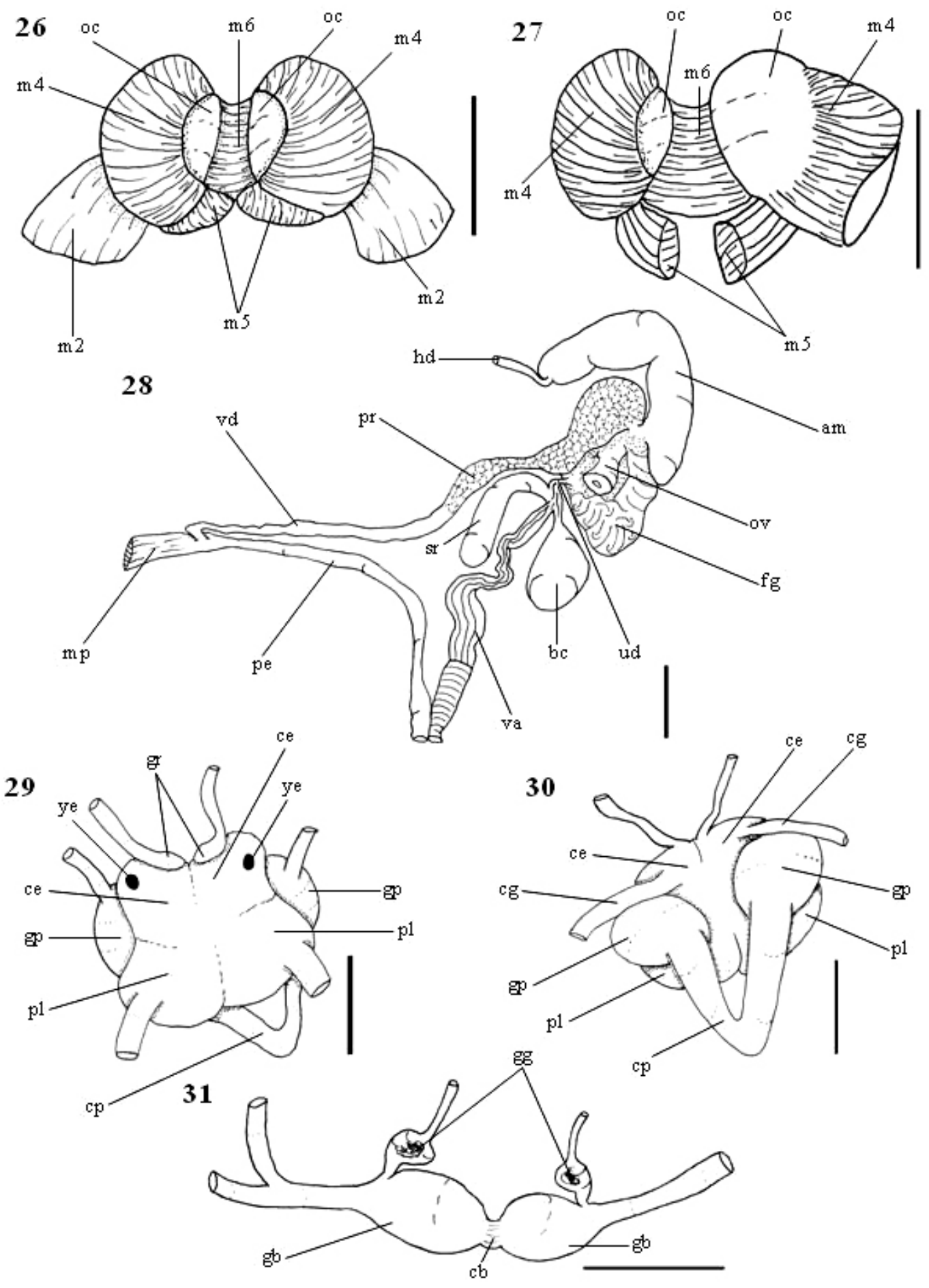

Figuras 26-27. Odontóforo de Doris verrucosa. 26. Vista ventral, rádula removida. 27. Vista ventral, $\mathrm{m} 4$ e $\mathrm{m} 5$ rebatidos com exposição da cartilagem do odontóforo. Escalas: $1 \mathrm{~mm}$. 28. Sistema reprodutor, vista dorsal. 29-31. Sistema nervoso. 29. Vista dorsal. 30. Vista ventral. 31. Detalhe do gânglio bucal e gastroesofágico, vista ventral; Escalas: $1 \mathrm{~mm}$. Abreviaturas - am: ampola; bc: bursa copulatrix; cb: comissura bucal; ce: gânglio cerebral; cg: conectivo do gânglio bucal; cp: comissura pediosa; du: ducto uterino; fg: glândula feminina; gb: gânglio bucal; gg: gânglio gastro-esofágico; gp: gânglio pedioso; gr: gânglio rinoforal; hd: ducto hermafrodita; m2-m10: músculos do odontóforo; pe: pênis; pl: gânglio pleural; pr: próstata; ra: radula; rs: saco radular; sr: receptáculo seminal; va: vagina; ye: olhos. 


\section{Doris januarii (Bergh, 1878) comb. nov.}

(Figs. 32-58)

Staurodoris januarii Bergh, 1878a: 583-585, pl. 63, fig. 24, pl. 64, figs 8-12; Marcus, 1957: 420; Valdés, 2002: 543 (in syn de Doris verrucosa).

Material tipo: De acordo com Valdés (2002), o material tipo de Staurodoris januarii não foi localizado no ZMUC e está provavelmente perdido.

Localidade-tipo: Rio de Janeiro, Brasil.

Material examinado: BRASIL. Pernambuco: Tamandaré, Rio Arinquidá, MNRJ 12932, 2 ex. (L. Manzoni col., 02/xii/2007); Rio de Janeiro: Cabo Frio, Canal do Itajurú, MZSP 96000, 1 ex. (V. Padula col., 18/v/2010), MZSP 96001, 2 ex. (V. Padula col., 18/iv/2010), MZSP 96899, 1 ex. (V. Padula col., 8/xii/2007); Rio de Janeiro, Praia da Urca, MNRJ 10668, 2 ex. (R. Norelli col., 10/v/1985); Angra dos Reis, Ilha do Cavaco, MNRJ 8197, 3 ex. (J.H. Leal col., 1979); São Paulo: São Sebastião, MZSP 13296, 6 ex.; MZSP 31512, 3 ex. (1916), Praia do Varadouro, MZSP 31513, 6 ex. (25/iii/1975), Araçá, MZSP 102797, 1 ex. (P. Oristanio col., 12/xii/2011), Praia do Segredo, MZSP 103203, 1 exemplar (C.M.Cunha col. 17/i/2012); Santos, Ilha de Umbuqueçaba, MZSP 39128, 1 exemplar (C.M.Cunha col. 3/ix/2001); São Vicente, Ilha das Palmas, MZSP 75973, 14 exemplares (Eurico col., 26/vii/1973)

\section{Redescrição}

Morfologia externa (Figs. 32-35; 40-42): Tamanho variando de 10-20-40 mm de comprimento. Coloração uniforme em cada espécime varia entre o amarelado, esverdeado, marrom e cinza. Corpo oval, alongado, com noto coberto por tubérculos 
arredondados variando em quantidade e tamanho variado, os maiores estão localizados na região mediana dorsal do noto e diminuem de tamanho à medida que se aproximam da borda do noto. Rinóforos com 9 lamelas, borda da cavidade rinoforal possui uma pequena papila nas bordas anterior e posterior e dois tubérculos alongados nos lados direito e esquerdo, como em Doris verrucosa. Brânquias unipinadas, com 16 filamentos dispostos de forma circular, borda da cavidade branquial possui oito tubérculos alongados, como em $D$. verrucosa. Boca abre-se na região anterior ventral, entre a parte anterior do noto e o pé. Prolongamentos laterais do tegumento (tentáculos) com formato triangular e sulco ventral que segue até metade de cada prolongamento, cerca de $1 / 2$ do tamanho da boca, cada. Borda anterior do pé sulcada. Ânus localizado na região central das brânquias, formando uma papila.

Hemocela (Figs. 43-44): A topografia geral do animal, quando aberto por um corte longitudinal dorsal apresenta sobre a massa visceral uma fina membrana (resquício do manto), encobrindo a superfície interna do noto, o pericárdio, e a metade posterior da massa visceral. Aparato bucal anterior. Sistema nervoso dorsal ao aparato bucal e coberto pela glândula de sangue. Sistema reprodutor do lado direito. Estômago do lado esquerdo e intestino seguindo do lado esquerdo para o direito, passando ventral ao pericárdio e dorsal à glândula digestiva. Círculo branquial na região mais posterior e dorsal do noto.

Sistema circulatório e excretor (Figs. 43): mantém o mesmo padrão da espécie anterior, com cavidade pericárdica localizada dorsal e posteriormente à glândula digestiva, ocupando aproximadamente $1 / 3$ da hemocela, anterior ao círculo branquial. Músculo retrator da brânquia presente. Aurícula com formado de funil com a parte conectada ao círculo branquial duas vezes mais larga do que a porção conectada ao ventrículo e finas paredes. Ventrículo muscular, de formato piriforme, duas vezes mais 
largo na conexão com a aurícula do que na junção com o tronco aórtico. Ramificação do tronco aórtico segue o padrão de $D$. verrucosa.

Sistema digestivo (Figs. 45; 46-53): aparato bucal ocupando cerca de $10 \%$ da massa visceral. Massa bucal e odontóforo com características similares às descritas para D. verrucosa, com as seguintes diferenças: m2) ocupa cerca de 1/4 da cartilagem do odontóforo, aproximadamente a mesma largura, três vezes mais longo e com metade da espessura do descrito para D. verrucosa, com origem na região anterior do odontóforo, passando lateral ao m4 e inseridos ventralmente na parte dorsal do pé; m4) ocupa 4/9 do odontóforo, duas vezes mais longo do que largo, com formato retangular, originados na lateral da cartilagem do odontóforo, cobrindo $4 / 5$ da cartilagem, inseridos na parte ventral da membrana subradular; m5) ocupa 1/5 da cartilagem do odontóforo, 2/3 mais longo do que largo, origina-se na região mais posterior da cartilagem do odontóforo cobre o 1/5 posterior da cavidade do odontóforo, tem aproximadamente o mesmo tamanho e 1/4 da largura do m4 e insere-se na parte ventral da membrana subradular circundando o saco radular; m6) ocupa $1 / 2$ da cartilagem do odontóforo, tem a parte posterior aproximadamente três vezes mais larga do que a anterior, e cerca de metade da espessura do descrito para $D$. verrucosa; m7) par de músculos finos, que seguem paralelos na porção ventral com origem próximo à parte exposta da rádula e inserção na região mediana posterior do saco radular. O par de cartilagens do odontóforo é grande e com formato elíptico. Membrana subradular fina, forte e semitransparente. Saco radular cerca de $3 / 4$ do tamanho total do odontóforo. Dentes radulares (Figs. 36-39): dente raquidiano ausente, variando entre 32 fileiras com 40.0.40 dentes, em um exemplar com $13 \mathrm{~mm}$ de comprimento e 47 fileiras com 57.0.57 dentes, em um exemplar com $30 \mathrm{~mm}$ de comprimento. Cada dente lateral apresenta uma base larga e se afunila na ponta com formato de gancho, com uma cúspide simples, os dentes mais externos são mais 
delgados, cerca de metade da base, também com a ponta em formato de gancho, cúspide simples e lisa. Estômago oval, ocupando aproximadamente $15 \%$ da massa visceral, superfície interna toda pregueada, com pregas horizontais concentradas no centro do estômago e pregas longitudinais e mais grossas que as centrais na porção posterior que se afunila e segue para o intestino, com uma abertura para o ducto da glândula digestiva e uma abertura comum no ponto em que se conecta com o esôfago e com o ceco. Intestino segue o mesmo padrão descrito anteriormente. Ceco alongado, localizado ventralmente ao estômago, sem conexão com o intestino, cerca de 1/4 do tamanho do estômago. Glândula digestiva com coloração bege escuro, ocupando cerca de $60 \%$ da massa visceral, com formato cônico com a porção anterior três vezes mais larga do que a posterior, aspecto esponjoso da face interna, vários ductos, mas um ducto principal; Ânus segue o mesmo padrão de D. verrucosa, com aproximadamente $2 / 3$ do tamanho dos filamentos branquiais.

Sistema reprodutor (Figs. 54-55): ocupa aproximadamente $15 \%$ da massa visceral. Mantém o mesmo padrão de D. verrucosa. Ampola alongada e tubular, aproximadamente $1 / 3$ mais fina do que em D. verrucosa. Próstata tubular, glandular, com aproximadamente o mesmo comprimento da ampola. Ducto deferente três vezes mais curto do que o descrito para $D$. verrucosa. Músculo do pênis presente. Pênis cilíndrico, alongado, muscular, cerca de $1 \frac{1}{2}$ do tamanho da próstata. Gônada imersa na glândula digestiva. Glândula feminina bem desenvolvida, arredondada, irregular, ocupa $70 \%$ do sistema reprodutor, está dividida em glândula mucosa que ocupa 4/5 e apresenta uma coloração bege, e glândula de albume ocupando 1/5 da região mais anterior, dilatado com formato irregular e com uma coloração marrom escuro. Oviduto ocupando cerca de 1/5 do tamanho da glândula feminina. Ducto uterino 1/3 mais longo do quem em $D$. verrucosa. Receptáculo seminal piriforme, com 1/5 do tamanho da 
bursa copulatrix, conectado com a vagina, próximo ao ducto uterino, através de uma curta haste. Bursa copulatrix com formato arredondado, se conecta com a vagina após o receptáculo seminal, também através de uma curta haste. Vagina cilíndrica, alongada, 1/3 mais comprida e com a mesma largura do pênis, passando ventral à próstata e segue paralela ao pênis até a abertura genital.

Sistema nervoso (Figs. 43; 56-58): dorsal ao odontóforo e coberto pela glândula de sangue, ocupa cerca de 1/20 da hemocela. Par de gânglios cerebrais e pleurais parcialmente fundidos, distintos do par de gânglios pediosos. Gânglios pediosos conectados através da comissura pediosa dupla, que circunda esôfago e glândulas salivares e tem aproximadamente duas vezes o tamanho dos gânglios cerebrais, pediosos e pleurais juntos. Gânglios bucais conectados por uma curta comissura, localizados na porção ventral do odontóforo, entre o saco radular e a parte anterior do esôfago, estão ligados aos gânglios cerebrais através de um longo e delgado conectivo, e aos gânglios gastro-esofágicos por um conectivo curto. Gastro-esofágicos com cerca de 1/5 do tamanho do gânglio bucal, com formato circular. Gânglios rinoforais (olfatórios) com formato de bulbo, conectados com a porção anterior dos gânglios cerebrais. Olhos dorsais, situados nos gânglios cerebrais, mais próximos um do outro do que em $D$. verrucosa. Estatocistos localizados interiormente aos gânglios pediosos, pequenos e iridescentes.

Distribuição: de Pernambuco a Santa Catarina. Regiões confirmadas: Pernambuco, Rio de Janeiro, São Paulo, Santa Catarina.

Habitat: área de costão rochoso da região infralitoral, na época reprodutiva pode ser encontrada próxima a áreas cobertas pela esponja incrustante Hymeniacidon heliophila Parker, 1910, até 12 m de profundidade (Martins, et. al., 2010). 


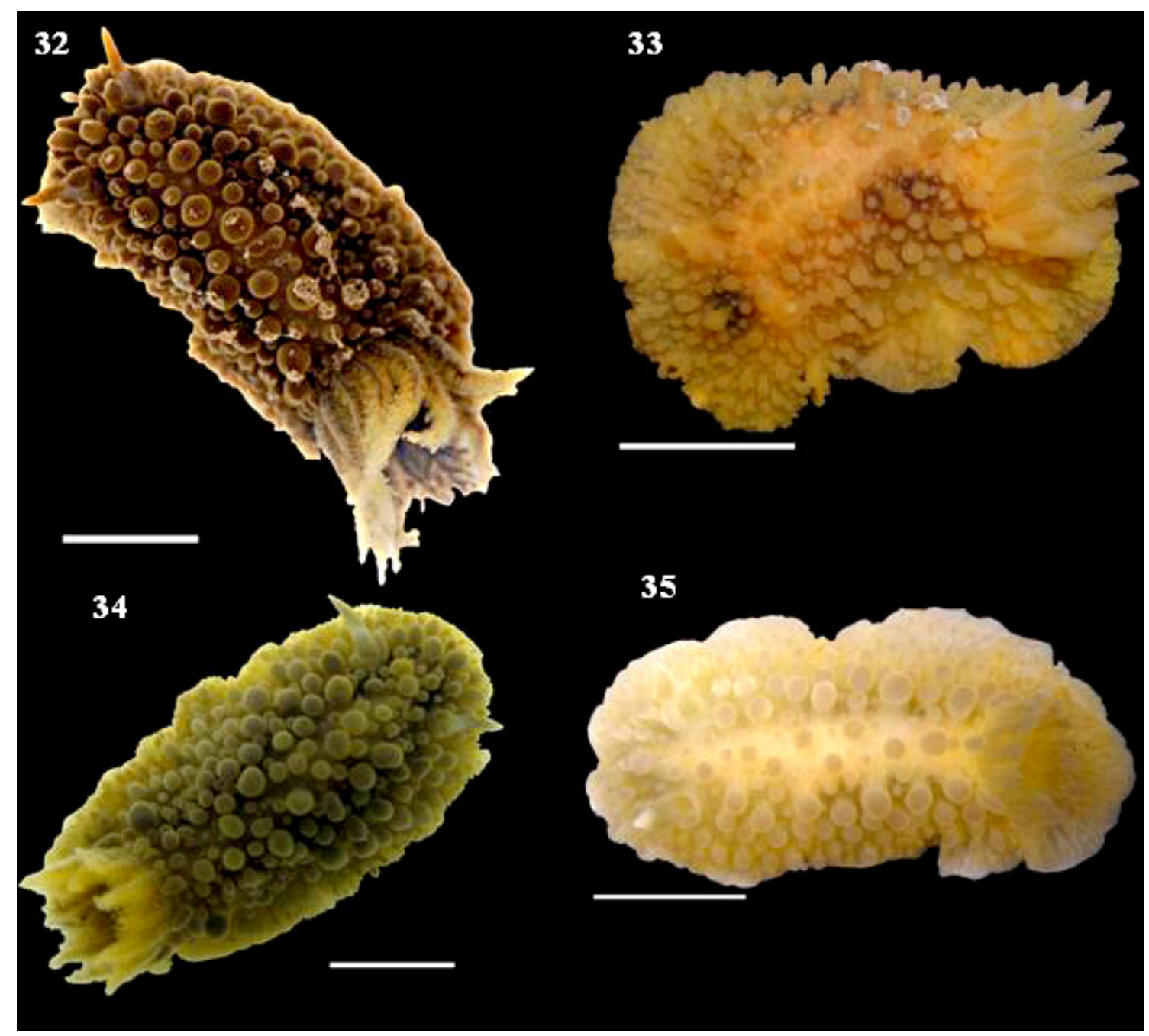

Figuras 32-35. Variação de coloração de Doris januarii. 32. Rio Arinquidá, Tamandaré/PE (MNRJ 12932). 33. Praia das Conchas, Cabo Frio/RJ (MZSP 96899). 34. Canal de Itajurú, Cabo Frio/RJ (MZSP 96900). 35. Araçá, São Sebastião/SP (MZSP 102797). Escalas: 2 mm. 

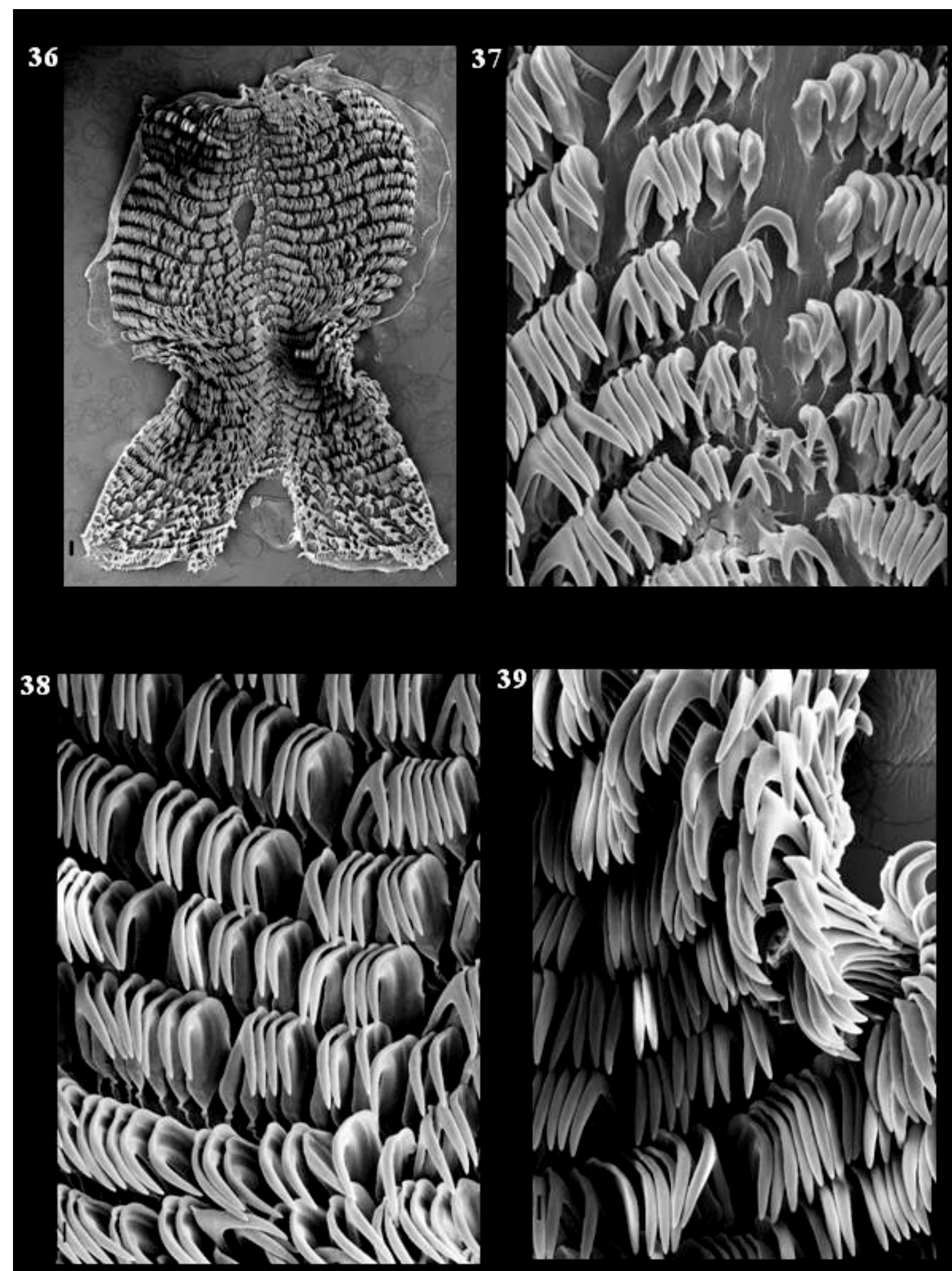

Figuras 36-39. Microscopia eletrônica da rádula de Doris januarii. (MZSP 31513). 36. Vista panorâmica geral. Escala: $100 \mu \mathrm{m}$. 37. Vista central dos dentes laterais mais internos. 38. Vista interna dos dentes laterais. 39. Dentes laterais mais externos. Escalas: $20 \mu \mathrm{m}$. 

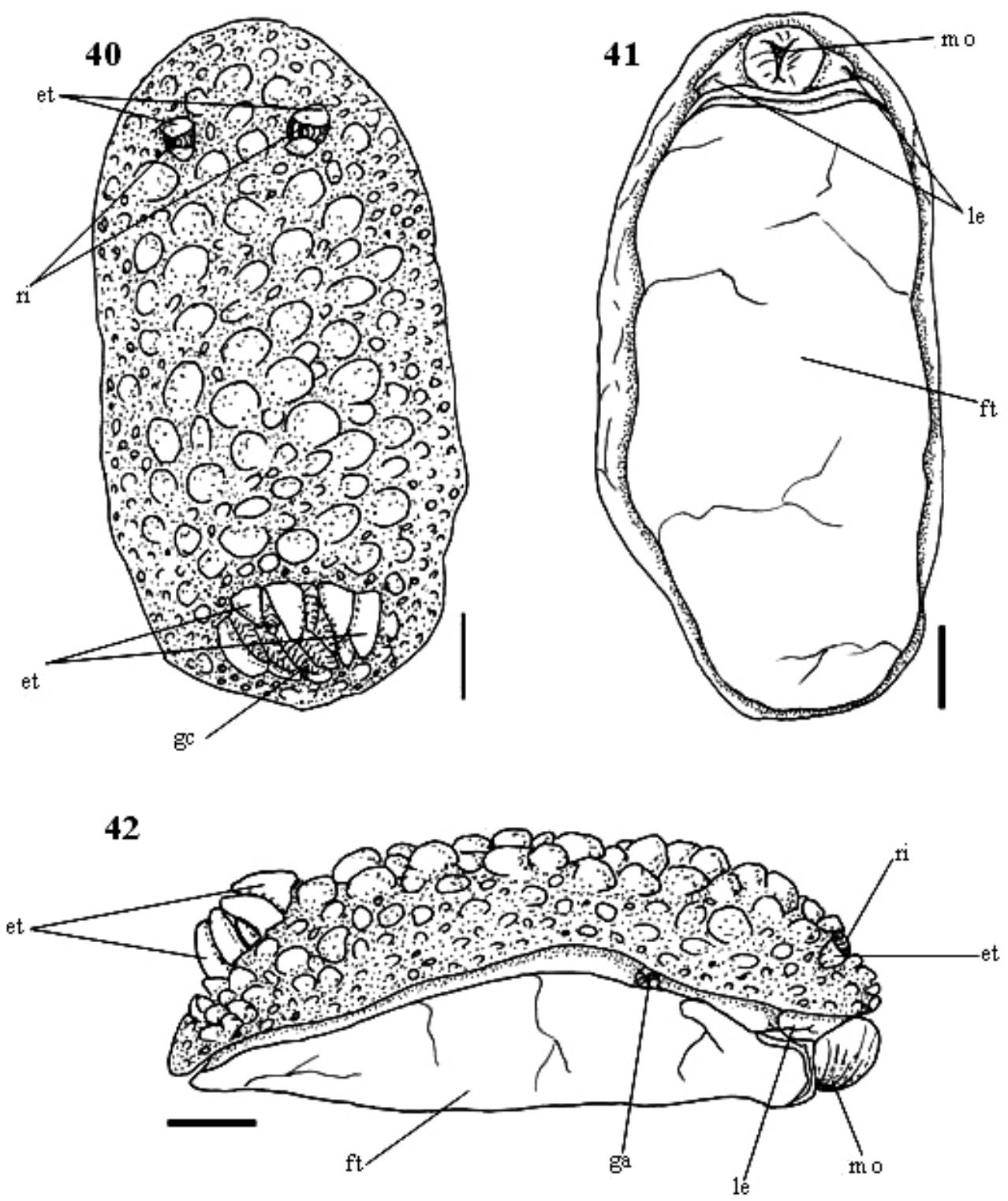

Figuras 40-42. Morfologia externa de Doris januarii. 40. Vista dorsal. 41. Vista ventral. 42. Vista lateral direita. Escala: $2 \mathrm{~mm}$. Abreviaturas: et: tubérculos alongados; ft: pé; ga: abertura genital; gc: círculo branquial; le: extensão lateral - prolongamentos orais mo: boca; pa: papila ri: rinóforo. 

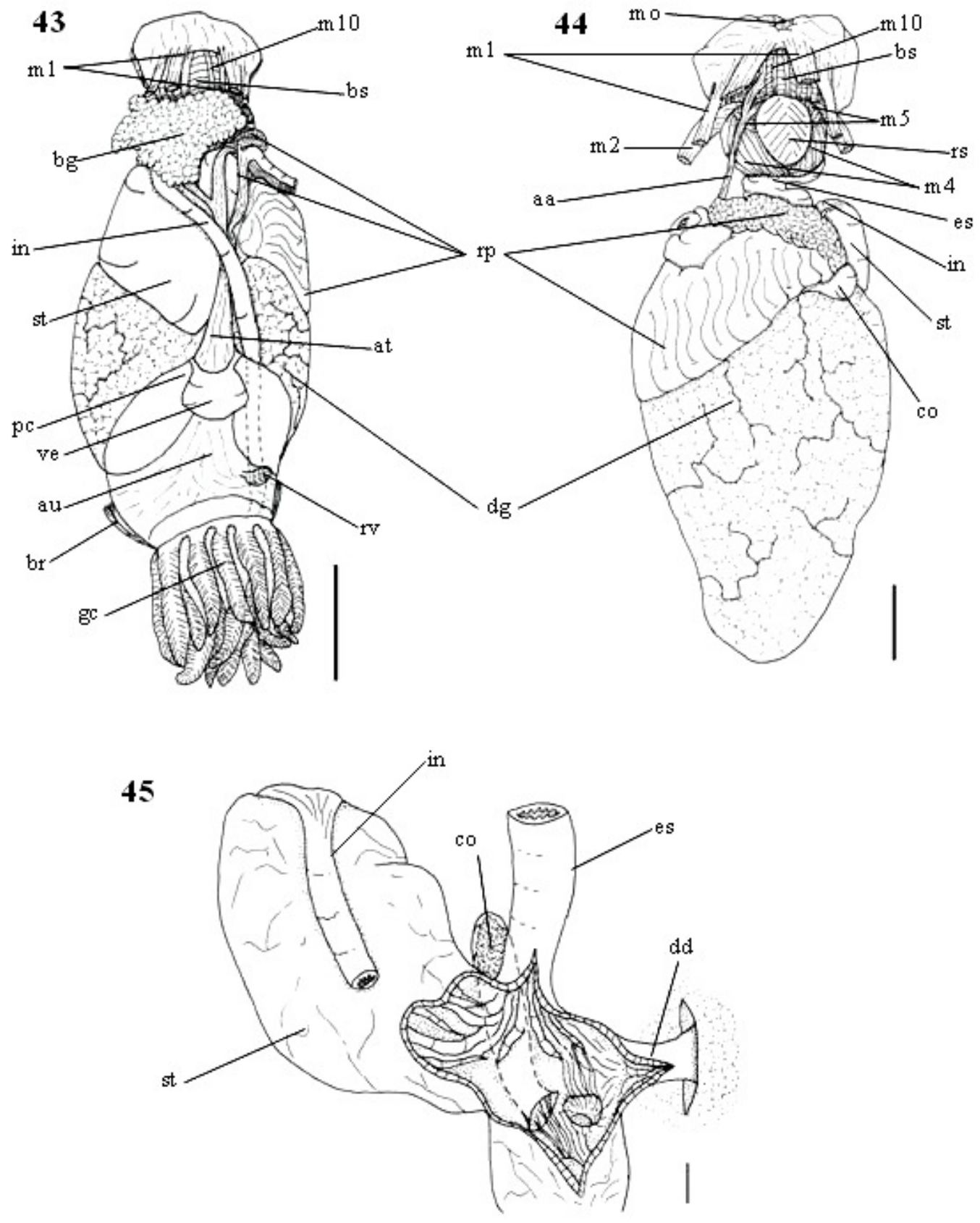

Figuras 43-44. Estrutura da hemocela de Doris januarii. 43. Vista dorsal. 44. Vista ventral. Escala: 2 mm. 45. Sistema digestivo médio, vista ventral, com aberturas para a glândula digestiva. Escala: $1 \mathrm{~mm}$. Abreviaturas: aa: aorta anterior; at: tronco aórtico; bg: glândula de sangue; bs: esfíncter bucal; br: músculo retrator da brânquia; co: ceco; dd: ducto da glândula digestiva; dg: glândula digestiva; es: esôfago; gc: círculo branquial; in: intestino; m1: músculos retratores da massa bucal; m2-m10: músculos do odontóforo; mp: músculo do pênis; pc: pericárdio; rp: sistema reprodutor; rs: saco radular; rv: vesícula renal; st: estômago; ve: ventrículo. 

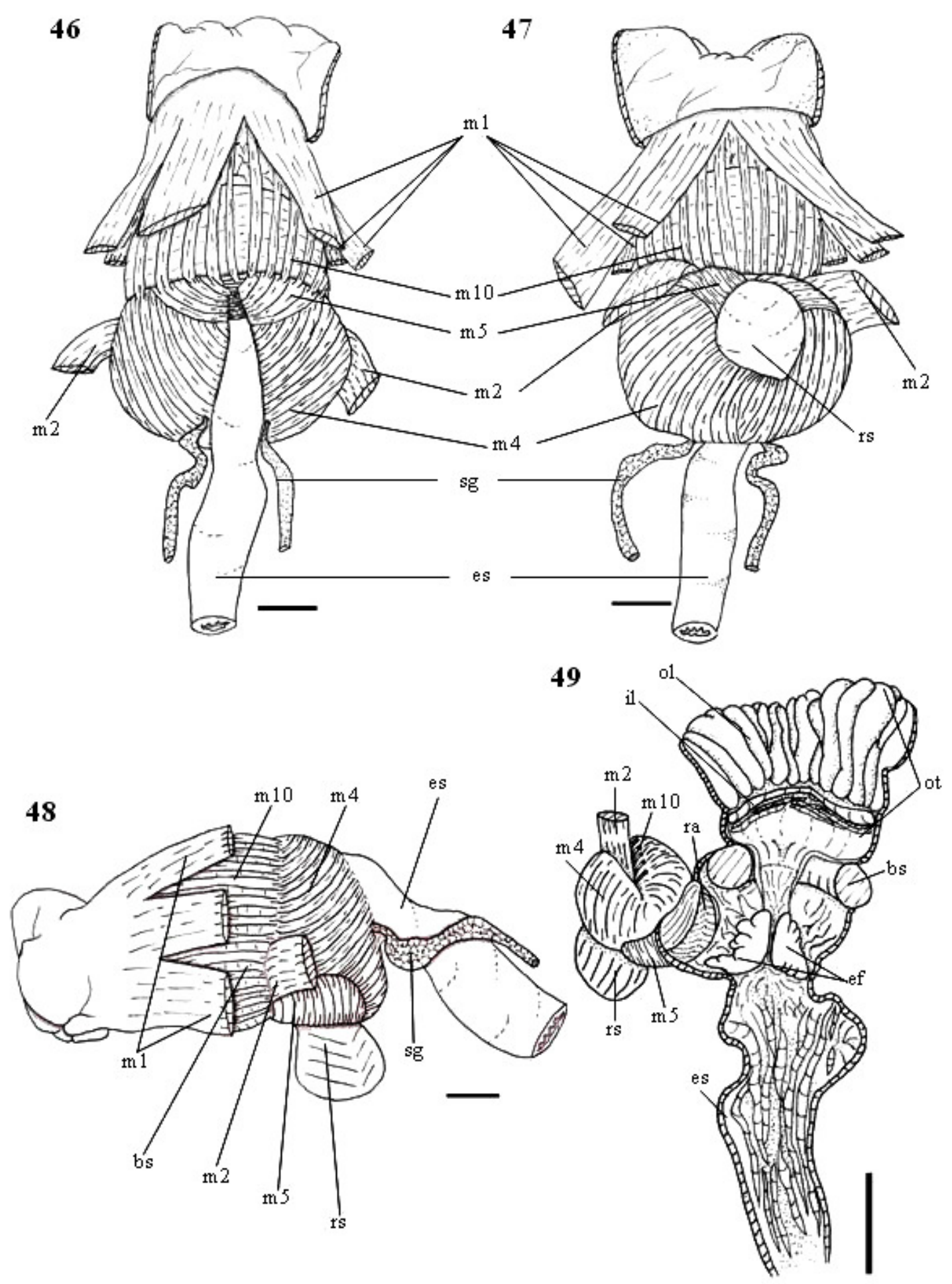

Figuras 46-49. Sistema digestivo anterior de Doris januarii. 46. Vista dorsal. 47. Vista ventral. 48. Vista lateral. 49. Vista ventral, corte longitudinal e odontóforo rebatido para o lado direito. Escalas: $2 \mathrm{~mm}$. Abreviaturas: bs: esfíncter bucal; ef: pregas esofágicas; es: esôfago; il: lábio interno; m1: músculos 
retratores da massa bucal; m2-m10: músculos do odontóforo; mo: boca; ol: lábio externo; ot: tubo oral; ra: rádula; rs: saco radular; sg: glândula salivar.
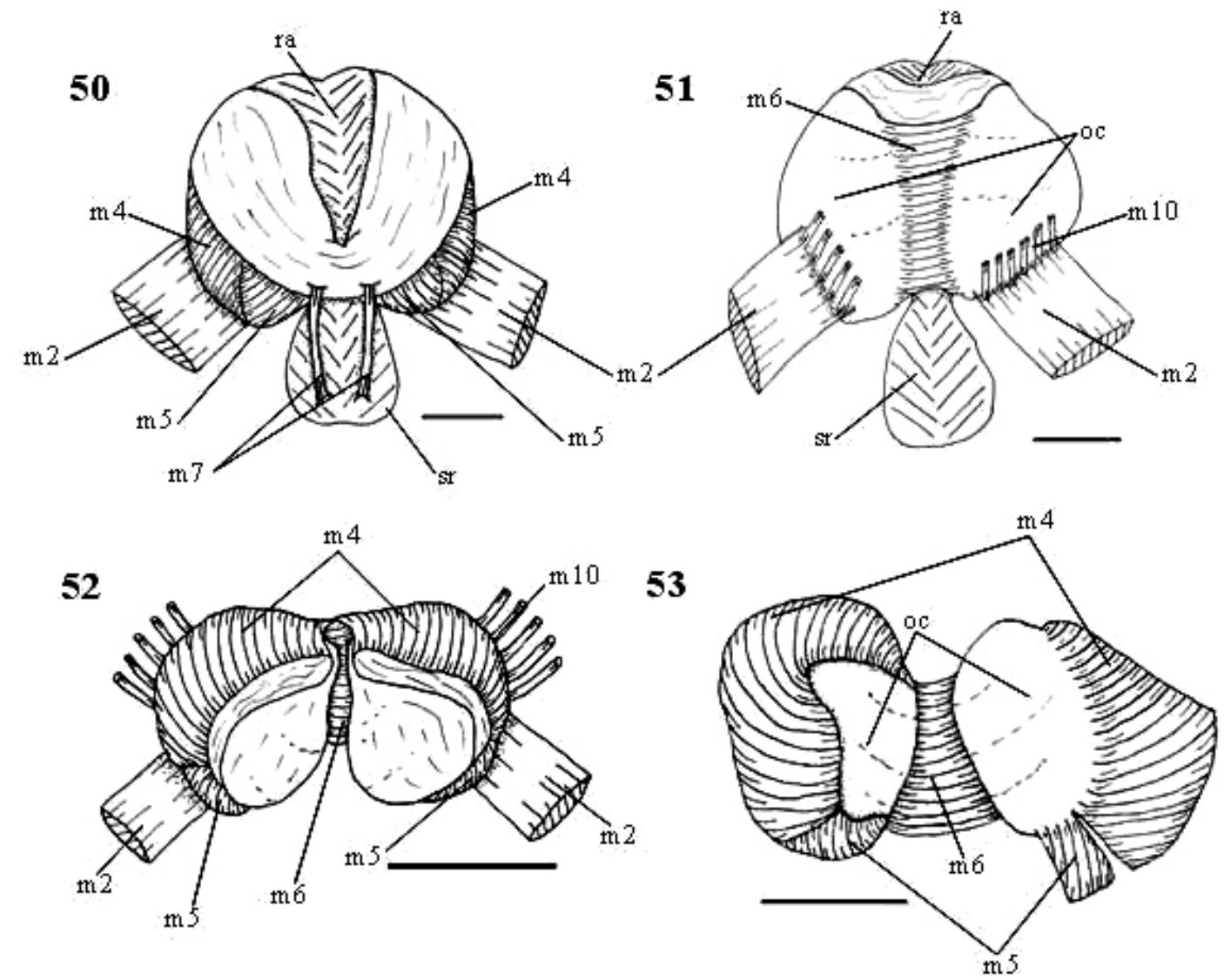

Figuras 50-53. Odontóforo de Doris januarii. 50. Vista ventral. 51. Vista dorsal. Escalas: 1 mm. 52. Vista ventral, rádula removida. 53. Vista ventral, m4 e m5 rebatidos com exposição da cartilagem do odontóforo. Escalas: $2 \mathrm{~mm}$. Abreviaturas: m2-m10: músculos do odontóforo; ra: radula; rs: saco radular. 

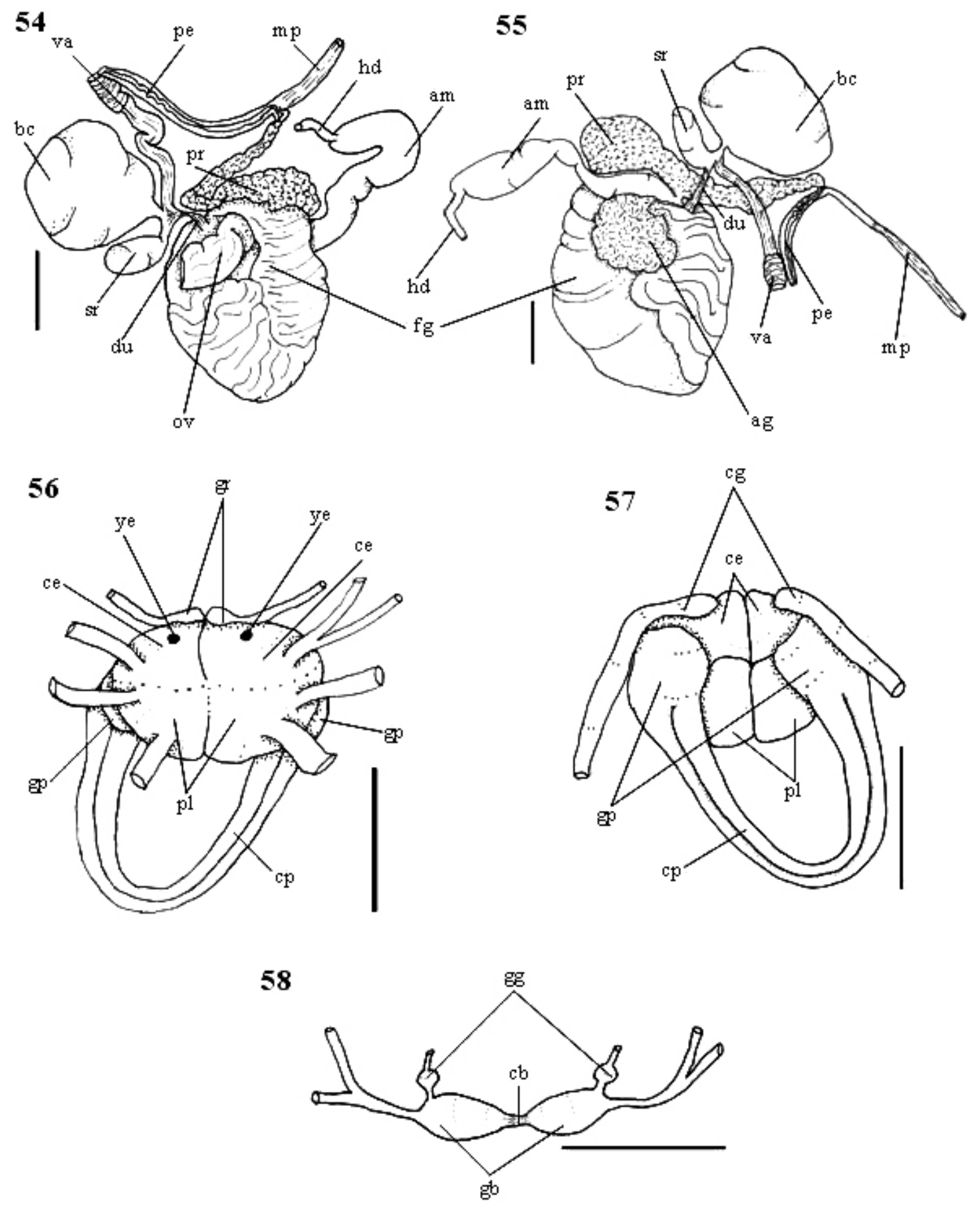

Figuras 54-58. Sistema reprodutor de Doris januarii. 54. Vista dorsal. 55. Vista ventral. Escalas: $2 \mathrm{~mm}$. 56-58. Sistema nervoso. 56. Vista dorsal. 57. Vista ventral. 58. Detalhe do gânglio bucal e gastroesofágico, vista ventral; Escalas: $1 \mathrm{~mm}$. Abreviaturas - ag: glândula de albúmen; am: ampola; bc: bursa copulatrix; cb: comissura bucal; ce: gânglio cerebral; cg: conectivo do gânglio bucal; cp: comissura pediosa; du: ducto uterino; fg: glândula feminina; gb: gânglio bucal; gg: gânglio gastro-esofágico; gp: gânglio pedioso; gr: gânglio rinoforal; hd: ducto hermafrodita; pe: pênis; pl: gânglio pleural; pr: próstata; sr: receptáculo seminal; va: vagina; ye: olhos. 


\section{Doris bovena Marcus, 1955}

(Figs. 59-85)

Doris bovena Marcus, 1955: 131-134, figs. 109-118; Marcus \& Marcus, 1963: 26-27;

Marcus \& Marcus, 1970: 60, fig. 1; Marcus, 1977: 10; Valdés, et. al., 2006: 170-

171; Amaral, et. al. 2010: 235.

Material tipo: não encontrado.

Localidade-tipo. Ilha Bela, São Sebastião, São Paulo, Brasil.

Material examinado: BRASIL, Rio de Janeiro, Cabo Frio, Canal do Itajurú, MZSP 96902, 2 ex. (V. Padula col., 01/IX/2008). São Paulo, São Sebastião, MZSP 25309, 01 ex. Sem localidade, MZSP 75958, 01 ex.; MZSP 76198, 7 ex.; MZSP 76246, 8 ex.

\section{Redescrição}

Morfologia externa (Figs. 59; 61-62; 66-70): Tamanho 4-7-13 mm de comprimento. Coloração amarela acinzentada, com duas manchas mais escuras no centro do noto. Corpo amplamente ovoide, anterior e posteriormente da mesma forma, pé mais pontiagudo posteriormente. Noto coberto por tubérculos de diferentes tamanhos, mas intercalados os maiores com os menores. Rinóforos com cerca de 10 lamelas e a borda da cavidade rinoforal rodeada por papilas. Brânquias unipinadas com aproximadamente 10 filamentos, dispostos de forma circular borda da cavidade também apresentam papilas. Ânus localizado na região central das brânquias e possui uma papila. A boca é um poro que divide os dois tentáculos orais que apresentam formato de "barril" com sulco lateral em cada um deles. 
Hemocela (Figs. 71-72): A topografia geral do animal segue o padrão das espécies anteriores. Massa visceral coberta por uma fina membrana conectada com a superfície interna do noto e com o pericárdio, no $1 / 3$ posterior da massa visceral. Sistema nervoso dorsal ao aparato bucal, mais posterior do que em $D$. verrucosa, e coberto pela glândula de sangue.

Sistema circulatório e excretor (Figs. 70-71): segue o mesmo padrão das espécies descritas anteriormente. Músculo retrator da brânquia presente. Ventrículo com formato globoso. As proporções entre ventrículo, aurícula e vesícula renal não foram analisadas, pois os exemplares dissecados não estavam em bom estado de conservação. Brânquias com lamelas aproximadamente três vezes mais largas e em menor quantidade do que em D. januarii.

Sistema digestivo (Figs. 73-80): Aparato bucal ocupando cerca de 20\% da massa visceral. Tubo oral mais curto do que o da espécie anterior, lábio externo com pregas mais curtas e grossas e em menor quantidade e o lábio interno com uma prega transversal. Odontóforo com características semelhantes às espécies anteriores com as seguintes diferenças: m5) com $1 / 2$ do tamanho e $2 / 3$ da largura do $\mathrm{m} 4$, segue até metade da cartilagem do odontóforo, circunda o saco radular; m6) com porção anterior e posterior na mesma largura. $\mathrm{O}$ par de cartilagens do odontóforo apresenta o mesmo formato elíptico que em $D$. verrucosa e $D$. januarii. Saco radular ocupa cerca de $1 / 3$ do tamanho total do odontóforo. Dentes radulares (Figs. 63-65): fórmula radular 23 fileiras com 27.0.27 dentes, em um exemplar com $4 \mathrm{~mm}$ de comprimento e 32 fileiras com 43.0.43 dentes, em um exemplar com $7 \mathrm{~mm}$ de comprimento, todos os dentes são lisos e com uma cúspide simples e em formato de gancho. Esôfago segue o mesmo padrão das espécies anteriores. Par de glândulas salivares tubulares e longa, com cerca de 1/2 da largura da glândula nas espécies anteriores, conectada com a região anterior do esôfago 
e se estende até a região anterior da glândula digestiva. Estômago oval, ocupando aproximadamente $20 \%$ da massa visceral, junto com o ceco, superfície interna toda pregueada, com uma quantidade menor de pregas longitudinais e mais grossas em todo o estômago, do que em D. verrucosa e D. januarii. Apresenta um abaulamento sutil entre o estômago e o intestino. Na porção posterior que se afunila e segue para o intestino as pregas são mais finas, cerca de $1 / 2$ da largura das pregas no estômago. Ceco com formato reniforme, aproximadamente o mesmo tamanho e $1 / 2$ da largura do estômago. Intestino mantém o padrão das espécies anteriores. Glândula digestiva ocupa cerca de $50 \%$ da massa visceral, com formato cônico com a porção anterior duas vezes mais larga do que a posterior, aspecto esponjoso da face interna, com um ducto digestivo principal.

Sistema reprodutor (Figs. 81-82): segue o padrão das espécies já descritas. Ocupa $15 \%$ da massa visceral. Ampola alongada, com cerca de duas vezes a largura e aproximadamente o mesmo comprimento da próstata. Próstata tubular, glandular se transformando direto no pênis. Ducto deferente e músculo do pênis ausentes. Pênis com 1/3 do tamanho da próstata. Gônada imersa na glândula digestiva, como em $D$. verrucosa e D. januarii. Glândula feminina bem desenvolvida, arredondada, irregular, ocupa $60 \%$ do sistema reprodutor, está dividida em glândula mucosa, ocupando $2 / 3$ e com coloração bege, e glândula de albúmen que ocupa 1/3 da região mais anterior, dilatado com formato irregular e com uma coloração marrom escuro. Oviduto com aproximadamente 1/6 do tamanho da glândula feminina. Ducto uterino aproximadamente duas vezes mais longo do que em $D$. januarii. Receptáculo seminal e bursa copulatrix aproximadamente com o mesmo tamanho e formato. Vagina com o mesmo comprimento e metade do diâmetro do pênis. 
Sistema nervoso (Figs. 71; 83-85): ocupa cerca de 1/10 da hemocela. Semelhante à espécie anterior, levemente mais posterior ao odontóforo, na parte anterior do esôfago, com glândula de sangue cobrindo parcialmente o sistema nervoso, não todo, como em D. verrucosa. Par de gânglios cerebrais e pleurais parcialmente fundidos, distintos do par de gânglios pediosos. Gânglios pediosos conectados através da comissura pediosa, também dupla, sendo uma comissura duas vezes mais fina que a outra e seis vezes mais curta do que em D. januarii. Gânglios bucais, localizados na porção ventral e anterior do esôfago, praticamente fundidos com uma comissura muito curta, quase imperceptível, estão conectados com gânglios cerebrais através de um longo e delgado conectivo, e com os gânglios gastro-esofágicos por um conectivo curto. Gânglios gastro-esofágicos, cerca de 1/5 do tamanho do gânglio bucal, com formato circular. Gânglios rinoforais com formato de bulbo, conectados com a porção anterior dos gânglios cerebrais, no entanto mais separados do que em $D$. verrucosa. . Olhos dorsais, situados nos gânglios cerebrais, mas separados como em D. verrucosa. Estatocistos localizados interiormente aos gânglios pediosos, pequenos e iridescentes.

Distribuição: da Flórida a São Paulo. Regiões confirmadas: Flórida (EUA); Aruba e Curaçao (Ilhas ABC); Rio de Janeiro e São Paulo (Brasil).

Habitat: vive sob rochas na região infralitoral. 

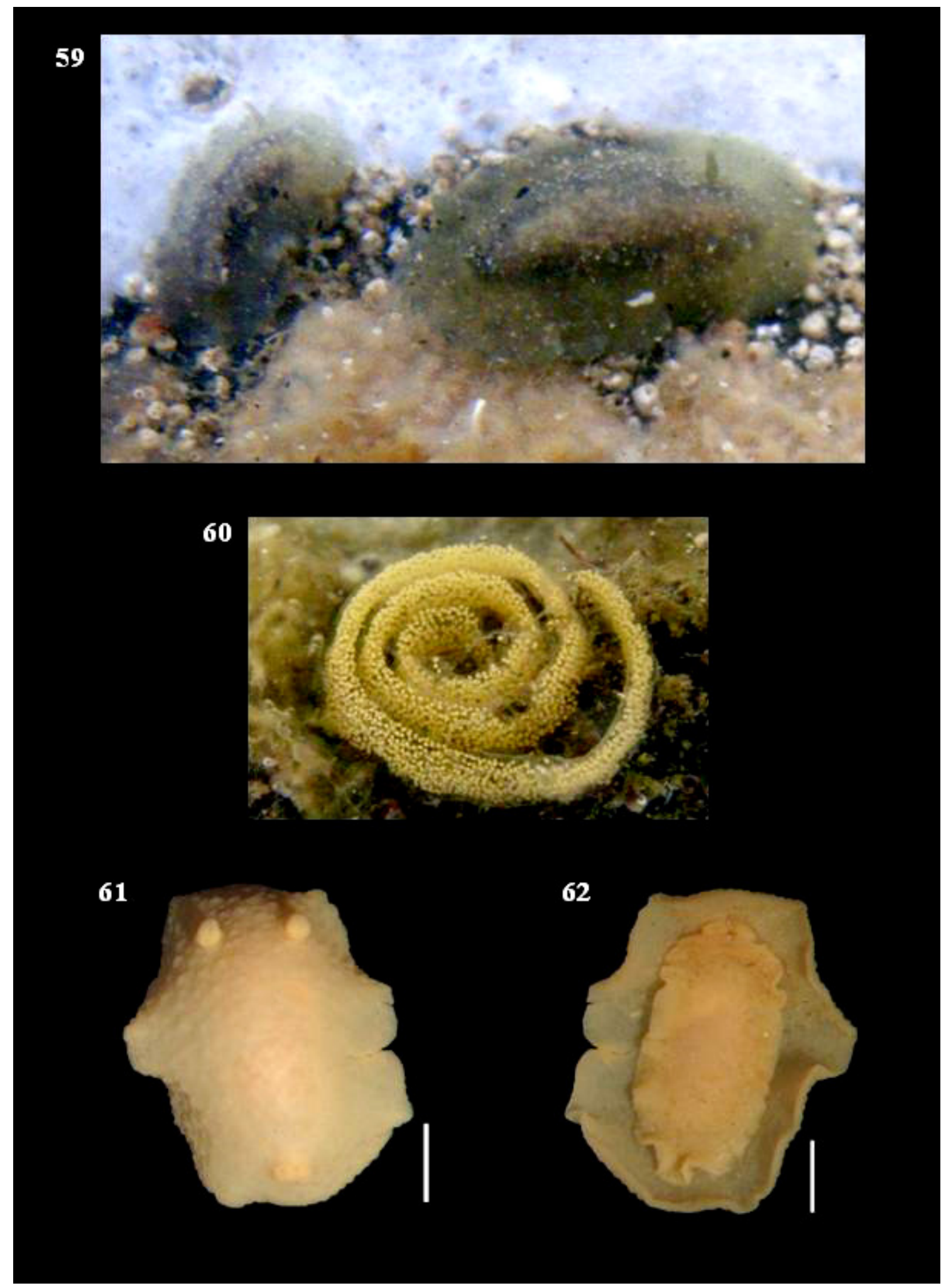

Figuras 59-62 Doris bovena. 59. Morfologia externa, in vivo (MZSP 96902). 60. Postura. 61. Vista dorsal animal fixado. 40. Vista ventral animal fixado (MZSP 75958). Escala: $1 \mathrm{~mm}$. 


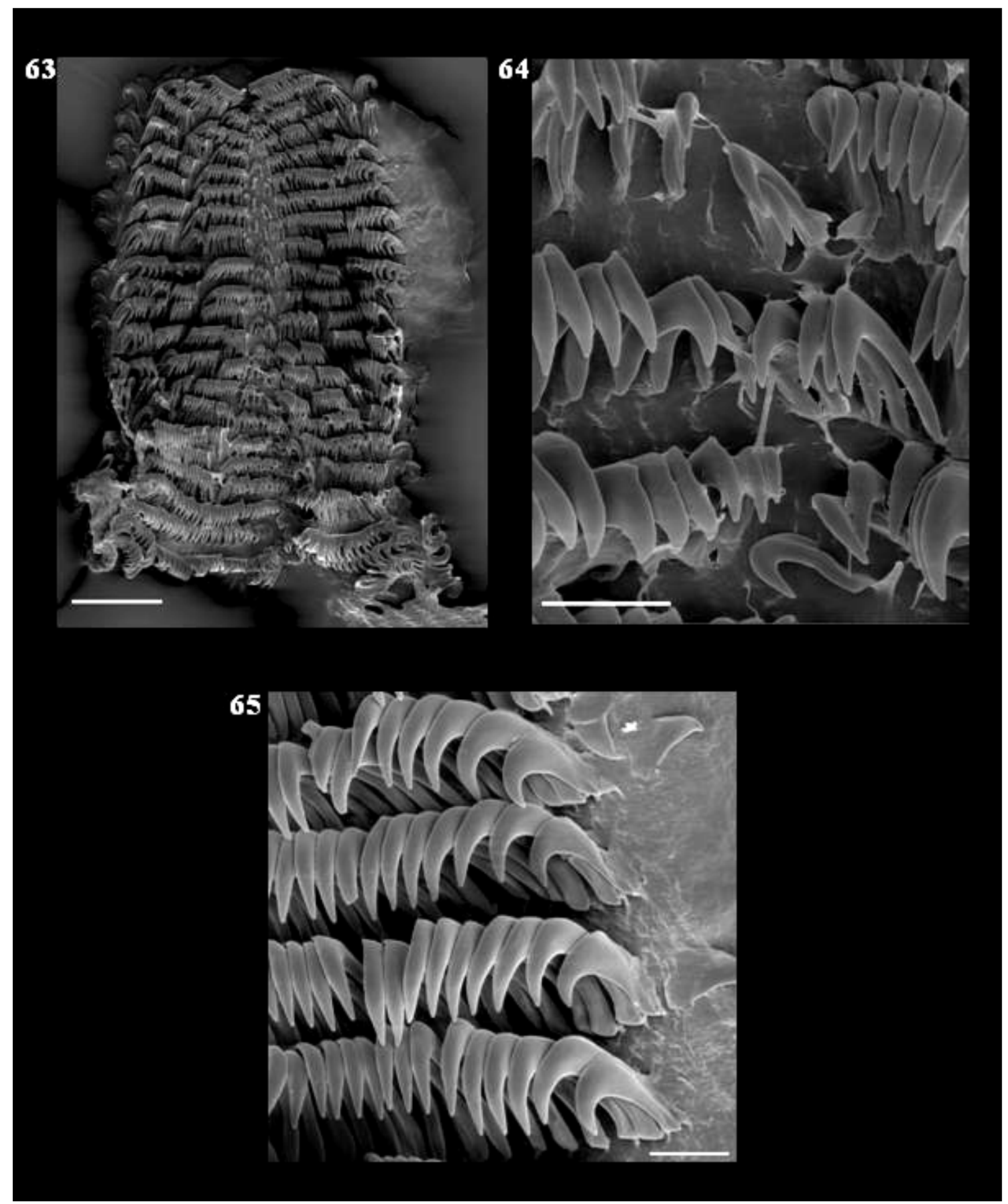

Figuras 63-65. Doris bovena. Microscopia eletrônica da rádula (MZSP 75958). 63. Vista panorâmica da rádula. Escala: $100 \mu \mathrm{m}$. 64. Vista central dos dentes laterais mais internos. 65. Vista dos dentes laterais mais externos. Escalas: $20 \mu \mathrm{m}$. 

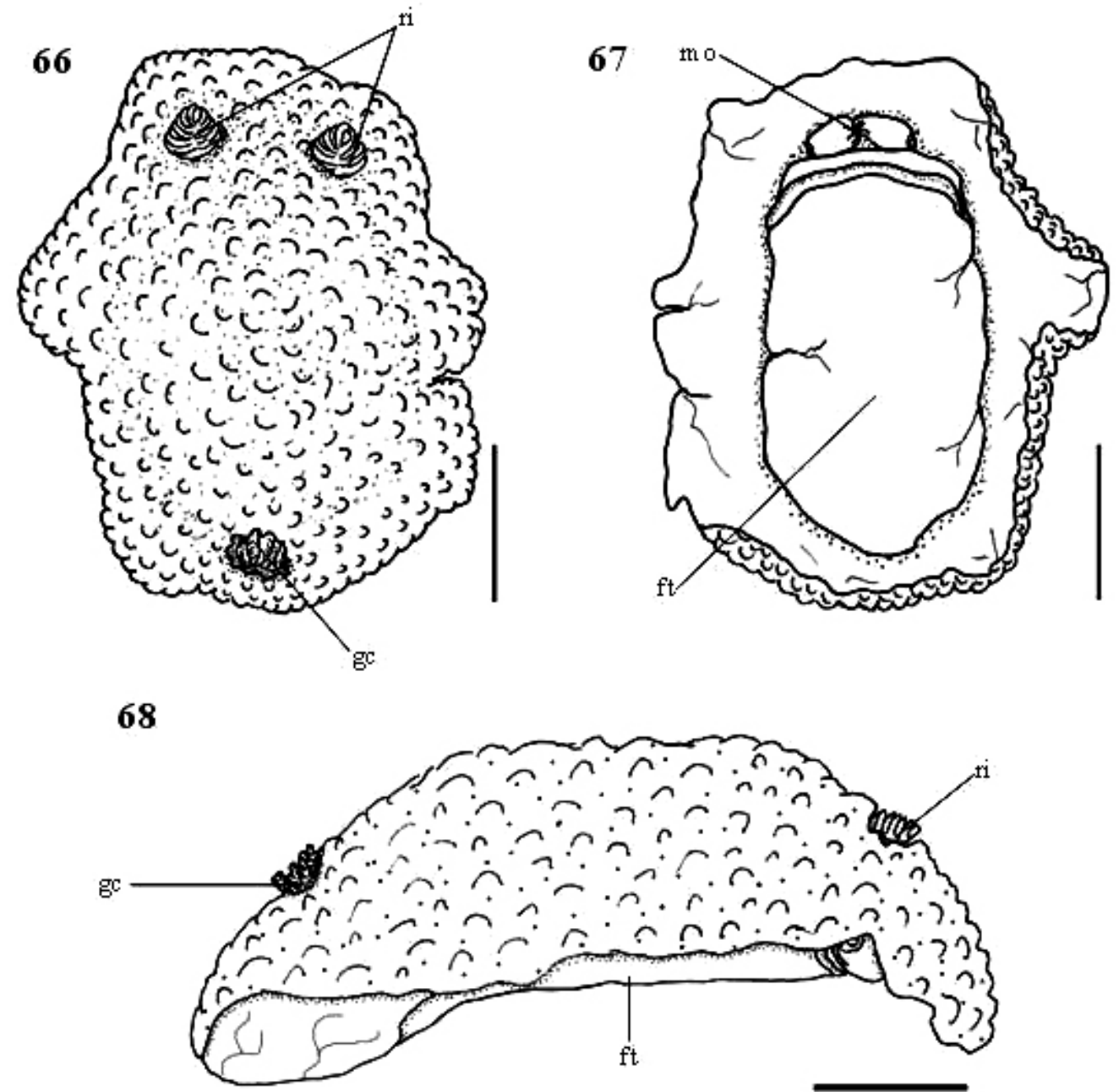

69

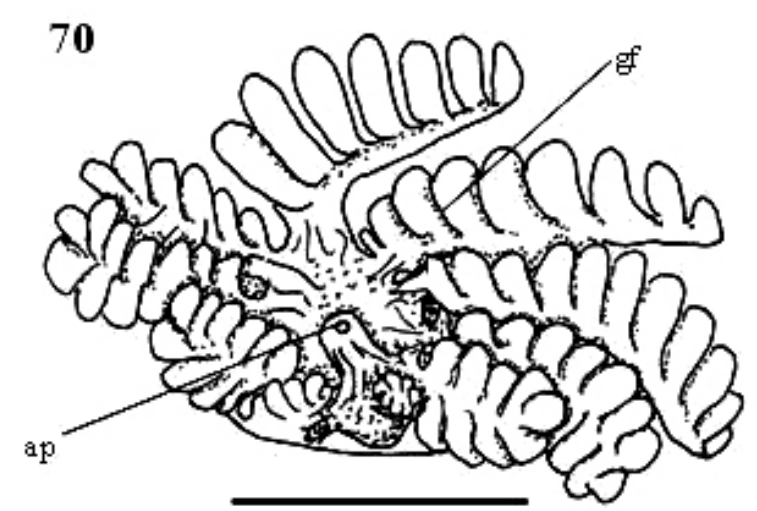

Figuras 66-70. Morfologia externa de Doris bovena. 66. Vista dorsal. 67. Vista ventral. 68. Vista lateral direita. Escalas: $1 \mathrm{~mm}$. 69. Detalhe da cavidade do rinóforo, vista dorsal. 70. Círculo branquial, vista dorsal. Escalas: $0,5 \mathrm{~mm}$. Abreviaturas - ap: papila anal; ft: pé; gc: círculo branquial; gf: filamento branquial; mo: boca; ri: rinóforo. 

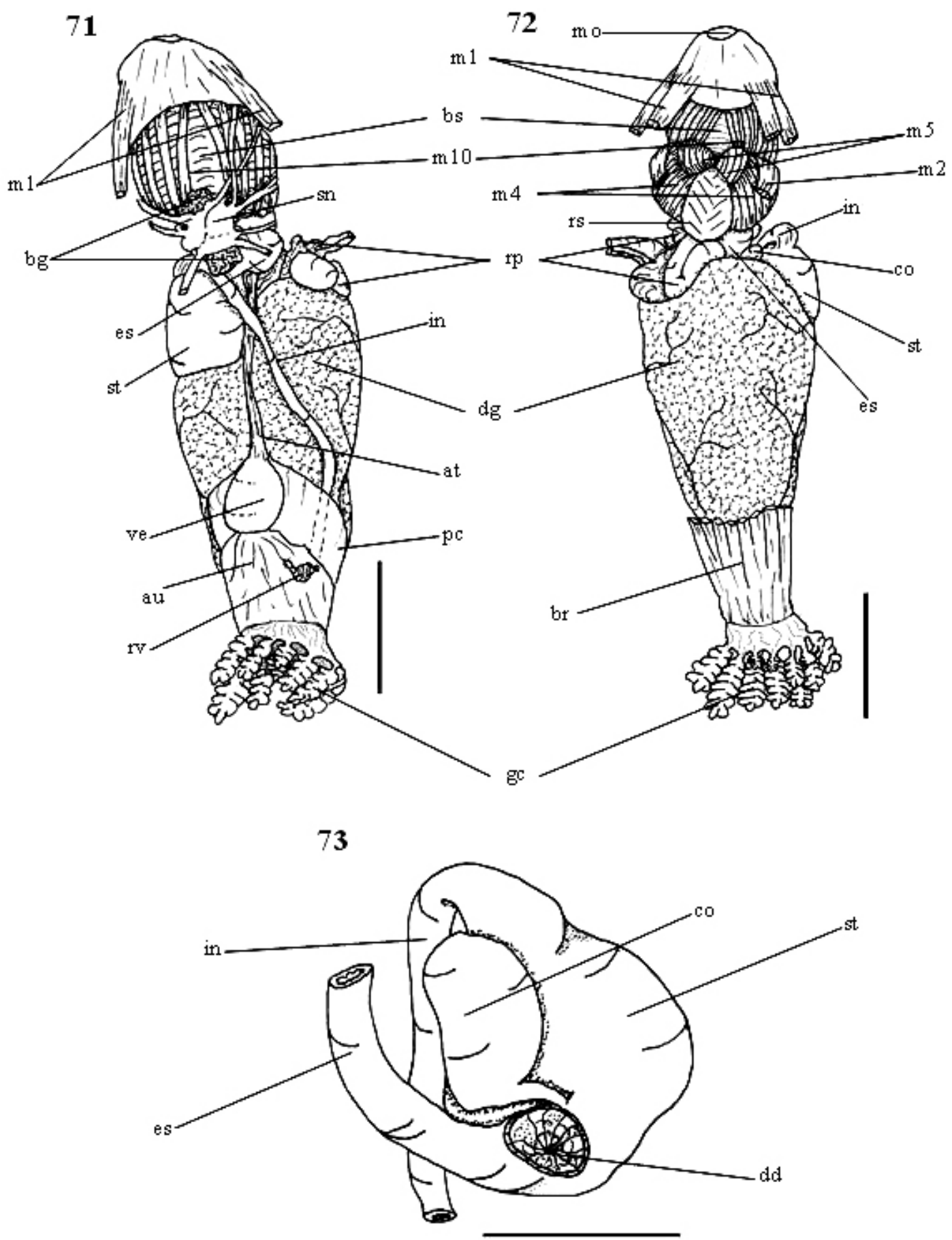

Figuras 71-73. Estruturas da hemocela de Doris bovena. 71. Vista dorsal. 72. Vista ventral. 73. Sistema digestivo médio, vista ventral. Escalas: $1 \mathrm{~mm}$. Abreviaturas: au: aurícula; bg: glândula de sangue; bm: massa bucal; br: músculo retrator da brânquia; co: ceco; dd: ducto da glândula digestiva; dg: glândula digestiva; es: esôfago; gc: círculo branquial; in: intestino; mo: boca; pc: pericárdio; rp: sistema reprodutor; rs: saco radular; rv: vesícula renal; sn: sistema nervoso; st: estômago; ve: ventrículo. 

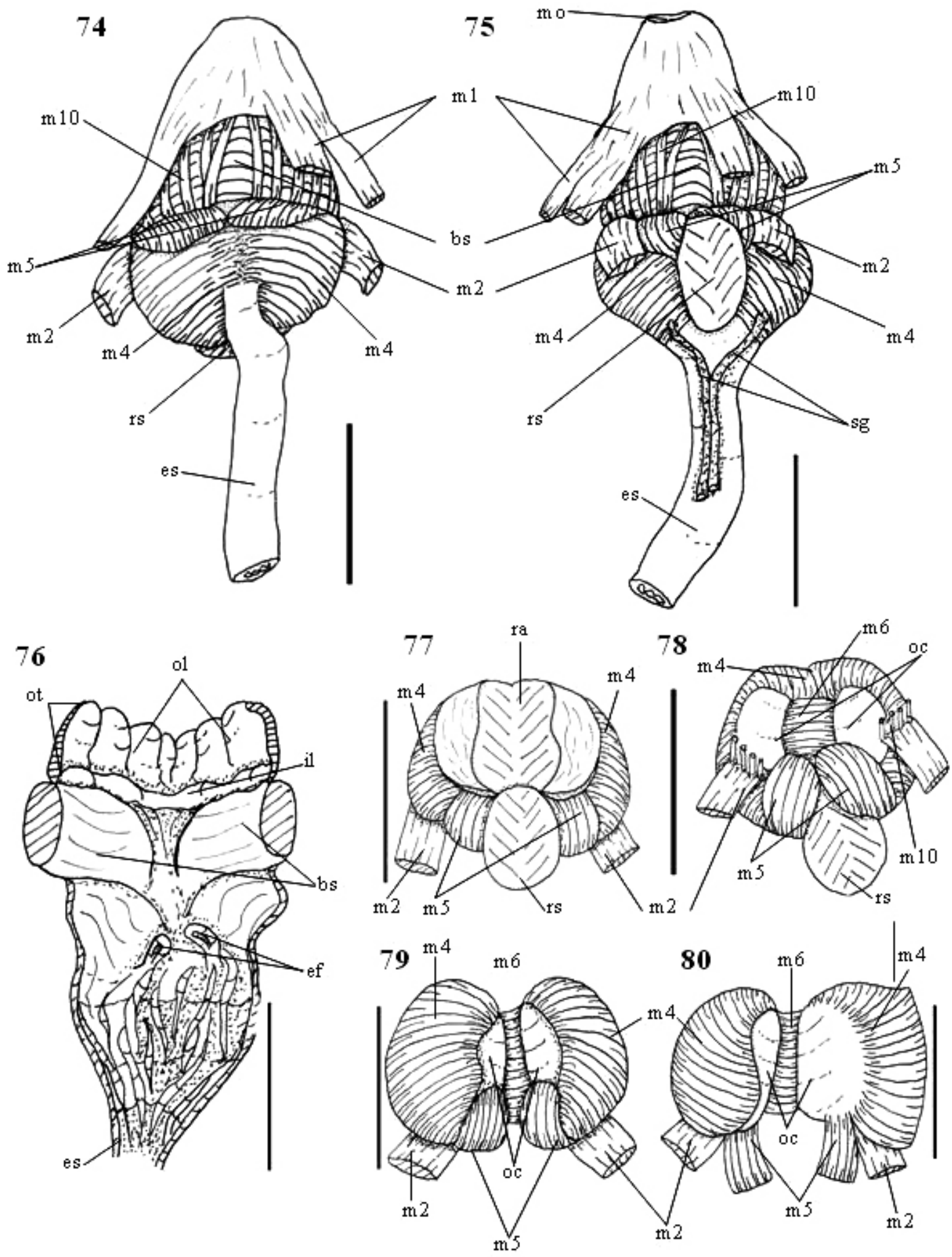

Figuras 74-76. Sistema digestivo anterior de Doris bovena. 74. Vista dorsal. 75. Vista ventral. 76. Vista ventral, corte longitudinal e odontóforo removido. 77-80. Odontóforo de Doris bovena. 77. Vista ventral. 78. Vista dorsal. 79. Vista ventral, rádula removida. 80. Vista ventral, $\mathrm{m} 4 \mathrm{e} \mathrm{m} 5$ rebatidos com exposição da cartilagem do odontóforo. Escalas: $1 \mathrm{~mm}$. Abreviaturas: bs: esfíncter bucal; ef: pregas essofágicas; es: esôfago; il: lábio interno; m1: músculos retratores da massa bucal; m2-m10: músculos do odontóforo; mo: boca; oc: cartilagem do odontóforo; ol: lábio externo; ot: tubo oral; ra: rádula; rs: saco radular. 

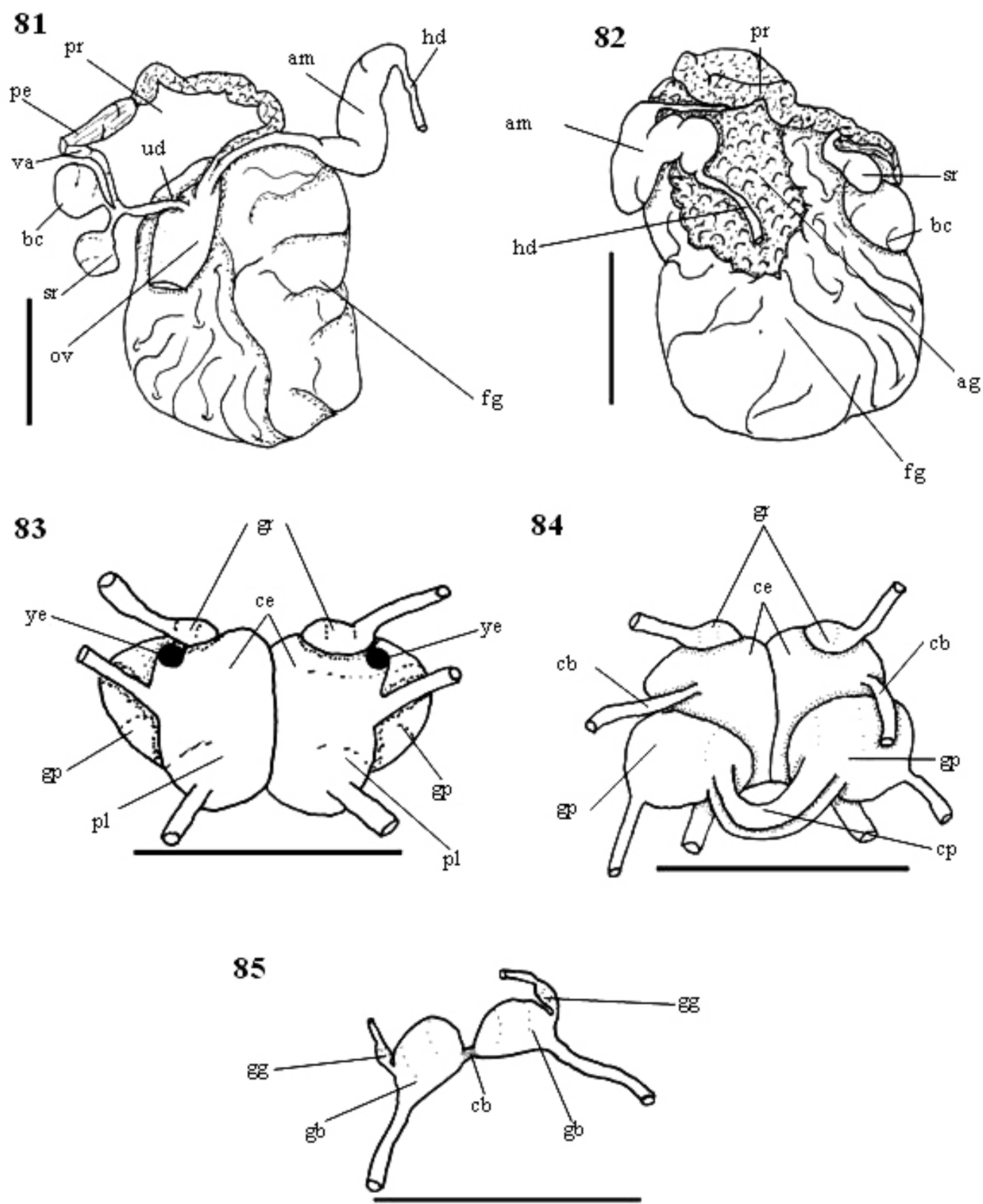

Figuras 81-82. Sistema reprodutor de Doris bovena. 81. Vista dorsal. 82. Vista ventral. 83-85. Sistema nervoso de Doris bovena. 83. Vista dorsal. 84. Vista ventral. 85. Detalhe do gânglio bucal e gastroesofágico, vista ventral. Escalas: $1 \mathrm{~mm}$. Abreviaturas - ag: glândula de albúmen; am: ampola; bc: bursa copulatrix; cb: comissura bucal; cc: comissura circuesofágica; ce: gânglio cerebral; cg: conectivo do gânglio bucal; fg: glândula feminina; gb: gânglio bucal; gg: gânglio gastro-esofágico; gp: gânglio pedioso; gr: gânglio rinoforal; hd: ducto hermafrodita; pe: pênis; pl: gânglio pleural; pr: próstata; sr: receptáculo seminal; va: vagina. 
(Figs. 86-112)

Siraius ilo Marcus, 1955: 135-137 (fig.119-125); Marcus \& Marcus, 1970: 61; Marcus, 1977: 10 .

Doris ilo: Valdés 2002: 560; Valdés et. al. 2006: 170-171.

Material tipo: não localizados.

Localidade-tipo. Ilha de São Sebastião, Ilhabela, São Paulo, Brasil.

Material examinado: BRASIL, Rio de Janeiro, Cabo Frio, MZSP 25349, 01 ex. (vii/1957); São Paulo, São Sebastião, MZSP 25350, 01 ex.; MZSP 102801, 01 ex. (P. Lima col., 12/xii/2011); Sem localidade, MZSP 76237, 02 ex.

\section{Redescrição}

Morfologia externa (Figs. 86; 88-89; 93-97): Tamanho 6-9-15 mm. Cor do animal amarelo acinzentado, com tubérculos que cobrem o noto de cor escura. Corpo achatado. Tubérculos planos de tamanhos diferentes. Rinóforos com 15 lamelas, da mesma coloração geral do animal, com a borda das cavidades irregulares pela presença de pequenos tubérculos. Brânquia com 22 filamentos unipinados, dois filamentos mais anteriores unidos em suas bases e os mais posteriores avançam para o centro do círculo branquial, borda da cavidade branquial é também irregular com pequenos tubérculos. Tentáculos orais em forma de barril com um sulco no lado externo, como em $D$. bovena, mas com um formato mais triangular e a boca delimita em formato circular. Borda anterior do pé sulcada. 
Hemocela (Figs. 98-99): A topográfica geral do animal segue o padrão das espécies anteriores. Massa visceral coberta por uma fina membrana conectada com a superfície interna do noto e com o pericárdio, no $1 / 4$ posterior da massa visceral. Sistema nervoso dorsal ao aparato bucal, mais posterior do que em $D$. verrucosa e $D$. januarii, e coberto pela glândula de sangue dividida, como em $D$. bovena.

Sistema circulatório e excretor (Fig. 98): como descrito em D. verrucosa com algumas diferenças: ventrículo com formato mais triangular, cerca de $1 / 3$ maior do que em D. verrucosa. Músculo retrator da brânquia presente. Aorta parece apresentar três ramos, um que segue pela glândula digestiva, e os outros dois que seguem como em $D$. verrucosa. Vesícula renal com aproximadamente 1/3 do tamanho ventrículo.

Sistema digestivo (Figs. 101-107): tubo oral semelhante ao de D. verrucosa, com lábio superior com pregas longitudinais e lábio inferior com uma prega transversal. Odontóforo com características similares às descritas para as espécies anteriores, com as seguintes diferenças: m1) mais finos, cerca de metade da largura dos descritos para $D$. verrucosa e $D$. januarii; $\mathbf{m 5}$ ) é mais alongado do que em $D$. verrucosa, cobrindo toda a parte interna da cartilagem do odontóforo; m6) apresenta a porção posterior duas vezes mais larga que a anterior, também com formato de "funil", como em $D$. verrucosa. m7a) par de músculos relativamente curtos e muito finos com origem na porção posterior do m6, seguem paralelos, posterior e ventralmente para inserir na região mediana do saco radular. Cartilagem do odontóforo mais alongada do que elíptica. Dentes radulares (Figs. 90-92): fórmula radular variando de 22 fileiras com 21.0.21 dentes, em um exemplar com $8 \mathrm{~mm}$ de comprimento, e 30 fileiras com 2.34.0.34.2 dentes, em um exemplar com $12 \mathrm{~mm}$ de comprimento, o dente lateral é liso, com uma cúspide simples e sem dentículos, os dentes mais externos são lisos e todos em formato de gancho, como nas espécies anteriores. Esôfago 1/3 mais fino do que em $D$. januarii. 
Glândula salivar não foi visualizada. Estômago oval, ocupando aproximadamente 10\% da massa visceral, superfície interna com pregas irregulares centrais e pregas longitudinais e mais grossas no abaulamento que antecede o intestino, com uma abertura para o ducto da glândula digestiva e uma abertura comum no ponto em que se inserem o esôfago e o ceco. Entre o estômago e o intestino há um abaulamento, mais definido do que em $D$. bovena. Intestino mais alongado do que em $D$. januarii, sigmóide e com pregas longitudinais em toda sua extensão, originado na parte posterior do abaulamento do estômago, diâmetro menor do que o do esôfago, aproximadamente $1 / 2$, porém mais uniforme. Ceco com cerca de $2 / 3$ do tamanho do estômago, com $1 / 3$ da largura e com um afunilamento na porção que se insere com a área comum entre esôfago e estômago. Glândula digestiva segue o mesmo padrão de $D$. verrucosa e $D$. januarii, ocupando cerca de $60 \%$ da massa visceral, com formato cônico com a porção anterior duas vezes mais larga do que a posterior, com um ducto principal.

Sistema reprodutor (Figs. 108-109): mantém o padrão das espécies anteriores. Ampola com 2/3 do comprimento e cerca de duas vezes o diâmetro da próstata. Próstata mais alongada que das espécies anteriores e não glandular $1 / 3$ mais comprida e com 1/2 do diâmetro da ampola. Pênis bojudo, cerca de duas vezes a largura e aproximadamente o mesmo comprimento da vagina. Duto deferente curto, aproximadamente $1 / 3$ do tamanho da vagina. Músculo do pênis ausente, como D. bovena. Gônada imersa na glândula digestiva. Glândula feminina bem desenvolvida, arredondada, irregular, ocupa $80 \%$ do sistema reprodutor dividida em: glândula mucosa ocupa 3/4 da glândula feminina e apresenta uma coloração bege, e glândula de albúmen que ocupa 1/4 anterior e é mais dilatado, com formato irregular e com uma coloração marrom escuro. Oviduto com aproximadamente $1 / 5$ do tamanho da glândula feminina. Ducto uterino aproximadamente duas vezes mais longo do que em $D$. januarii. Receptáculo seminal 
com formato piriforme, cerca de $2 / 3$ do tamanho da bursa copulatrix. Bursa copulatrix também com formato piriforme. Vagina com 1/2 do diâmetro do pênis.

Sistema nervoso (Figs. 98; 110-112): ocupa aproximadamente, 1/20 da hemocela; Semelhante às espécies anteriores com algumas diferenças: sutilmente localizada mais posteriormente, como em D. bovena. Glândula de sangue dividida em duas partes, como em $D$. bovena. Gânglios pediosos conectados através da comissura pediosa simples, aproximadamente $1 / 2$ do tamanho da comissura em $D$. verrucosa, porém duas vezes mais curta do que em $D$. januarii e duas vezes o tamanho de $D$. bovena. Gânglios bucais fundidos, conectados com gânglios cerebrais através de um longo e delgado conectivo, e com os gânglios gastro-esofágicos por um conectivo curto. Gânglios gastro-esofágicos, cerca de 1/6 do tamanho do gânglio bucal, com formato circular. Gânglios rinoforais seguem o padrão das espécies anteriores e estão mais distantes um do outro como em $D$ bovena. Olhos dorsais, situados nos gânglios cerebrais, parecem mais distantes um do outro do que em $D$. verrucosa e $D$. januarii. Estatocistos localizados interiormente aos gânglios pediosos, pequenos e iridescentes.

Distribuição: de Florida Keys a São Paulo. Regiões confirmadas: EUA: Florida: Florida Keys (EUA); Rio de Janeiro, São Paulo (Brasil).

Habitat: vive sob rochas na região infralitoral. 


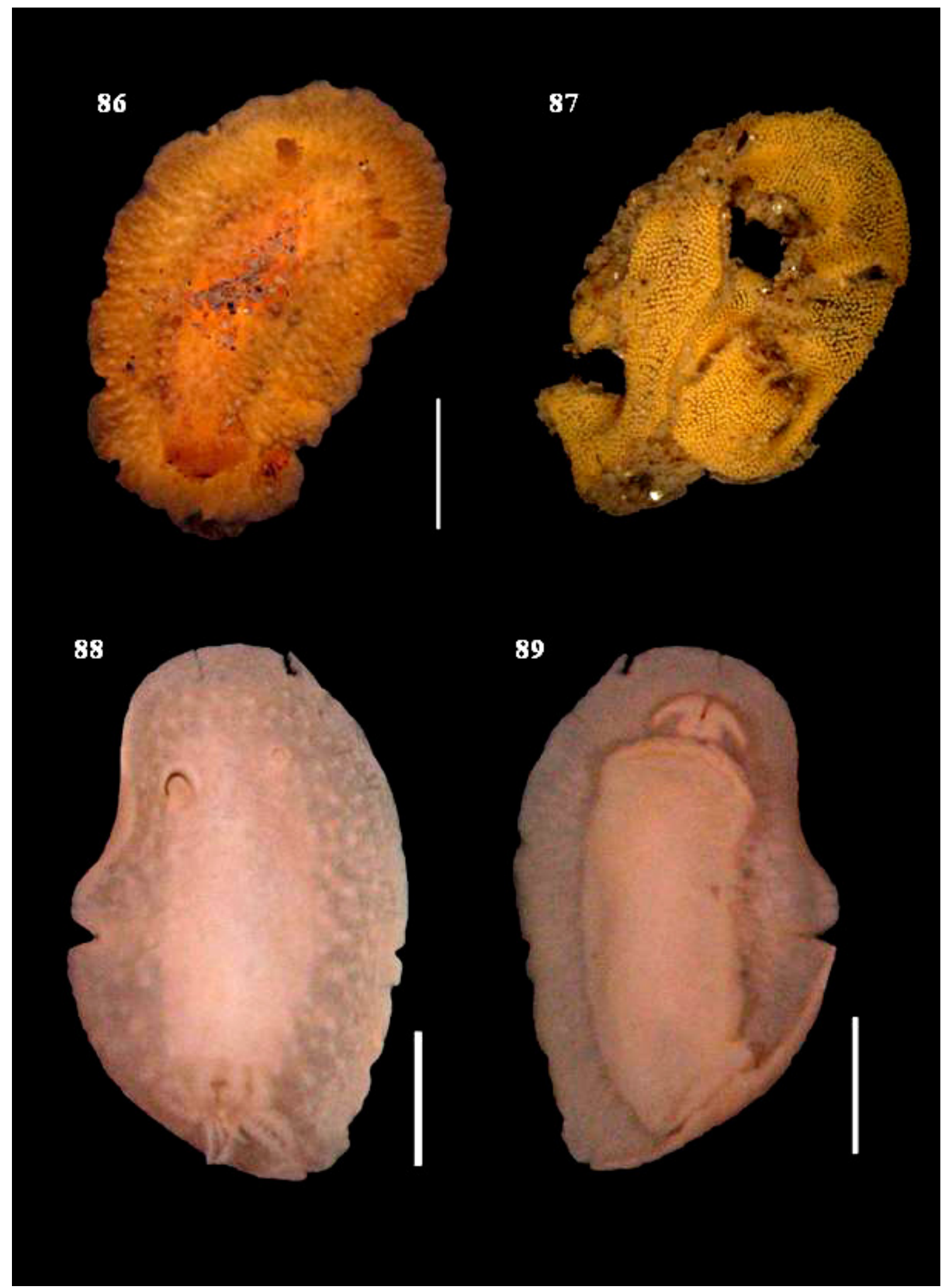

Figuras 86-89. Doris ilo. 86. Morfologia externa, vista dorsal, in vivo (MZSP 102801). Escala: 5 mm. 87. Postura. 88. Vista dorsal. 89. Vista ventral animal fixado (MZSP 25350). Escala: 2 mm. 
90

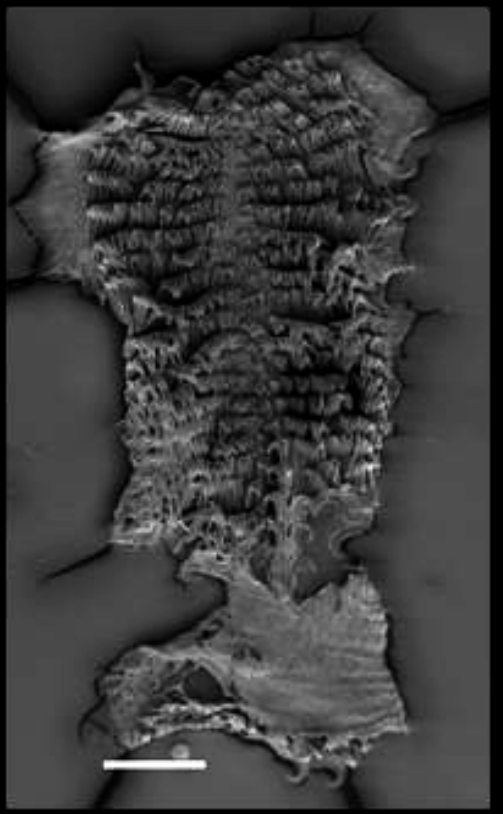

91

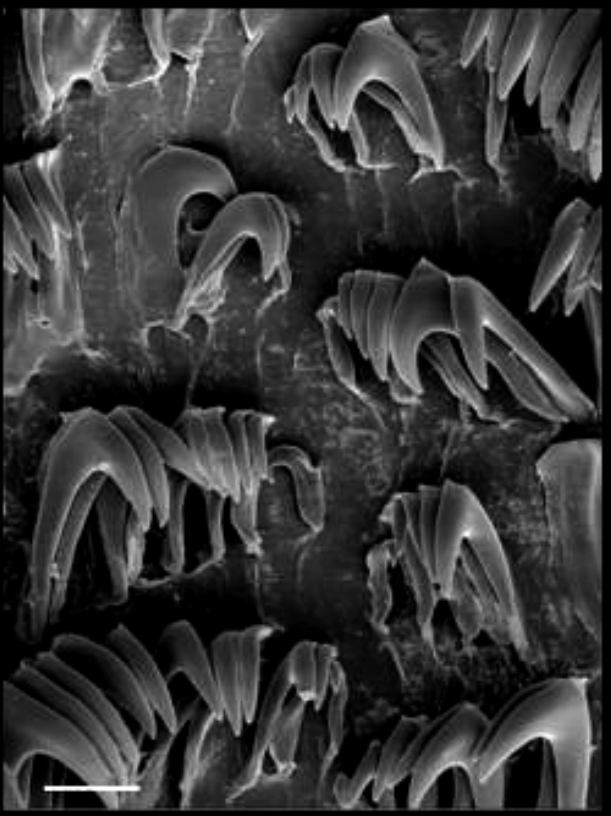

92

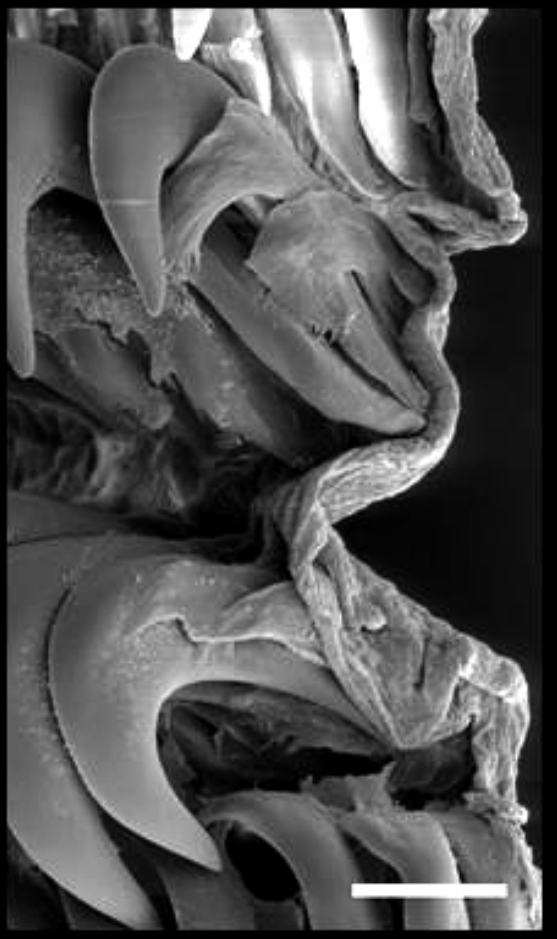

Figuras 90-92. Microscopia eletrônica da rádula de Doris ilo (MZSP 25349). 90. Vista panorâmica da rádula. Escala: $200 \mu \mathrm{m}$. 91. Vista central dos dentes laterais mais internos. 92. Vista dos dentes laterais mais externos. Escalas: $20 \mu \mathrm{m}$. 

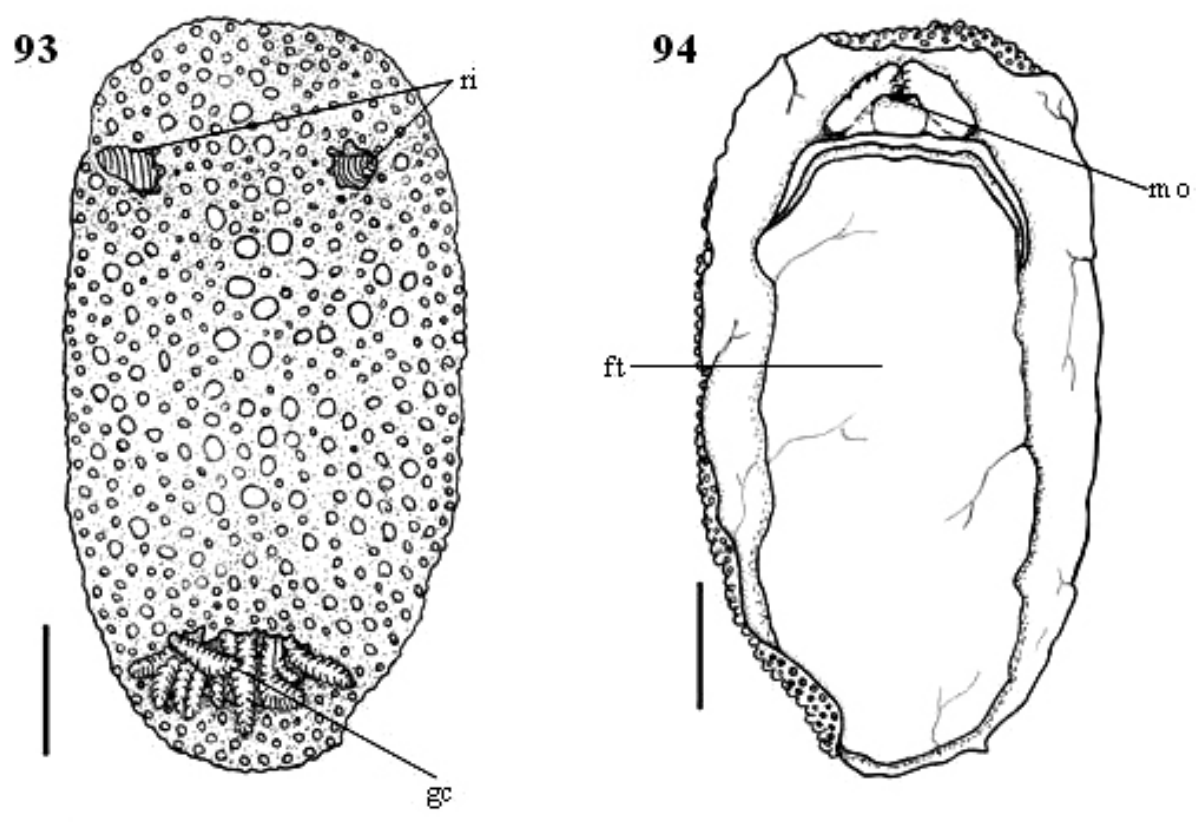

\section{5}

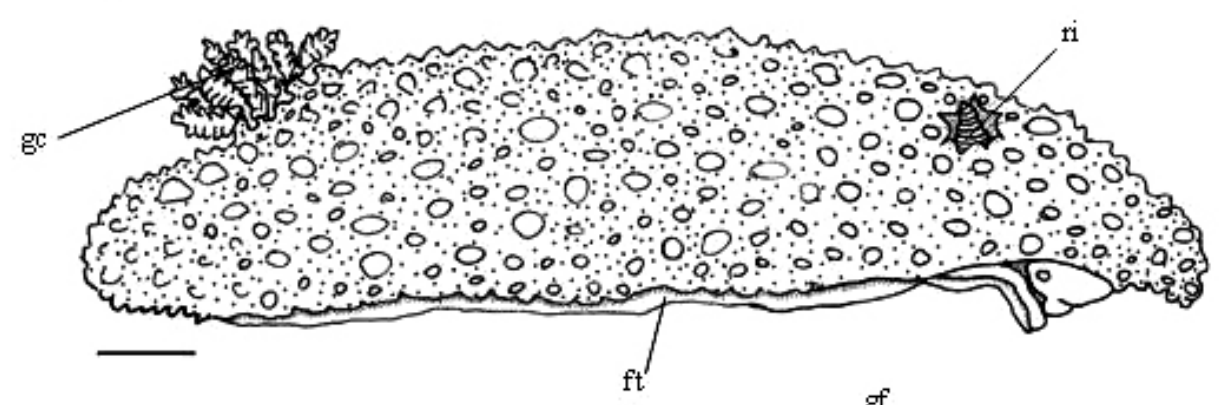

96

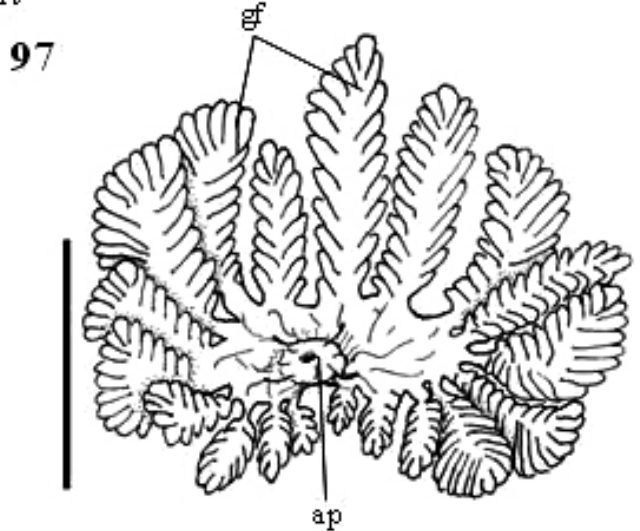

Figuras 93-97. Morfologia externa de Doris ilo. 93. Vista dorsal. 94. Vista ventral. 95. Vista lateral direita. 96. Vista dorsal, detalhe da cavidade do rinóforo. 97. Vista dorsal, círculo branquial com os filamentos menores na porção anterior. Escalas: $1 \mathrm{~mm}$. Abreviaturas - ap: papila anal; ft: pé; gc: círculo branquial; gf: filamento branquial; mo: boca; ri: rinóforo. 

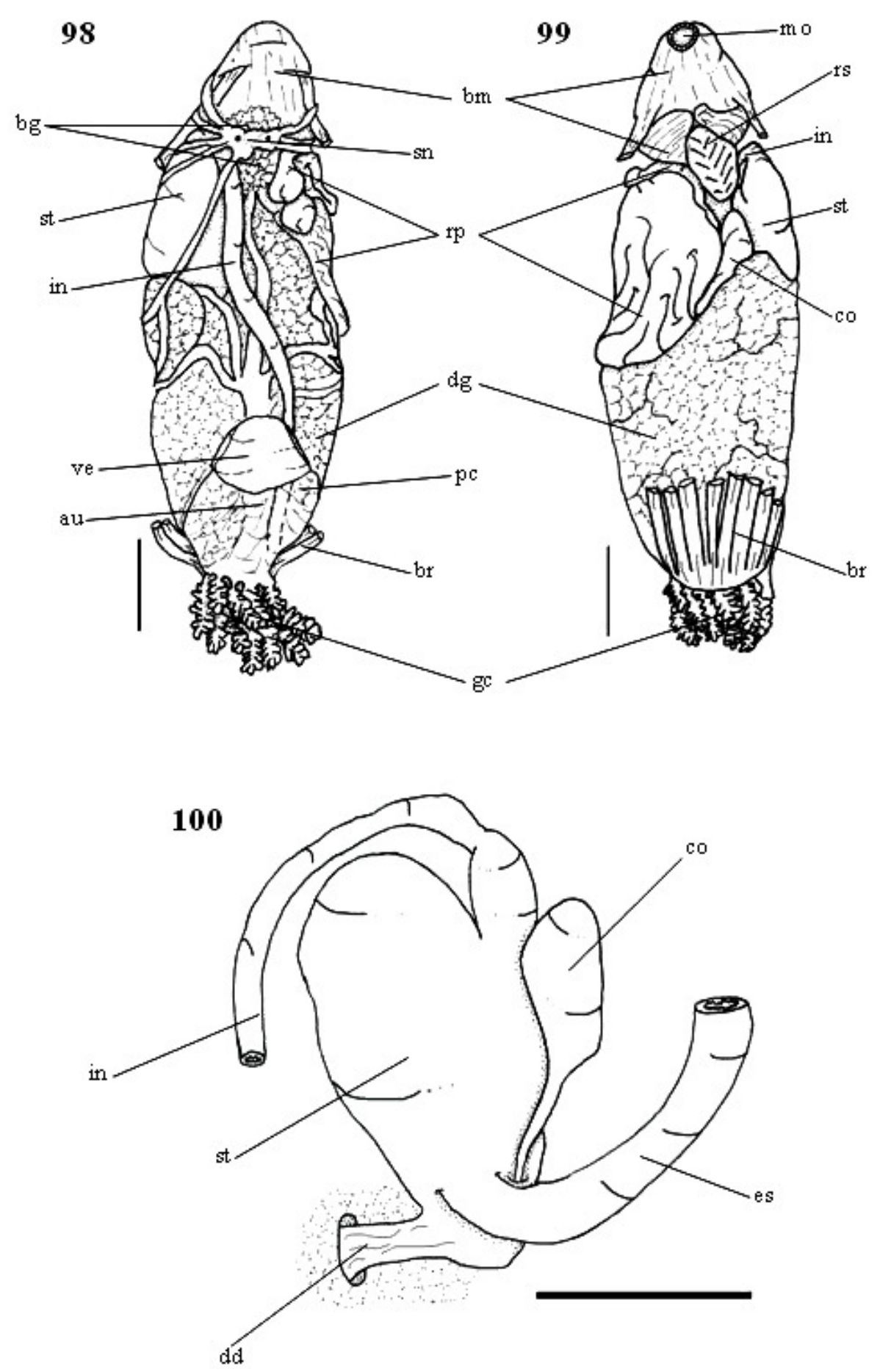

Figuras 98-99. Estruturas da hemocela de Doris ilo. 98. Vista dorsal. 99. Vista ventral. Escalas: $1 \mathrm{~mm}$. 100. Sistema digestivo médio, vista ventral. Escalas: $0,5 \mathrm{~mm}$. Abreviaturas: au: aurícula; bg: glândula de sangue; bm: massa bucal; br: músculo retrator da brânquia; co: ceco; dd: ducto da glândula digestiva; dg: glândula digestiva; es: esôfago; gc: círculo branquial; in: intestino; mo: boca; pc: pericárdio; rp: sistema reprodutor; sn: sistema nervoso; st: estômago; ve: ventrículo. 


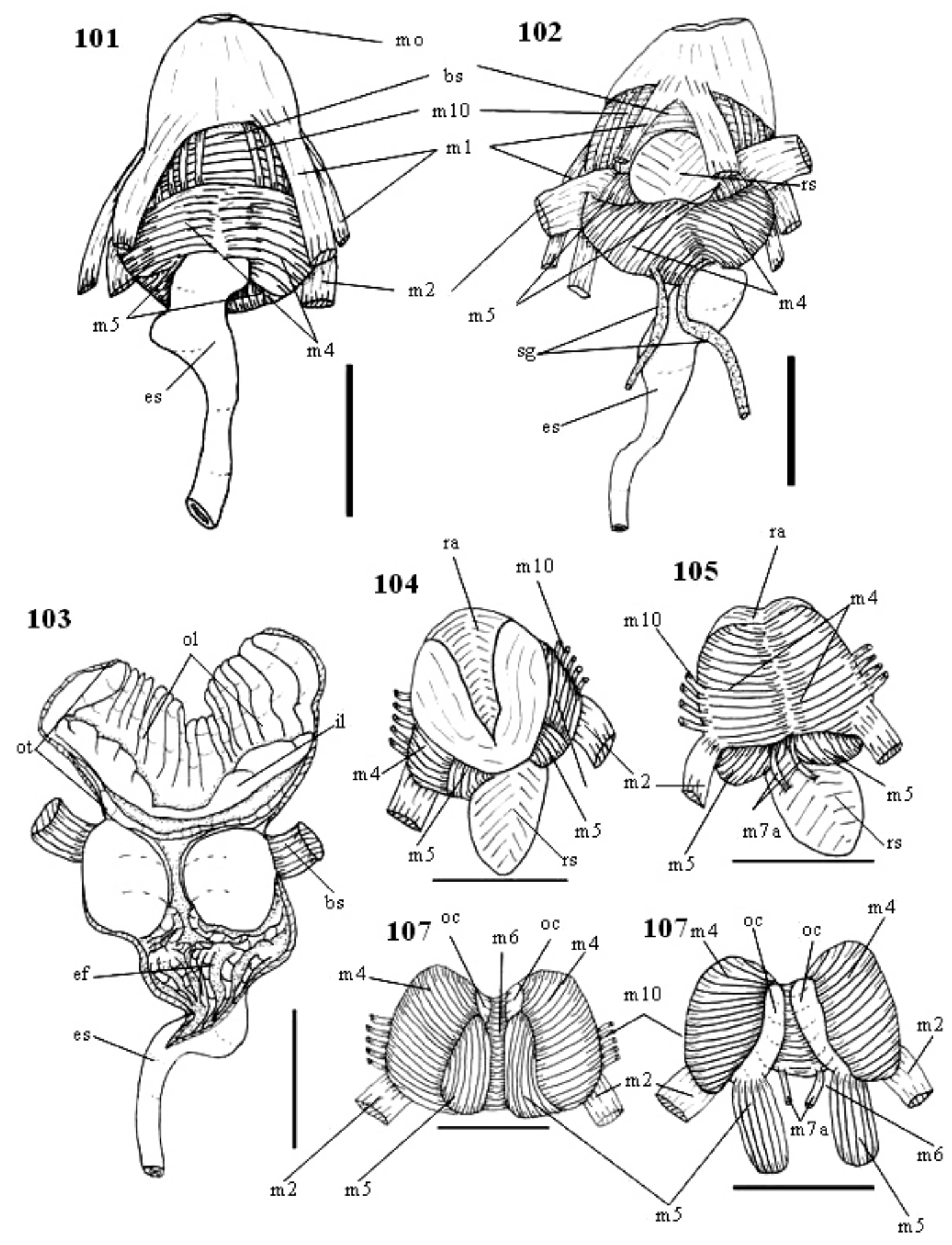

Figuras 101-103. Sistema digestivo anterior de Doris ilo. 101. Vista dorsal. 102. Vista ventral. 103. Vista ventral, corte longitudinal e odontóforo removido. 104-107. Odontóforo de Doris ilo. 104. Vista ventral. 105. Vista dorsal. 106. Vista ventral, rádula removida. 107. Vista ventral, $\mathrm{m} 4 \mathrm{e} \mathrm{m} 5$ rebatidos com exposição da cartilagem do odontóforo. Escalas: $1 \mathrm{~mm}$. Abreviaturas: bs: esfíncter bucal; ef: pregas esofágicas; es: esôfago; il: lábio interno; m1: músculos retratores da massa bucal; m2-m10: músculos do odontóforo; mo: boca; oc: cartilagem do odontóforo; ol: lábio externo; ot: tubo oral; ra: rádula; RS: saco radular. 

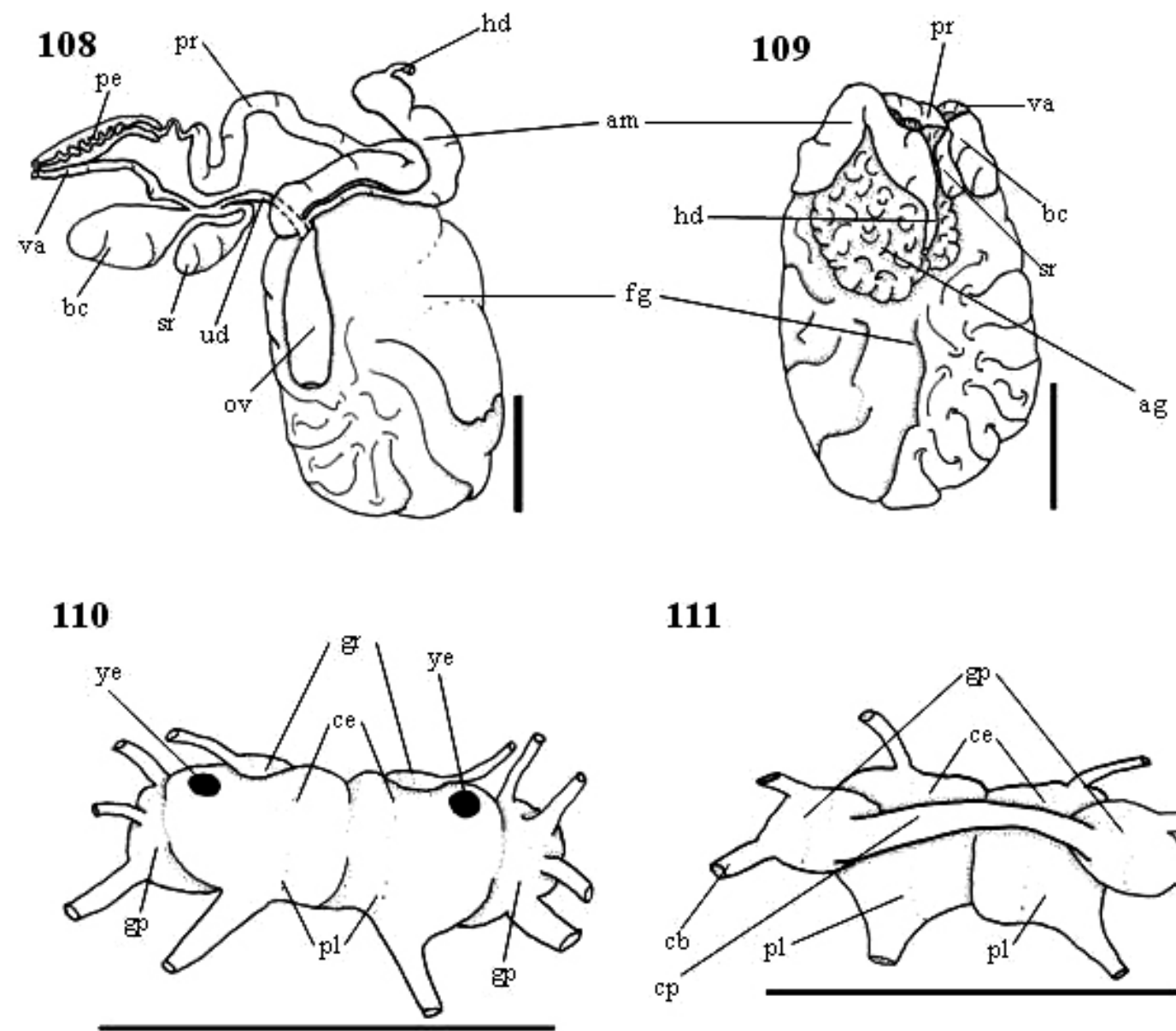

111

\section{2}

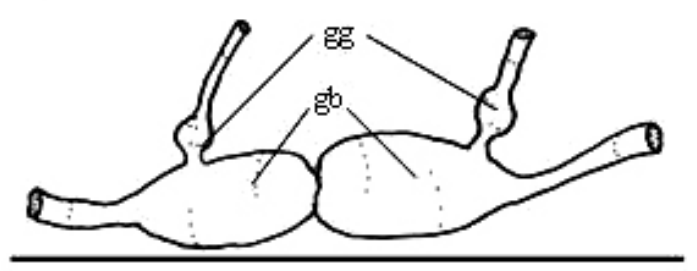

Figuras 108-109. Sistema reprodutor de Doris ilo. 108. Vista dorsal. 109. Vista ventral. 110-112. Sistema nervoso de Doris ilo. 110. Vista dorsal. 111. Vista ventral. 112. Detalhe do gânglio bucal e gastroesofágico, vista ventral; Escalas: $1 \mathrm{~mm}$. Abreviaturas - ag: glândula de albúmen; am: ampola; bc: bursa copulatrix; cb: comissura bucal; ce: gânglio cerebral; cg: conectivo do gânglio bucal; cp: comissura pediosa; fg: glândula feminina; gb: gânglio bucal; gg: gânglio gastro-esofágico; gp: gânglio pedioso; gr: gânglio rinoforal; hd: ducto hermafrodita; pe: pênis; pl: gânglio pleural; pr: próstata; sr: receptáculo seminal; va: vagina. 
(Figs. 113-138)

Siraius kyolis Marcus \& Marcus, 1967, p.64-66, figs. 80-84; Marcus, 1977: 10; Valdés et. al. 2006: 170-171

Doris kyolis: Valdés 2002: 540

Material tipo: Sintipos USNM 576280, não examinado.

Localidade-tipo. MacArthur Causeway, Biscayne Bay, Florida.

Material examinado - BAHAMAS. Ilhas Abaco, Treasure Cay, UF 449186, 01 ex. (C. Redferm col., 23/VI/1992), UF 449187, 01 ex. (C. Redferm col., 23/VI/1992); EUA, Flórida, Miami, MZSP 37979, 22 ex. secos (1971). TRINIDAD \& TOBAGO, Trinidad, MZSP 76040, 01 ex. (1962). BRASIL. Rio Grande do Norte, Nilza Floresta MZSP 96905, 01 ex. (V. Padula col., 13/iii/2009); Rio de Janeiro, Cabo Frio, Ilha do Japonês, MZSP 96909, 01 ex. (V. Padula col., 14/x/2006), Canal de Itajuru, MZSP 105145, 01 ex. (J. Alvim col., 10/iii/2012).

\section{Redescrição}

Morfologia externa (Figs. 113-115; 119-123): Tamanho variando entre 12-14 mm de comprimento. Coloração do animal amarelo escuro com pontos pretos ou esverdeados, com tubérculos que cobrem o noto de cor escura. Corpo bojudo e rígido (exemplar fixado). Tubérculos de diferentes tamanhos, na região dorsal, seguindo para a lateral os tubérculos são menores. Rinóforos com 15 lamelas com a borda das cavidades lobada. Brânquia com 15 a 18 filamentos branquiais e borda da cavidade branquial 
circular também com um aspecto lobado. Tentáculos orais em forma de barril com um sulco no lado externo (como em $D$. bovena e $D$. ilo). Borda anterior do pé sulcada.

Hemocela (Figs. 124-125): A topográfica geral do animal semelhante à das espécies anteriores. Pericárdio no $1 / 3$ posterior dorsal. Sistema nervoso dorsal ao aparato bucal com glândula de sangue dividida como em $D$. bovena e $D$. ilo. Glândula digestiva ventral à gônada. Círculo branquial posterior dorsal.

Sistema circulatório e excretor (Fig. 123-124): segue o mesmo padrão das outras três espécies descritas. Músculo retrator da brânquia presente. Ventrículo mais alongado do que piriforme. Filamentos branquiais mais finos do que em D. bovena, porém mais espaçados do que em $D$. verrucosa e $D$. januarii, os filamentos posteriores são menores do que os anteriores, de uma forma decrescente, mas completam o círculo branquial, diferente de $D$. ilo, que não fecha o círculo.

Sistema digestivo (Figs. 126-133): aparato bucal anterior ocupando $10 \%$ da massa visceral. Tubo oral com lábio superior com pregas longitudinais grossas e lábio inferior com duas pregas horizontais. Odontóforo mantém o padrão das espécies anteriores, com as seguintes diferenças: m2) apresenta as mesmas proporções de largura e espessura de $D$. januarii, $D$. bovena e $D$. ilo, no entanto no $1 / 3$ anterior o $\mathrm{m} 2$ se expande, como um leque; m5) segue até aproximadamente a metade da cartilagem do odontóforo, é cerca de $1 \frac{1}{2}$ da largura e aproximadamente o mesmo tamanho do m4; m6) segue com o mesmo formato para $D$. verrucosa e $D$. januarii, tendo sua porção posterior quatro vezes mais larga que a anterior. Dentes radulares (Figs. 116-119): fórmula radular apresentando 37 fileiras com 1.35.0.35.1 dentes, com o dente lateral mais externo cuspidado, de um exemplar com $12 \mathrm{~mm}$ de comprimento, e fórmula radular 40 fileiras com 2.40.0.40.2 dentes, com dois dentes laterais mais externos cuspidados. Esôfago com a parte anterior duas vezes mais larga do que em $D$. 
verrucosa, parte posterior do esôfago, quando se conecta com o estômago, é mais fina, cerca de $1 / 2$ da largura da anterior. Par de glândulas salivar tubular, esquerda mais longa, de duas a três vezes o comprimento da direita. Estômago com pregas irregulares concentradas na região central. Intestino segue o padrão das espécies já descritas. Ceco com cerca de $1 / 3$ da largura e $2 / 3$ do comprimento do estômago. Glândula digestiva com aspecto esponjoso e coloração amarronzada ocupa cerca de $20 \%$ da massa visceral.

Sistema reprodutor (Figs. 134-135): ocupa 20\% das estruturas da hemocela. Segue o mesmo padrão das espécies anteriores, com as seguintes diferenças: Ampola com o mesmo tamanho e largura da próstata. Próstata alongada, tubular e com diâmetro contínuo em toda sua extensão. Ducto deferente ausente. Músculo do pênis ausentes, como em D. bovena e $D$. ilo. Pênis com metade do tamanho da vagina. Gônada localizada dorsal à glândula digestiva de fácil distinção, coloração bege clara, ocupa cerca de $40 \%$ da massa visceral. Glândula feminina bem desenvolvida, arredondada, irregular, ocupa $80 \%$ do sistema reprodutor, porém ocupa uma área ventral, sobre a glândula digestiva, maior do que em $D$. januarii. Glândula mucosa ocupa 2/3 e apresenta uma coloração bege, glândula de albúmen ocupa cerca de $1 / 3$ da região mais anterior, dilatado com formato irregular e com uma coloração bege escuro. Oviduto com cerca de 1/8 do tamanho da glândula feminina. Ducto uterino longo como em $D$. bovena e $D$. ilo, cerca de duas vezes o comprimento do visto em $D$. verrucosa e $D$. januarii. Receptáculo seminal com formato piriforme, cerca de $2 / 3$ do tamanho da bursa copulatrix e $1 / 2$ da largura. Bursa copulatrix com formato arredondado. Vagina tubular, cerca de duas vezes mais comprida e com aproximadamente metade do diâmetro do pênis.

Sistema nervoso (Figs. 124; 136-138): ocupa aproximadamente 1/23 da hemocela, com características semelhantes às espécies anteriores, com algumas 
diferenças: glândula de sangue cobrindo parcialmente o sistema nervoso, como em $D$. bovena. Comissura pediosa simples e curta, mas duas vezes maior que a de $D$. bovena. Gânglios rinoforais com formato de bulbo, como nas espécies anteriores, porém mais sutil e mais próximo um do outro. Comissura que conecta os dois gânglios bucais é mais alongada, como em D. verrucosa. Conectivo entre os gânglios bucais e gastroesofágicos sai do centro do gânglio bucal e não das bordas, como nas espécies já descritas. Gânglios-gastroesofágicos mais distantes dos bucais e aproximadamente 1/3 do tamanho do gânglio bucal. Olhos dorsais, situados nos gânglios cerebrais. Estatocistos localizados interiormente aos gânglios pediosos, pequenos e iridescentes.

Distribuição: Leste da Flórida a Cabo Frio/RJ (no presente trabalho). Registros confirmados: Leste da Flórida (EUA); Curaçao (Ilhas ABC); Venezuela; Bahamas, Porto Rico, Ilhas Virgens; St. Lucia; Grenadines (St. Vicent e Grenadines); Barbados; Nilza Floresta/ RN, Fernando de Noronha, PE, Búzios, RJ e Cabo Frio/RJ (Brasil).

Habitat: vive sob rochas na região infralitoral. 


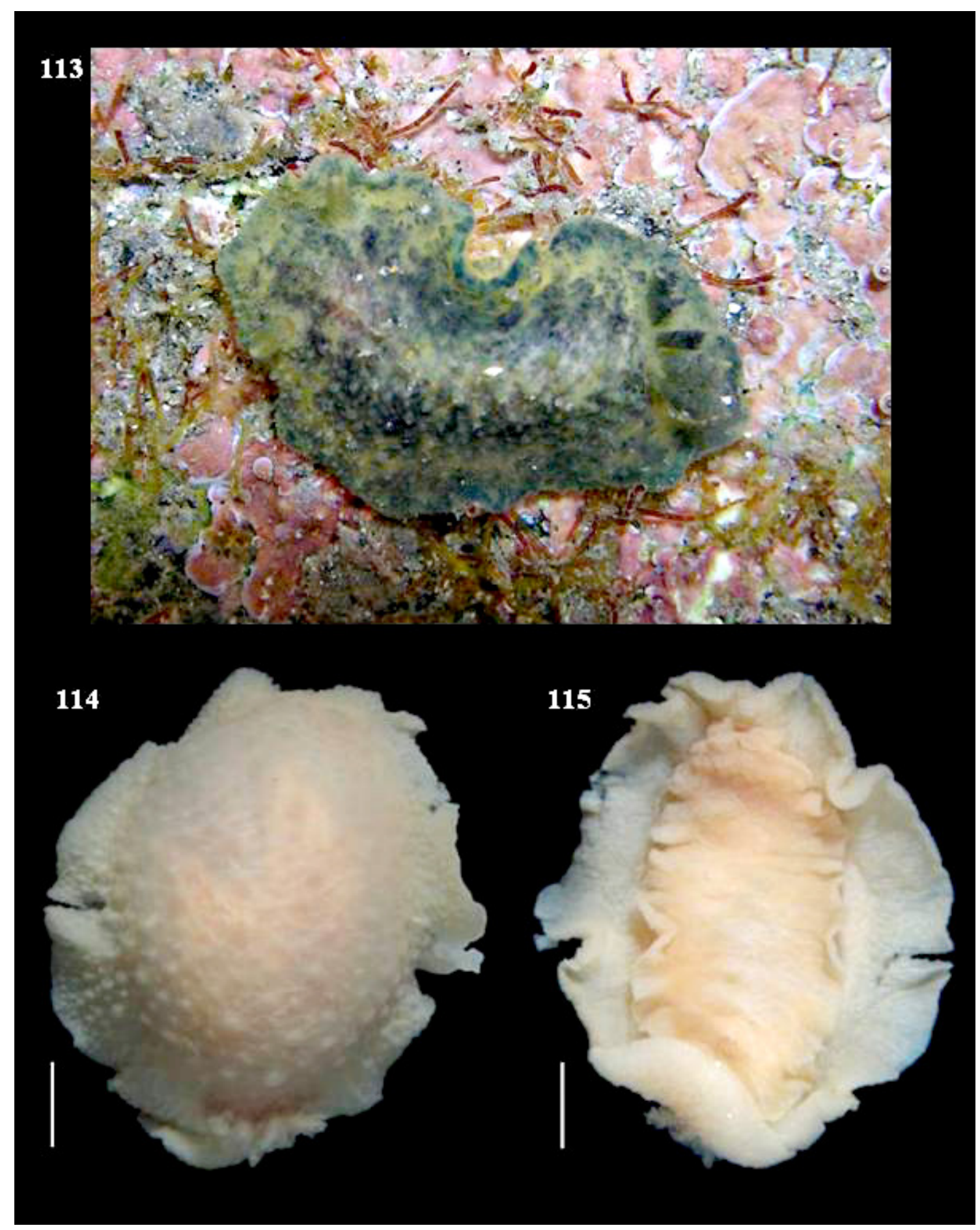

Figuras 113-115. Doris kyolis. 113. . Morfologia externa, vista dorsal, in vivo (MZSP 96910). 114. Vista dorsal animal fixado. 115. Vista ventral animal fixado (UF 440187). Escala: $2 \mathrm{~mm}$. 


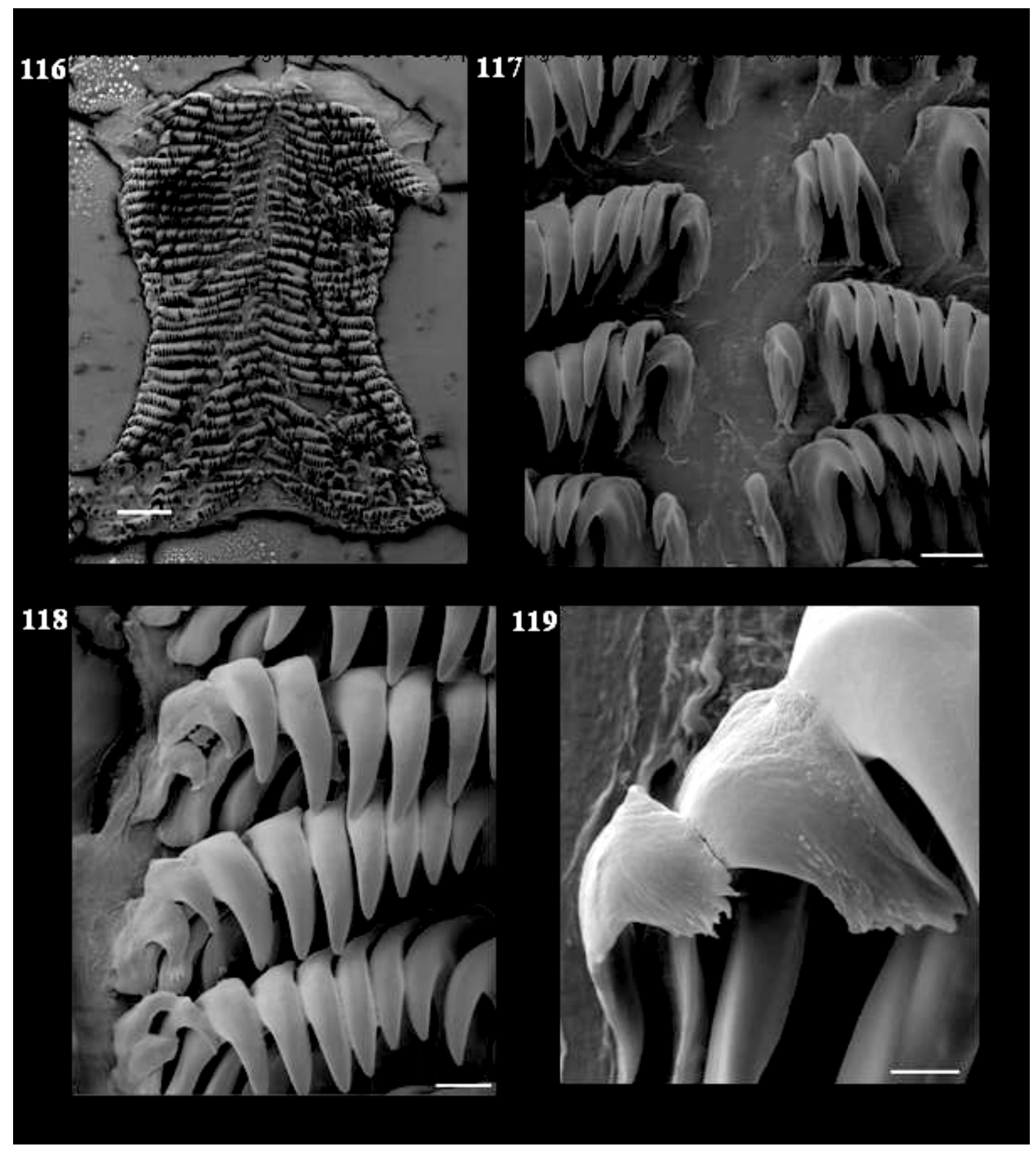

Figuras 116-119. Microscopia eletrônica da rádula. Doris kyolis. 116-118. (UF 440187). 116. Vista panorâmica da rádula. Escala: $200 \mu \mathrm{m}$. 117. Vista central dos dentes laterais mais internos. 118. Vista dos dentes laterais mais externos. Escalas: $20 \mu \mathrm{m} .119$. Detalhe dos dois dentes laterais mais externos (MZSP 76040). Escala: $5 \mu \mathrm{m}$. 

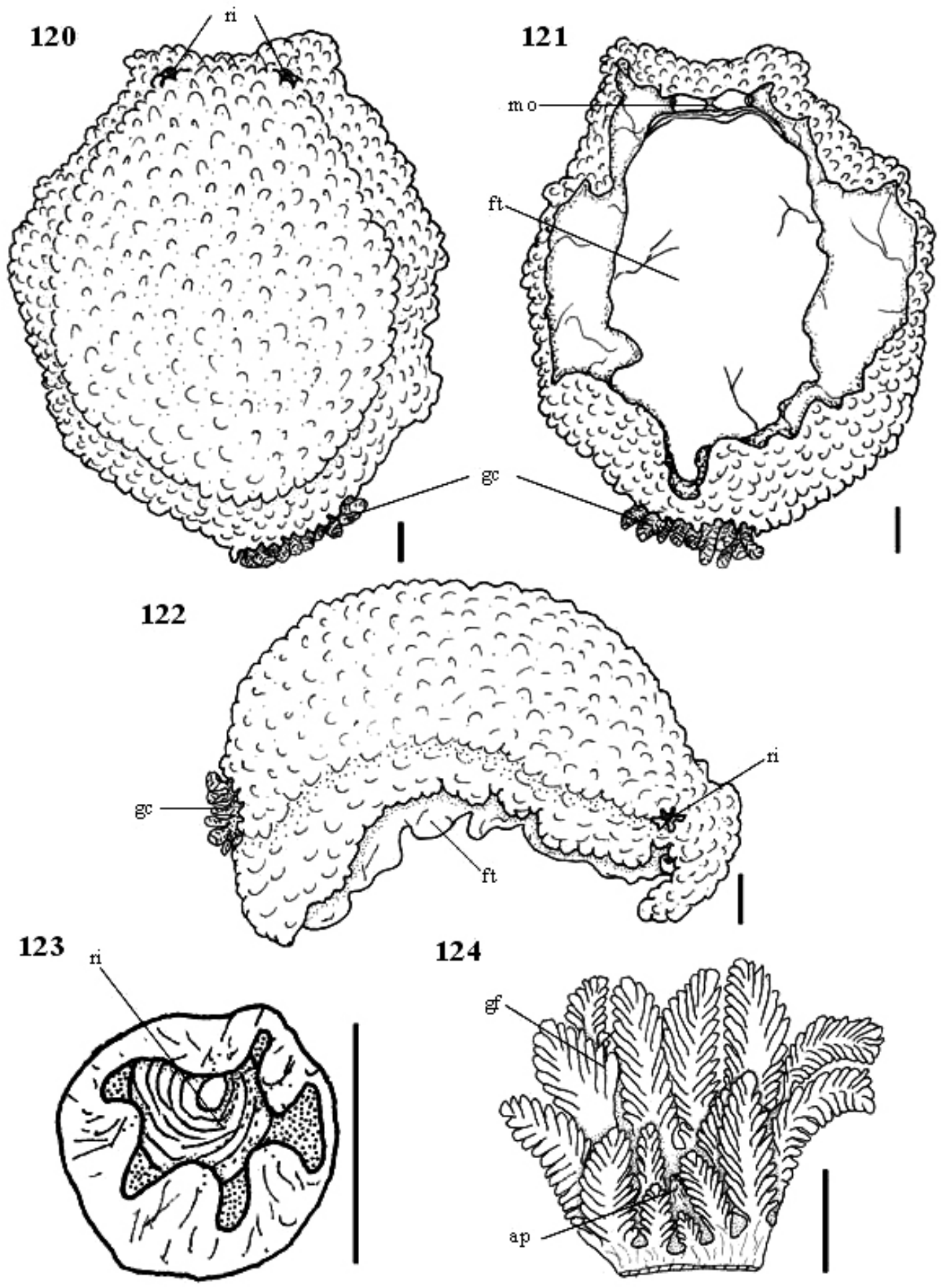

Figuras 120-124. Morfologia externa de Doris kyolis. 120. Vista dorsal. 121. Vista ventral. 122. Vista lateral. 123. Detalhe da cavidade do rinóforo, vista dorsal. 124. Círculo branquial, vista dorsal, com os filamentos menores na porção anterior. Escalas: $1 \mathrm{~mm}$. Abreviaturas - ap: papila anal; ft: pé; gc: círculo branquial; gf: filamento branquial; mo: boca; ri: rinóforo. 

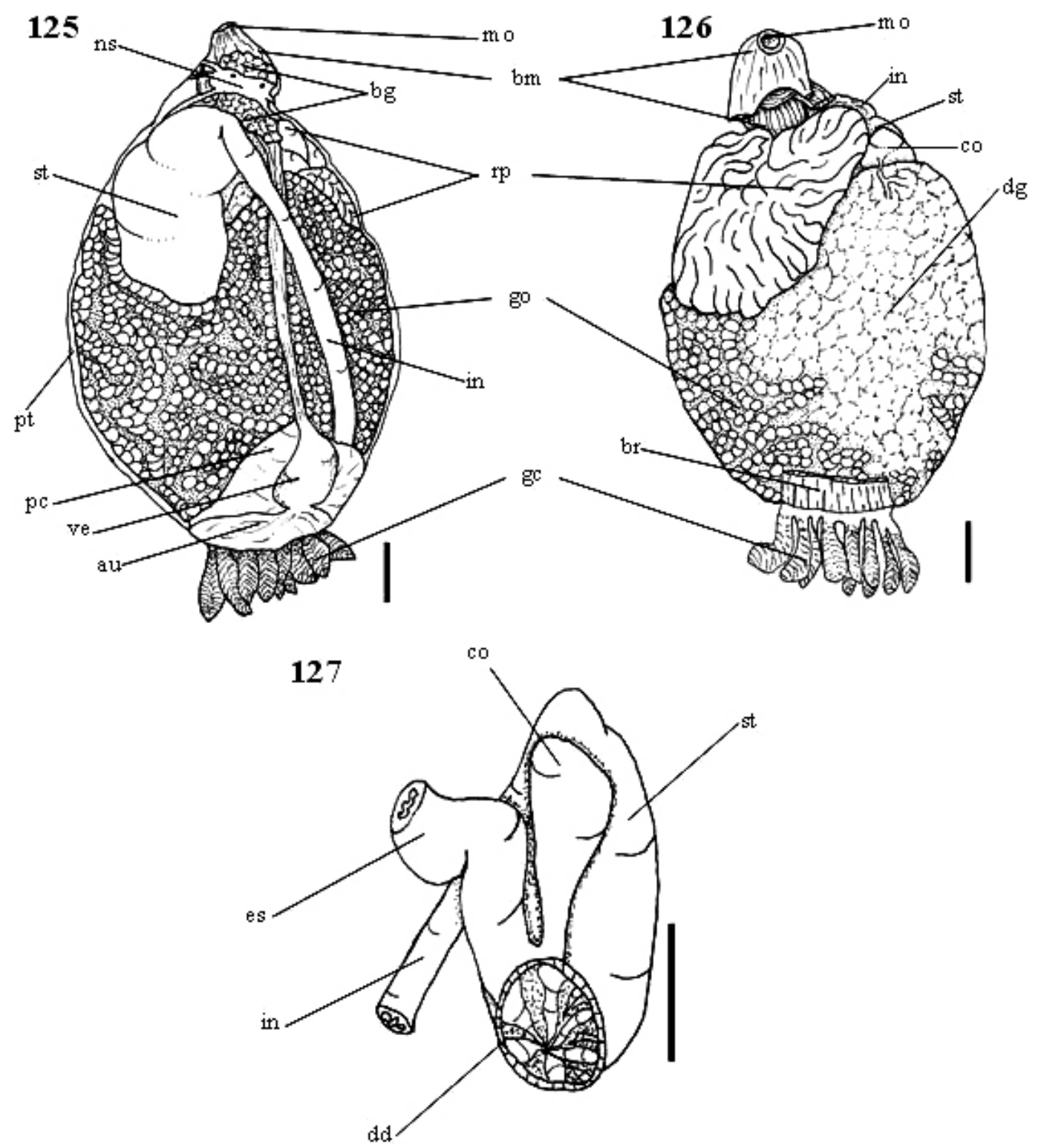

Figuras 125-126. Estruturas da hemocela de Doris kyolis. 125. Vista dorsal. 126. Vista ventral. 127. Sistema digestivo médio, vista ventral. Escalas: $1 \mathrm{~mm}$. Abreviaturas - au: aurícula; bc: bursa copulatrix; bg: glândula de sangue; bm: massa bucal; br: músculo retrator da brânquia; co: ceco; dg: glândula digestiva; do: abertura digestiva: es: esôfago; gc: círculo branquial; go: gônada; in: intestino; mo: boca; ns: sistema nervoso; pt: pertitônio; rp: sistema reprodutor; st; estômago; ve: ventrículo. 

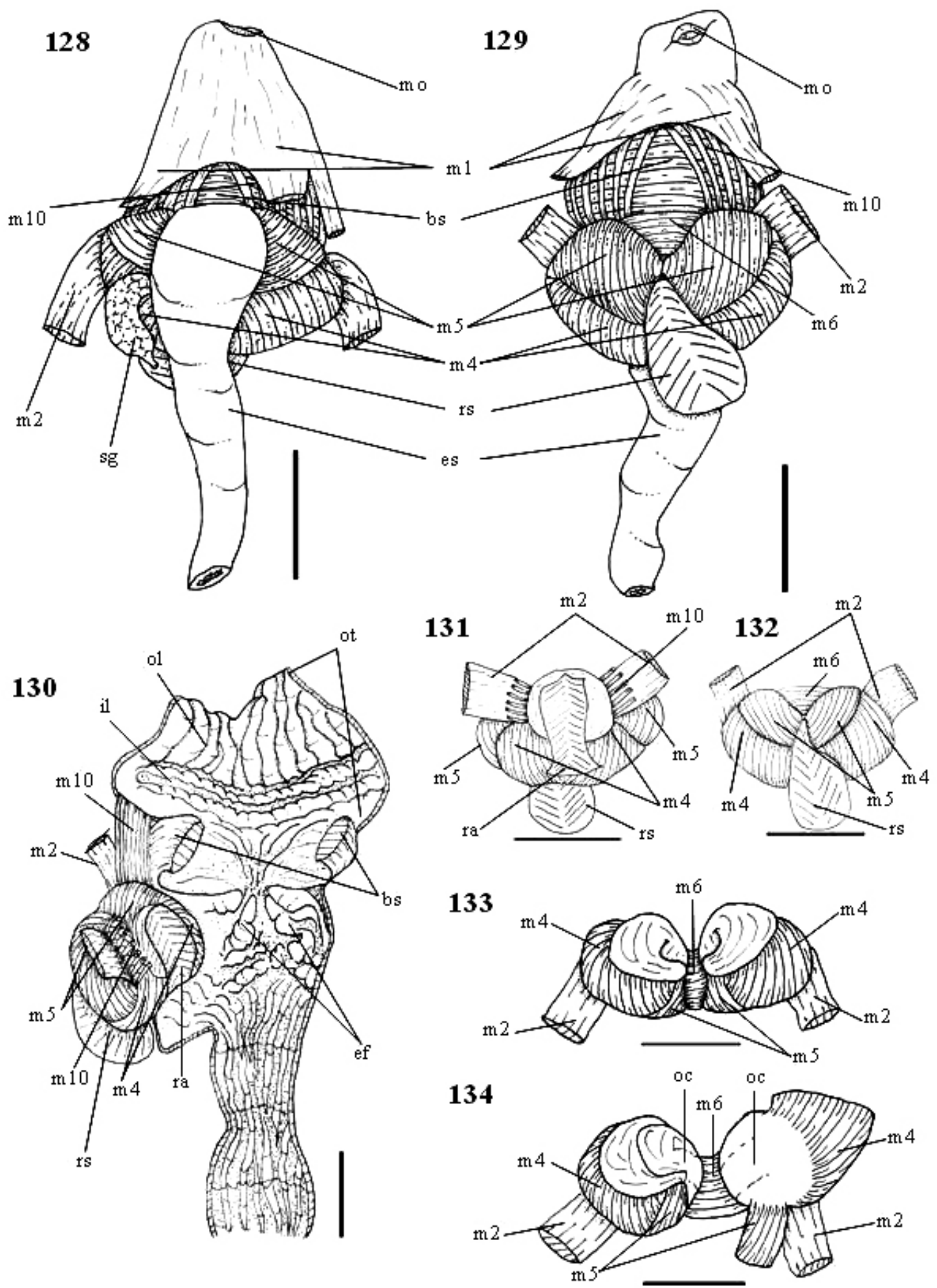

Figuras 128-130. Sistema digestivo médio de Doris ilo. 128. Vista dorsal. 129. Vista ventral. 130. Corte longitudinal, vista ventral, odontóforo removido. 131-134. Odontóforo de Doris kyolis. 131. Vista ventral. 132. Vista dorsal. 133. Vista ventral, rádula removida. 134. Vista ventral, $\mathrm{m} 4 \mathrm{e} \mathrm{m} 5$ rebatidos com exposição da cartilagem do odontóforo. Escalas: $1 \mathrm{~mm}$. Abreviaturas: bs: esfíncter bucal; ef: pregas essofágicas; es: esôfago; il: lábio interno; m1: músculos retratores da massa bucal; m2-m10: músculos do odontóforo; mo: boca; oc: cartilagem do odontóforo; ol: lábio externo; ot: tubo oral; ra: rádula; RS: saco radular. 

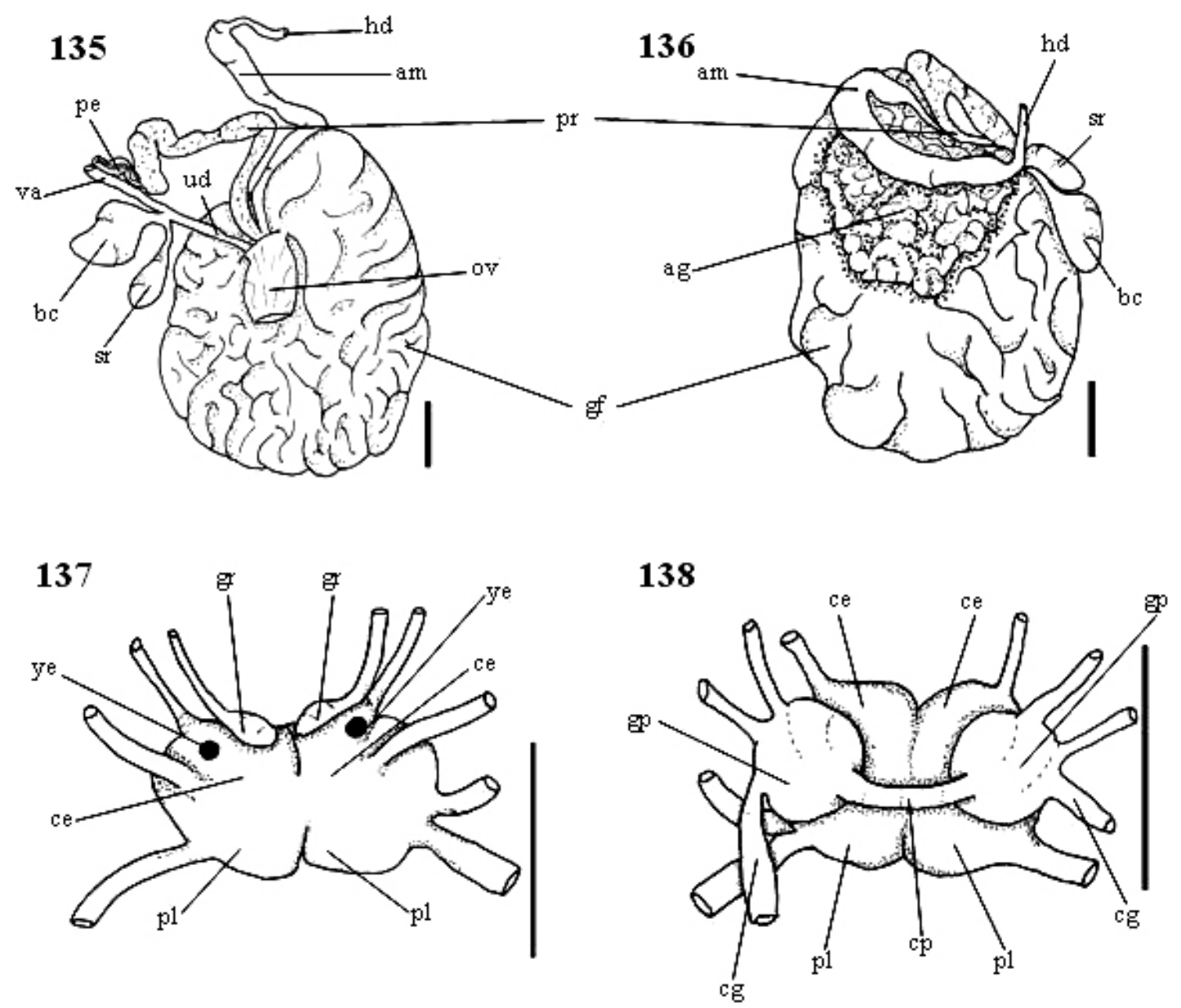

139

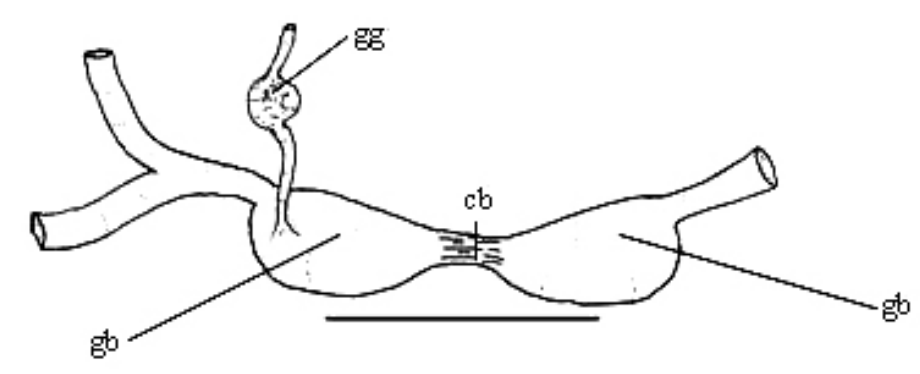

Figuras 135-136. Sistema reprodutor de Doris kyolis. 135. Vista dorsal. 136. Vista ventral do sistema reprodutor. 137-139. Sistema nervoso de Doris kyolis. 137. Vista dorsal. 138. Vista ventral. Escalas: 1 $\mathrm{mm}$. 139. Detalhe do gânglio bucal e gastro-esofágico, vista ventral. Escala: $0,5 \mathrm{~mm}$. Abreviaturas - ag: glândula de albúmen; am: ampola; bc: bursa copulatrix; cb: comissura bucal; ce: gânglio cerebral; cg: conectivo do gânglio bucal; cp: comissura pediosa; fg: glândula feminina; gb: gânglio bucal; gg: gânglio gastro-esofágico; gp: gânglio pedioso; gr: gânglio rinoforal; hd: ducto hermafrodita; pe: pênis; pl: gânglio pleural; pr: próstata; sr: receptáculo seminal; ud: ducto uterino; va: vagina. 


\section{DISCUSSÃO}

As quatro espécies aqui estudadas apresentaram as características típicas para Doridoidea, já citadas anteriormente (Odhner, 1934; Valdés \& Gosliner, 1999; Wägele \& Willan, 2000; Valdés, 2002; Pola et. al., 2007; Pola \& Gosliner, 2010). Também foram confirmadas as características consideradas para o táxon Cryptobranchia (Valdés, 2002).

Para ambas as espécies, Doris verrucosa e Doris januarii, as características externas específicas, como a presença de dois tubérculos alongados ao redor da cavidade do rinóforo e os oito tubérculos alongados ao redor do círculo branquial, foram confirmadas, como citadas em trabalhos de revisão, anatômicos e filogenéticos (Marcus, 1955; Schmekel, 1968; Valdés, 2000, 2002) (Figs. 11, 12). Já Doris bovena apresentou as cavidade do rinóforo e do círculo branquial rodeadas por papilas mais suaves, e não por tubérculos bem definidos, característica esta visualizada apenas para essa espécie (Fig. 69). Para Doris ilo e Doris kyolis as cavidades do rinóforo apresentaram-se lobadas, sendo que em $D$. ilo não mantiveram um número fixo de lobos, enquanto que em D. kyolis, a cavidade do rinóforo apresentou entre 4 e 5 lobos em todos os exemplares analisados (Figs. 96, 123).

Para todas as espécies estudadas, o rinóforo mostrou-se igual no formato e topologia, porém variando no número de lamelas. Para os exemplares de D. verrucosa foram observadas aproximadamente 13 lamelas do rinóforo, já os exemplares de $D$. januarii apresentaram cerca de 9 lamelas. Em D. bovena, os exemplares apresentaram cerca de 10 lamelas. Já em $D$. ilo e $D$. kyolis esse número se sobrepôs, sendo 15 lamelas para ambas as espécies.

Os tubérculos que cobrem o dorso das espécies também apresentaram diferenças significativas, em $D$. verrucosa os tubérculos são mais alongados e distantes uns dos 
outros (Figs. 8, 10), enquanto que em $D$. januarii os tubérculos são mais arredondados e próximos uns dos outros (Figs. 40, 42). Em D. bovena os tubérculos são mais sutis e menores, dando um aspecto macio para o animal (Figs. 66, 68). D.ilo e D. kyolis apresentaram o dorso coberto por pequenos tubérculos, no entanto mais definidos do que em D. bovena (Figs. 93, 95, 120 e 122).

O círculo branquial apresentou-se diferente entre as espécies variando no número de filamentos e espessura das lamelas, no entanto todas apresentaram os filamentos simples e unipinados. D. verrucosa e $D$. januarii apresentaram 16 filamentos branquiais, com as lamelas bem próximas umas das outras e um círculo branquial completo (Fig. 12). D. bovena apresentou 10 filamentos, com lamelas mais grossas, cerca de duas vezes a espessura das lamelas de D. verrucosa e D. januarii (Fig. 70). D. ilo foi a que apresentou a brânquia mais distinta entre as espécies, sendo 22 filamentos, e formato exclusivo do circulo branquial, tendo os filamentos posteriores seguindo para o centro do círculo, como descrito por Marcus (1955) (Fig. 97). Para os exemplares de D. kyolis o número de filamentos variou entre 15 e 18, também com lamelas próximas como em D. verrucosa, D. januarii e D. ilo, diferente da descrição original (Marcus \& Marcus, 1967) que relata 11 filamentos branquiais (Fig. 124).

Todas as espécies seguiram o mesmo padrão anatômico, com a boca localizada ventral e entre os prolongamentos laterais, que não são tentáculos. Essa distinção entre prolongamentos e tentáculos diferencia Dorididae de Discodorididae, está última apresentando tentáculos orais digitiformes (Valdés, 2002; Dayrat and Gosliner, 2005; Dayrat, 2010).

D. verrucosa e D. januarii apresentaram prolongamentos laterais com formato triangular e com sulco ventral (Figs. 9, 41). Já D. bovena, D. ilo e D. kyolis apresentaram os prolongamentos laterais em formato de "barril" com um sulco lateral, 
como relatado nas respectivas descrições originais (Marcus, 1955; Marcus \& Marcus, 1967) (Figs. 67, 94, 121).

O pé também se mostrou similar em todas as espécies, com a porção anterior sulcada horizontalmente e não fendida longitudinalmente na região mediana, como em Discodorididae. D. verrucosa apresentou o pé largo, mas não do mesmo tamanho da borda do noto e com a mesma proporção de largura na parte anterior e posterior, diferentemente de $D$. januarii que apresentou o pé cerca de duas a três vezes mais amplo do que $D$. verrucosa, deixando uma pequena faixa do noto visível, e mantendo as proporções de largura das partes anterior e posterior, como em D. verrucosa (Figs. 9, 41). D. bovena exibiu um pé largo como em $D$. verrucosa, mas com a porção posterior mais afunilada que a anterior (Fig. 67). D. ilo, manteve as proporções de largura do pé como em D. verrucosa, porém com a parte posterior mais próxima a borda do noto (Fig. 94) e em D. kyolis o pé manteve-se semelhante às proporções encontradas em $D$. verrucosa (Fig.121).

As estruturas da hemocela mostraram-se semelhantes em topologia, no entanto diferem-se proporcionalmente no tamanho, para cada espécie. A diferença de tamanho das estruturas foi mais acentuada na glândula digestiva. Para D. verrucosa, D. januarii, D. bovena e D. ilo a glândula digestiva ocupa cerca $50 \%$ e $60 \%$ da hemocela, enquanto que em D. kyolis ocupa cerca de $20 \%$ da hemocela (Figs. 125, 126).

Todas as espécies descritas neste trabalho apresentaram características semelhantes para o sistema circulatório e mantiveram um padrão de brânquias com filamentos simples e unipinados. No sistema excretor também apresentaram similaridades entre as estruturas, como vesícula e câmara renal e o nefróstoma que se mostrou apenas como um pequeno orifício na base da papila anal, semelhante em todas as espécies. 
Foi possível inferir importantes diferenças anatômicas no sistema digestivo anterior, entre as espécies analisadas, com ênfase nos músculos do odontóforo. $D$. verrucosa apresentou o $\mathrm{m} 2$ bem curto e espesso, enquanto que $D$. januarii apresentou esse mesmo músculo cerca de quatro vezes mais alongado e delgado do que em $D$. verrucosa. D. bovena, $D$. ilo e $D$. kyolis mantiveram o padrão de $D$. januarii em largura e espessura, mas para $D$. ilo o $\mathrm{m} 2$ se mostrou cerca de $1 / 4$ mais longo e em D. kyolis a partir do $1 / 3$ anterior o $\mathrm{m} 2$ se expande, como um leque. $\mathrm{O} \mathrm{m} 5$ se mostrou praticamente semelhante em todas as espécies, em $D$. verrucosa o m5 cobre a metade posterior interna da cartilagem do odontóforo, assim como para D. bovena e D. kyolis (Fig. 27, 80 e 134). Já para D. januarii o m5 cobre cerca de $1 / 3$ da cartilagem do odontóforo (Fig. 53) e para $D$. ilo o $\mathrm{m} 5$ cobre praticamente toda a face interna da cartilagem do odontóforo (Fig. 106). Outro músculo que apresentou variação foi o m6, em $D$. verrucosa o m6 mostrou-se espesso e com a região anterior três vezes menor do que a posterior, com um formato de "funil". Em D. januarii o m6 manteve o mesmo padrão do encontrado em $D$. verrucosa, porém com aproximadamente metade da espessura. $D$. bovena apresentou o m6 mais uniforme ao longo do seu comprimento e com a mesma espessura do visto em D. verrucosa. Em D. ilo e D. kyolis o m6, manteve o padrão anatômico descrito para $D$. verrucosa, porém com a região anterior duas vezes menor que a posterior e com a mesma espessura visualizada em $D$. januarii.

As rádulas de todas as espécies mantiveram um padrão, com dente raquidiano ausente, e os laterais com uma cúspide em forma de gancho. Porém para $D$. ilo os dois dentes laterais mais externos mostraram-se multicuspidados, diferenciando-se da descrição original (Marcus, 1955). D. kyolis também apresentou os dois dentes laterais mais externos multicuspidados, como em $D$. ilo, corroborando com a descrição de Marcus \& Marcus (1967). 
O par de glândulas salivares também se mostrou diferente entre as espécies. $D$. verrucosa apresentou um par de glândula tubular, longo e com os ductos das glândulas com uma parte externa, antes de se inserir na porção dorsal e anterior do esôfago. (Fig.21). Em D. januarii o par de glândulas manteve o mesmo padrão que D. verrucosa, mas não apresentou a parte externa do ducto das glândulas (Fig. 46). D. bovena manteve o padrão de comprimento e formato de $D$. verrucosa e $D$. januarii, mas com metade da largura (Fig. 75). Nos exemplares de D. ilo não foi possível localizar o par de glândulas salivares devido ao estado de conservação dos exemplares. D. kyolis apresentou o par de glândulas mais distinto das demais, com a glândula direita aproximadamente três vezes mais curta que a esquerda, como descrito por Marcus \& Marcus (1967).

No sistema digestivo médio, o esôfago manteve-se semelhante para todas as espécies, exceto para D. kyolis que se mostrou duas vezes mais largo na porção anterior. O estômago apresentou pregas, no entanto não foi possível confirmar um padrão específico, já que houve muita variação de forma e espessura das pregas, e o intestino também se manteve semelhante para todas as espécies.

A papila anal em relação ao tamanho do filamento branquial mostrou-se com diferentes proporções entre as espécies, em $D$. verrucosa a papila apresentou cerca de 1/6 do tamanho dos filamentos branquiais, em $D$. januarii cerca de $2 / 3$ do tamanho dos filamentos. Em D. bovena cerca de $1 / 4$ do tamanho dos filamentos e para $D$. ilo e $D$. kyolis essa proporção foi de aproximadamente $1 / 3$.

O sistema reprodutor em todas as espécies manteve o padrão triaulico, com três aberturas: vagina, pênis e ovitudo, e um arranjo semisserial, com interligação entre o ducto uterino, receptáculo seminal, bursa copulatrix e vagina, comum para os doridídeos (Odhner, 1926; Schrödl, 2003). 
A ampola em todas as espécies manteve um padrão do formato alongado e tubular. Porém diferem-se na largura e comprimento, em $D$. verrucosa a ampola é aproximadamente do mesmo tamanho e cerca de $1 / 3$ mais larga do que em $D$. januarii. D. bovena e D. kyolis apresentam a ampola semelhante à de $D$. januarii e $D$. ilo a ampola mostrou-se com cerca de $2 / 3$ da largura da encontrada em $D$. januarii.

D. verrucosa apresentou uma próstata glandular e com a região mais próxima do ducto deferente mais afunilada. D. januarii manteve o padrão semelhante ao encontrado em $D$. verrucosa. Para $D$. bovena e $D$. kyolis a próstata também se mostrou tubular e glandular, como em $D$. verrucosa e $D$. januarii, porém mais uniforme em toda sua extensão. $D$. ilo apresentou a próstata não glandular e aproximadamente 1/3 mais longa que D. januarii, D. bovena e D. kyolis.

O ducto deferente em $D$. verrucosa é três vezes mais curto do que em $D$. januarii. Em D. ilo o ducto deferente é, aproximadamente 1/5 mais longo do que em $D$. verrucosa. D. bovena e D. kyolis não possuem ducto deferente. Apenas D. verrucosa e D. januarii apresentaram o músculo do pênis conectado com a porção ventral do pericárdio, sendo que nas demais espécies o pênis está diretamente conectado com a próstata.

Todas as espécies apresentaram o pênis sem espinhos, em $D$. verrucosa se mostrou cerca de duas vezes mais longo do que em $D$. januarii. D. bovena e $D$. ilo apresentaram o pênis com aproximadamente 1/3 do comprimento e $D$. kyolis com cerca de 1/4, em comparação ao de D. verrucosa.

A gônada apresentou-se dispersa na glândula digestiva em todas as espécies, mas apenas em $D$. kyolis foi possível visualizar a diferença de coloração e textura entre a gônada e a glândula digestiva. 
A glândula feminina mostrou-se bem desenvolvida, exceto para $D$. verrucosa que apresentou a glândula feminina pouco desenvolvida, com aproximadamente 1/5 do tamanho da glândula feminina das outras espécies.

O oviduto apresentou diferenças apenas no tamanho proporcional em relação à glândula feminina, em $D$. verrucosa o oviduto mostrou-se com cerca de $1 / 3$ do tamanho da glândula feminina, $D$. januarii e $D$. ilo com cerca de $1 / 5, D$. bovena com aproximadamente $1 / 6$ e $D$. kyolis com cerca de 1/8 do tamanho da glândula feminina.

O ducto uterino em $D$. verrucosa mostrou-se curto e de difícil visualização, já em $D$. januarii mostrou-se praticamente com duas vezes o tamanho do anterior. Para $D$. bovena, $D$. ilo e $D$. kyolis o ducto apresentou-se $1 / 3$ maior no comprimento do que em D. januarii.

O arranjo, do ducto uterino, seguido do receptáculo seminal, bursa copulatrix e vagina, manteve-se semelhante para todas as espécies, variando no tamanho e na largura entre o receptáculo seminal e a bursa copulatrix. Em D. verrucosa essas estruturas mantiveram o mesmo tamanho, porém com formato piriforme para o receptáculo e arredondado para a bursa. D. januarii manteve o formato das estruturas semelhantes aos de $D$. verrucosa, porém com o receptáculo com aproximadamente $1 / 4$ do tamanho da bursa. Já em $D$. bovena o receptáculo e bursa apresentaram formato arredondado e tamanho similar. D. ilo apresentou as duas estruturas com mesmo formato piriforme do visualizado em $D$. verrucosa, no entanto apresenta o receptáculo com cerca de $1 / 2$ do tamanho da bursa. D. kyolis apresentou o mesmo formato para o receptáculo e a bursa copulatrix como $D$. verrucosa, porém com o receptáculo com cerca $1 / 2$ do tamanho da bursa.

A vagina de $D$. verrucosa e $D$. januarii assemelha-se em comprimento e largura, como descrito acima. D. bovena, D. ilo e $D$. kyolis apresentaram a vagina com cerca de 
$1 / 3$ da largura e aproximadamente $1 / 2$ do comprimento daquela vista nas duas outras espécies.

No sistema nervoso a diferença apareceu na comissura pediosa, que para os exemplares de D. verrucosa se mostrou simples e curta, como visto por Hancock \& Emblenton (1852), porém diferente do descrito por Valdés (2002), que mostrou a comissura pediosa com uma pequena bifurcação na inserção com os gânglios pediosos (Fig. 30). Para D. januarii a comissura pediosa apresentou-se dupla em toda sua extensão e aproximadamente duas vezes mais longo do que em D. verrucosa (Fig. 57). Em $D$. bovena a comissura pediosa apresentou-se curta como em $D$. verrucosa, porém dupla, sendo a externa cerca de duas vezes mais fina que a interna e aproximadamente seis vezes mais curta que a de D. januarii (Fig. 84). D. ilo e D. kyolis apresentaram a comissura pediosa curta e simples (Fig. 111), como em D. verrucosa, mas em D. kyolis a comissura mostrou-se mais parecida em tamanho (Fig. 138), com a presente em $D$. bovena.

Doris verrucosa e D. januarii apresentam a glândula de sangue única cobrindo todo o complexo nervoso (Fig. 13 e 43) (Wägele \& Willan, 2000; Valdés, 2002). Já Doris bovena, D. ilo e D. kyolis apresentaram a glândula de sangue dividida em duas partes cobrindo parcialmente o sistema nervoso (Figs. 71, 98 e 125), como típico da família Discodorididae (Dayrat, 2010).

Confirmando as descrições originais, as espécies-alvo desse trabalho apresentam diferenças morfológicas suficientes para separação específica. 


\section{CONCLUSÕES}

A partir das análises morfológicas comparativas pode-se concluir:

1. As espécies estudadas apresentaram um conjunto de características morfológicas, que corroboram com a classificação tradicional proposta, para o gênero Doris, tais como: dorso coberto por numerosos tubérculos arredondados, tubérculos menores protegendo a cavidade rinoforal e branquial, prolongamentos laterais do tegumento ao redor da boca, borda do pé sulcada horizontalmente com ausência de uma fenda longitudinal, rádula sem o dente raquidiano e pênis e vagina desprovidos de ganchos ou espinhos.

2. De acordo com a análise comparativa realizada neste trabalho, os exemplares analisados de Doris verrucosa, a princípio com distribuição anfiatlântica, apresentaram diferenças anatômicas no odontóforo, sistema reprodutor e sistema nervoso, principalmente na comissura pediosa, plausíveis para a separação em duas espécies, mantendo Doris verrucosa para a espécie da costa Atlântica da Europa e Mar Mediterrâneo, e Doris januarii (Bergh, 1878) para a costa Atlântica do Brasil.

3. Ainda há necessidade de analise de material, de Doris verrucosa, proveniente da costa Atlântica Norte Americana e da costa Atlântica Africana, a fim de se confirmar essa possível ocorrência de D. verrucosa.

4. Foram encontradas características anatômicas que permitem diferenciar as seguintes espécies: Doris verrucosa, Doris januarii, Doris bovena, Doris ilo e Doris kyolis.

5. As análises comparativas de todos os sistemas e órgãos tiveram eficiência na diferenciação de táxons muito próximos. 


\section{REFERÊNCIAS BIBLIOGRÁFICAS}

Agudo-Padrón, I., Bleicker, M. S. \& Saalfeld, K. 2009. Recent marine molluscs of Santa Catarina State, SC, Southern Brazil region: a comprehensive synthesis and check list. Visaya 1-17.

Amaral, A. C. Z., Migotto, A. E., Turra, A. \& Schaeffer-Novelli, Y. 2010. Araçá: biodiversidade, impactos e ameaças. Biota Neotropica 10(1): 219-264.

Ávila, C. 1995. Natural products of opisthobranch mollusks: a biological review. Oceanography and Marine Biology, an Annal Review 33: 487-559.

Baba K. 1998. Anatomical review of Archidoris tricolor (Baba, 1938) (Opisthobranchia: Nudibranchia: Dorididae) with the description of a new species from Japan. Venus 57:155-160.

Bergh R. 1878a. Malacologische Untersuchungen. In: Semper C, ed. Reisen im Archipel der Philippinen, theil 2, heft 13. Wiesbaden: Kreidel, 547-602, plates $62-65$

Bergh R. 1891. Die cryptobranchiaten Dorididen. Zoologische Jahrbücher, Abteilung für Systematik, Geographie und Biologie der Tiere 6: 103-144.

Bergh R. 1884a. Malacologische Untersuchungen. In: Semper C, ed. Reisen im Archipel der Philippinen, theil 3, heft 15. Wiesbaden: Kreidel, 647-754, plates $69-76$.

Bergh R. 1884b. Report on the Nudibranchiata, pp. 1-154, plates 1-14. In: Thompson CW, Murray JM, eds. Reports of the Scientific Results of the Voyage of H.M.S. 
Challenger During the Years 1873-76 Under the Command of Captain George S Nares, R.N., F.R.S. and Captain Frank Tourle Thompson, R.N. Zoology, Vol. 10. London: HMSO.

Bergh R. 1889. Malacologische Untersuchungen. In: Semper C, ed. Reisen im Archipel der Philippinen, theil 3, heft 16. Wiesbaden: Kreidel, 815-872, plates 82-84.

Bergh R. 1890. Malacologische Untersuchungen. In: Semper C, ed. Reisen im Archipel der Philippinen, theil 3, heft 17. Wiesbaden: Kreidel, 873-991, plates 85-89.

Bergh R. 1891. Die cryptobranchiaten Dorididen. Zoologische Jahrbücher, Abteilung für Systematik, Geographie und Biologie der Tiere 6: 103-144.

Bergh R. 1894. XIII. Die Opisthobranchen. Reports of the dredging operations off the West coast of Central America to the Galapagos, to the West coast of Mexico, and in the Gulf of California, in charge of Alexander Agassiz, carried on by the U. S. Fish Commission Steamer 'Albatross', during 1891, Lieut. Commander Z. L. Tanner, U.S.N., commanding. Bulletin of the Museum of Comparative Zoölogy 25: 125-233, plates 1-12.

Bergh R. 1898. Die Opisthobranchier der Sammlung Plate. Zoologische Jahrbucher, Supplement 4: 481-582, plates 28-33.

Bielecki, J-P. 2002. Doris verrucosa from Mediterranean France. Sea Slug Forum. Australian $\quad$ Museum, Sydney. Disponível em: http://www.seaslugforum.net/find/7198. [03/08/2012]. 
Bouchet, P. \& Valdés, A. 2000. Doris verrucosa Linnaeus, 1758 (Mollusca, Gastropoda): proposed conservation of the generic and specific names by designation of a neotype. Bulletin of Zoological Nomenclature. 57:74-80.

Bouchet, P. \& Rocroi, J. P. 2005. Classification and Nomenclator of Gastropod Families. Malacologia, 47(1-2):1-397.

Cimino, G., Fontana, A. \& Gavignin, M. 1999. Marine opisthobranch molluscs: chemistry and ecology in Sacoglossans and dorids. Current Organic ChemistryI 3: 327-372.

Cuvier, G. L. 1804. Memoire sur le genre Doris. Annales du Muséum d'Histoire Naturalle. 4: 447-472.

Delle Chiaje, S. 1841. Descrizione e notomia degli animali invertebrate della Sicilia Citeriore osservati vivi negli anni 1822-1830. Vol. 2 (Molluschi, Gasteropedi), 87 pp. Batelli, Napoli.

Edmunds, M. \& Just. H. 1985. Dorid, dendronotid and arminid nudibranchiate Mollusca from Barbados. Journal of Molluscan Studies 51(1): 52-63.

Eliot, C. N. 1906a. Notes on some British nudibranchs. Journal of the Marine Biological Association of the United Kingdom 7: 333-382, plates 11-12.

Eliot, C. 1910. A monography of the British Nudibranchiate Mollusca: with figures of the species, part 8 (suppl.). 198 pp., 8 pls. The Ray Society, London.

Fischer P. 1867. Catalogue des Nudibranches et Céphalopodes des côtes océaniques de la France. Journal de Conchyliologie 3 (15): 5-15. 
Fischer P. 1872. Catalogue des Nudibranches et Céphalopodes des côtes océaniques de la France (2ème Supplément). Journal de Conchyliologie 3 (20): 5-26.

Fischer P. 1880-1887. Manuel de conchyliologie et de paléontologie conchyliologique ou histoire naturelle des mollusques vivants et fossiles siuvi d'un appendice sur les brachiopods par D. P. OEhlert. Paris: F. Savy, 23 plates, pp. 1-112 [1880], pp. 113-305 [1881], pp. 305-416 [1882], pp. 417-608 [1883], pp. 609-688 [1884], pp. 689-896 [1885], pp. 897-1008 [1886], pp. 1009-1369 [1887].

Franc, A. 1968. Mollusques, gastéropodes et scaphopodes. In: Grassé P, ed. Traité de Zoologie Anatomie, Systématique, Biologie, Vol. 5. Paris: Masson, 608-893.

Franz, D. 1970. The distribution of the nudibranch Doris verrucosa Linne in the Northwest Atlantic. The Nautilus 83: 80-85.

Gadzikiewicz W. 1907. Das plötzliche Auftreten einer vergleichsweise grossen Zahl von Dorididae cryptobranchoatae (Staurodoris brobetzkii n. sp.) in den Meeresbuchten bei Sebastopol. Biologisches Centralblatter 27: 508-510.

Garciá, F. J. \& Garciá-Gómez, J. C. 1990. Anatomy of the circulatory system of the nudibranch Platydoris argo (Linné, 1767) with comparisons among Doridacea (Gastropoda: Opishtobranchia). The Veliger 33(2):166-173.

Garcia. F. J. G.; Álvares, M. D. \& Troncoso, J. S.. 2008. Opisthobranquios de Brasil. Discripción y distribución de opistobranquios del litoral de Brasil y del Arquipiélago Fernando de Noronha. Feito, S.L., Vigo, Spain. 215 pp.

Gosliner, Terrence M. and David W. Behrens. 1990. Special Resemblance, Aposematic Coloration and Mimicry in Opishtobranch Gastropods. In 
Adaptive Coloration in Invertebrates: Proceedings of a Symposium by the American Society of Zoologists. M. Wicksten (Ed.) Texas A\&M Univ. Sea Grant Program. TAMU-SG-90-106.

Gray JE. 1847. A list of the genera of recent Mollusca, their synonyma and types. Proceedings of the Zoological Society of London 15: 129-219.

Hancock, A. 1864. On the structure and homologies of the renal organ in the Nudibranchiate Mollusca. Philosophical Transactions of the Royal Society of London. Vol. V: 511-533.

Hancock, A. \& Emblenton, D. 1852. On the anatomy of Doris. Philosophical Transactions of the Royal Society of London 142: 207-252.

Ihering, H. von 1886. Zur Kenntniss der Nudibranchen der brasilianischen Küste. Jahrbücher der Deutschen Malakozoologischen Gesellschaft 13: 223-240.

Iredale T, O'Donoghue CH. 1923. List of British nudibranchiate Mollusca. Proceedings of the Malacological Society of London 15: 195-233.

Kay, E. A. \& Young, D. K. 1969. The Doridacea (Opisthobranchia; Mollusca) of the Hawaiian Islands, Pacific Science 23: 172-231.

Linnaeus, C. 1758. Systema Naturae, Ed. 10, Vol. 1.824 pp. Holmiae: Salvii.

Linnaeus, C. 1767. Systema Naturae, Ed. 12, vol. 1. 1327 pp. Holmaie: Salvii.

Marcus, E. 1955. Opisthobranchia from Brazil. Boletim da Faculdade de Filosofia, Ciências e Letras da Universidade de São Paulo, Zoologia 20: 89-261, plates $1-30 \mathrm{pp}$. 
Marcus E. 1958. Notes on Opisthobranchia. Boletim do Instituto Oceanográfico 7: 3178 , plates $1-8$.

Marcus, E. 1977. An annotated checklist of the Western Atlantic warm water opisthobranchs. Journal of Molluscan Studies (4): 1-22.

Marcus, E. 1972. Notes on Some Opisthobranch Gastropods from the Chesapeake Bay. Chesapeake Science 13(4): 300-317.

Marcus E. \& Marcus E. 1963. Opisthobranchs from the Lesser Antilles. Studies on the Fauna of Curaçao and Other Caribbean Islands 19: 1-76.

Marcus, E. \& Marcus, E. 1967. American Opisthobranch mollusks, part 1. Tropical American opisthobranchs. Studies in Tropical Oceanography 6: 1-256.

Marcus, E. \& Marcus, E. 1967b. Some opisthobranchs from Sapelo Island, Georgia, U.S.A. Malacologia 6(1-2):199-222 pp.

Marcus, E. \& Marcus, E. 1970. Opisthobranchs from Curaçao and faunistically related regions. Studies on the Fauna of Curaçao and other Caribbean Islands 122:1-129.

Odhner N. 1926. Die Opisthobranchien. In: Odhner N, ed. Further Zoological Results of the Swedish Antarctic Expedition 1901-03, Vol. 2. Stockholm: Norstedt and Söner, 1-100, plates 1-3.

Odhner, N. H. 1934. The Nudibranchiata. British Antarctic ('Terra Nova') Expedition, 1910. Natural History Report Zoology 7: 229-310, plates 1-3.

Odhner, N. H. 1939. Opisthobranchiate Mollusca from the western and northern coasts of Norway. Det Kongelige Norske Videnskabernes Selskabs Skrifter 1: 1-93. 
Orbigny, A. d'. 1839. Mollusques. Pp.1-72 in Mollusques, Equinodermes, Foraminifères et Polypiers. Vol. 2, part. 2 in Webb, P. B. \& Berthelot, S. (Eds.), 1835-1850, Histoire Naturalles des îles Canaries. Paris.

Pelseneer P. 1906. Mollusca. In: Lankester ER, ed. A Treatise on Zoology, Part 5. London: Black.

Pennant, T. 1777. British Zoology, vol. 4. 380 pp. Wilkie \& Robinson, London.

Phillippi, R. A. 1836. Enumeratio molluscorum Siciliae cum viventium tum in tellure tertiaria fossilium quae in itinere suo observaviti. 303 pp., 28 pls. Schropp, Berlin.

Pola, M., Cervera, J. L. \& Gosliner, T. M. 2007. Phylogenetic relationships of Nembrothinae (Mollusca: Doridacea: Polyceridae) inferred from morphology and mitochondrial DNA. Molecular Phylogenetics Evolution 43: 726-742.

Pola, M. \& Gosliner, T. M. 2010. The first molecular phylogeny of cladobranchian opisthobranchs (Mollusca, Gastropoda, Nudibranchia). Molecular Phylogenetics and Evolution 56: 931-941.

Pruvot-Fol, A. 1934. Les doridiens de Cuvier publiés dans lês Annales du Muséum em 1804. Etude critique et historique. Journal de Conchyliologie (4)78: 209-261.

Rapp, W. L. 1827. Über das Molluskengeschlecht Doris und Beschreibung einiger neuer Arten desselben. Nova Acta Academiae Caesareae LeopoldinoCarolinae Germanicae Naturae Curiosorum 13: 516-522, pls. 26-27.

Rios, E.C. 1985. Seashells of Brazil. Rio Grande, RS: Museu Oceanográfico de Rio Grande, 329 pp. 102 pl. 
Rios, E.C. 1994. Seashells of Brazil. RS: Museu Oceanográfico de Rio Grande, 492 pp. $113 \mathrm{pl}$.

Rios, E.C. 2009. Compendium of Brazillian Sea Shells. 3 ed. Rio Grande. Evangraf. $676 \mathrm{pp}$.

Rosenberg, G. 2012. Malacolog 4.1.0: A Database of Western Atlantic Marine Mollusca. Disponivel em: www.malacolog.org/search.php?nameid=8597 [09/06/2012]

Rudman, W.B. 1984. The Chromodorididae (Opisthobranchia: Mollusca) of the IndoWest Pacific: a review of the genera. Zoological Journal of the Linnean Society 81(2-3):115-273 pp.

Rudman, W.B. 1998. Suborder Doridina. Pp. 990-1007 in BEESLEY, P. L. ROSS (ed.). Mollusca the Southern Synthesis. Fauna of Australia. vol. 5. CSIRO Publishing: Melbourne, Part. B viii 565-1234.

Rudman, W. B. 2009. Doris verrucosa from Mediterranean France by Dominique Horst. Sea Slug Forum. Australian Museum, Sydney. Disponível em: http://www.seaslugforum.net/find/22575 [03/08/2012].

Schmekel, L. 1968. Die Gattung Doris (Gastr. Nudibranchia) im Golf von Neapel. Pubbliccazione della Stazione Zoologica di Napoli, 36: 167-187.

Schmekel L. 1985. Aspects of evolution within the opisthobranchs. In: Trueman ER, Clark MR, eds. The Mollusca, Vol. 10 (Evolution). London: Academic Press, $221-267$. 
Schmekel, L. \& Portmann, A. 1982. Opisthobranchia des Mittelmeeres. Nudibranchia und Sacoglossa. Springer-Verlag, Berlin.

Schrödl, M. 2003. Sea Slugs of Southern South America: Systematic, Biogeography and Biology of Chilean and Magellanic Nudipleura (Mollusca: Opisthobranchia). Germany. ConchBooks. 165 pp.

Schrödl, M., Jörger, K. M., Klussmann-Kolb, A. \& Wilson, N. G. 2010. Bye Bye "Opisthobranchia"! A review on the contribution of mesopsammic sea slugs to euthyneurean systematics. Thalassas. 27 (2): 101-112.

Simone, L. R. L. 2004. Comparative morphology and phylogeny of representatives of the superfamilies of Architaenioglossans and the Annulariidae (Mollusca, Caenogastropoda). Arquivos do Museu Nacional 62:387-504.

Thompson, T. E. 1975. Dorid nudibranchs from eastern Australia (Gastropoda, Opisthobranchia). Journal of Zoology 176: 477-517.

Thompson, T.E. 1976. Biology of opisthobranch molluscs Vol. I. London: The Ray Society.

Thompson, T. E. \& Brown, G. H. 1984. Biology of Opisthobranch Molluscs, vol. 2 229 pp. The Ray Society, London.

Valdés A. 2001. Deep-sea cryptobranch dorid nudibranchs (Mollusca, Opisthobranchia) from the tropical West Pacific, with descriptions of two new genera and eighteen new species. Malacologia 43: 237-311. 
Valdés, Á. 2002. A phylogenetic analysis and systematic revision of the cryptobranch dorids (Mollusca, Nudibranchia, Anthobranchia). Zoological Journal of the Linnean Society 136: 535-636.

Valdés, Á. 2004. Phylogeography and phyloecology of dorid nudibranchs (Mollusca, Gastropoda). Biological Journal of the Linnean Society 83: 551-559.

Valdés, Á. \& Gosliner, T. M. 1999. Phylogeny of the radula-less dorids (Mollusca, Nudibranchia), with the description of a new genus and a new family. Zoologica Scripta 28: 315-360.

Valdés, Á. \& Muniain, C. 2002. Revision and taxonomic reassessment of magellanic species assigned to Anisodoris Bergh, 1898 (Nudibranchia: Doridoidea). Journal of Molluscs Studies 68:345-351.

Valdés, A.; Hamann, J.; Behrens, D.W. \& Dupont, A. 2006. Caribbean Sea Slugs. Washington: Sea Challengers Natural History Books, Etc., 289 p.

Wägele, H. 1990. Revision of the genus Austrodoris Odhner, 1926 (Gastropoda, Opisthobranchia). Journal of Molluscan Studies 56: 163-180.

Wägele, H. 2004. Potential key characters in Opisthobranchia (Gastropoda, Mollusca) enhancing adaptative radiation. Organisms Diversity \& Evolution 4: 175-188.

Wägele, H. \& Klussmann-Kolb, A. 2005. Opisthobranchia (Mollusca, Gastropoda) more than just slim slugs. Shell reduction and its implications on defence and foraging. Frontiers in Zoology 2 (3): 1-18.

Wägele, H. \& Willan, R. C. 2000. Phylogeny of the Nudibranchia. Zoological Journal of the Linnean Society 130: 83-181. 
Wägele, H., Klussmann-Kolb, A., Vonnemann, V. \& Medina, M. 2008. Heterobranchia I. Pp. 469 in: Ponders, W. F. \& Lindberg, D. R. (Ed.). Phylogeny and Evolution of the Mollusca. University of California Press 385408.

Willan, R. C. 1998b. Order Nudibranchia. Pp. 990 in BEELEY, P.L. ROSS (ed.). Mollusca the Southern Synthesis. Fauna of Australia. vol. 5. CSIRO Publishing: Melbourne, Part. B viii 565-1234.

Willan, R.C. \& Coleman, N. 1984. Nudibranchs of Australasia. Australasian Marine Photographic Index, Caringbah, Sydney. 